\title{
Summary of Suspended-Solids Concentration Data, San Francisco Bay, California, Water Year 1996
}

By Paul A. Buchanan and David H. Schoellhamer

U.S. GEOLOGICAL SURVEY

Open-File Report 98-175

$\frac{n}{8}$

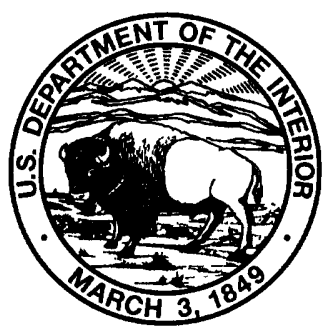




\title{
U.S. DEPARTMENT OF THE INTERIOR BRUCE BABBITT, Secretary
}

\author{
U.S. GEOLOGICAL SURVEY
}

Thomas J. Casadevall, Acting Director

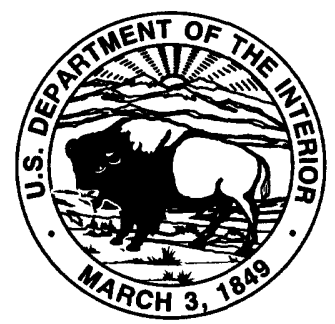

The use of firm, trade, and brand names in this report is for identification purposes only and does not constitute endorsement by the U.S. Geological Survey

For additional information write to:

\section{District Chief}

U.S. Geological Survey

Placer Hall, Suite 2012

$6000 \mathrm{~J}$ Street

Sacramento, California 95819-6129
Copies of this report can be purchased from:
U.S. Geological Survey
Information Services
Box 25286
Federal Center
Denver, CO 80225 


\section{CONTENTS}

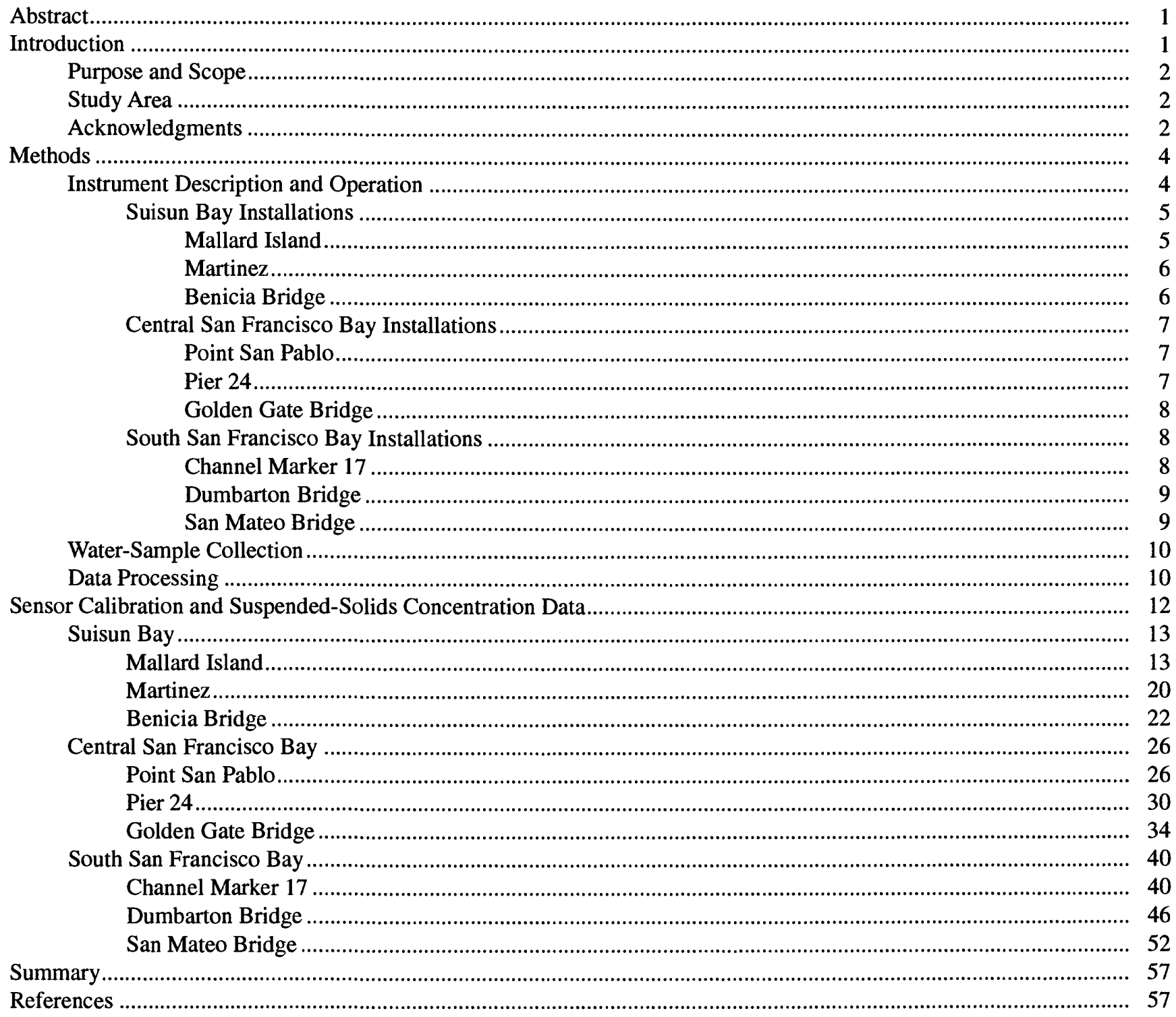

\section{FIGURES}

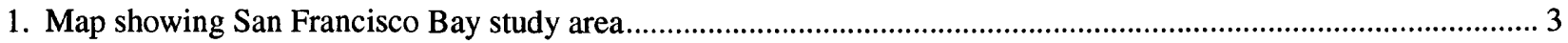

2-41. Graphs showing:

2. Raw and edited optical backscatterance data, mid-depth sensor, Point San Pablo, Central San Francisco Bay, water year 1994

3. Calibration of the near-surface optical backscatterance sensor at Mallard Island, Suisun Bay, water year 1996

4. Results of comparison test of optical backscatterance sensors (with and without wiper) conducted from December 22, 1995, through February 1, 1996, at Mallard Island, Suisun Bay, water year 1996 
5. Calibration of near-surface optical backscatterance sensor (with wiper) at Mallard Island, Suisun Bay, water year 1996

6. Calibration of near-bottom optical backscatterance sensor (with wiper) at Mallard Island, Suisun Bay, water year 1996.

7. Time series of near-surface suspended-solids concentration calculated from sensor readings at Mallard Island, Suisun Bay, water year 1996

8. Time series of near-bottom suspended-solids concentration calculated from sensor readings at Mallard Island, Suisun Bay, water year 1996

9. Calibration of near-surface optical backscatterance sensor (with wiper) at Martinez, Suisun Bay, water year 1996

10. Time series of near-surface suspended-solids concentration calculated from sensor readings at Martinez, Suisun Bay, October through January, water year 1996

11. Calibration of near-surface optical backscatterance sensor at Benicia Bridge, Suisun Bay, water year 1996

12. Calibration of near-bottom optical backscatterance sensor at Benicia Bridge, Suisun Bay, water year 1996

13. Time series of near-surface suspended-solids concentration calculated from sensor readings at Benicia Bridge, Suisun Bay, May through September, water year 1996

14. Time series of near-bottom suspended-solids concentration calculated from sensor readings at Benicia Bridge, Suisun Bay, May through September, water year 1996.

15. Calibration of mid-depth optical backscatterance sensor at Point San Pablo, Central San Francisco Bay, water year 1996

16. Calibration of near-bottom optical backscatterance sensor at Point San Pablo, Central San Francisco Bay, water year 1996

17. Time series of mid-depth suspended-solids concentration calculated from sensor readings at Point San Pablo, Central San Francisco Bay, water year 1996

18. Time series of near-bottom suspended-solids concentration calculated from sensor readings at Point San Pablo, Central San Francisco Bay, water year 1996.

19. Calibration of mid-depth optical backscatterance sensor at Pier 24, Central San Francisco Bay, water year 1996

20. Calibration of near-bottom optical backscatterance sensor at Pier 24, Central San Francisco Bay, water year 1996

21. Time series of mid-depth suspended-solids concentration calculated from sensor readings at Pier 24, Central San Francisco Bay, water year 1996

22. Time series of near-bottom suspended-solids concentration calculated from sensor readings at Pier 24, Central San Francisco Bay, water year 1996

23. Calibration of mid-depth optical backscatterance sensor at Golden Gate Bridge, Central San Francisco Bay, January 10-24, water year 1996

24. Calibration of mid-depth optical backscatterance sensor at Golden Gate Bridge, Central San Francisco Bay, February 16 through March 14, water year 1996.

25. Calibration of mid-depth optical backscatterance sensor at Golden Gate Bridge, Central San Francisco Bay, April 2 through June 6, water year 1996

26. Calibration of mid-depth optical backscatterance sensor at Golden Gate Bridge, Central San Francisco Bay, June 6 through September 30, water year 1996

27. Time series of mid-depth suspended-solids concentration calculated from sensor readings at Golden Gate Bridge, Central San Francisco Bay, water year 1996.

28. Calibration of mid-depth optical backscatterance sensor at channel marker 17, South San Francisco Bay, October 1 through March 6, water year 1996

29. Calibration of mid-depth optical backscatterance sensor at channel marker 17, South San Francisco Bay, May 9 through September 30, water year 1996

30. Calibration of near-bottom optical backscatterance sensor at channel marker 17, South San Francisco Bay, water year 1996

31. Time series of mid-depth suspended-solids concentration calculated from sensor readings at channel marker 17, South San Francisco Bay, water year 1996. 
32. Time series of near-bottom suspended-solids concentration calculated from sensor readings at channel marker 17, South San Francisco Bay, water year 1996

33. Calibration of mid-depth optical backscatterance sensor at Dumbarton Bridge, South San Francisco Bay, October 12 through April 25, water year 1996

34. Calibration of mid-depth optical backscatterance sensor at Dumbarton Bridge, South San Francisco Bay, June 18 through September 30, water year 1996

35. Calibration of near-bottom optical backscatterance sensor at Dumbarton Bridge, South San Francisco Bay, water year 1996

36. Time series of mid-depth suspended-solids concentration calculated from sensor readings at Dumbarton Bridge, South San Francisco Bay, water year 1996

37. Time series of near-bottom suspended-solids concentration calculated from sensor readings at Dumbarton Bridge, South San Francisco Bay, water year 1996

38. Calibration of mid-depth optical backscatterance sensor at San Mateo Bridge, South San Francisco Bay, water year 1996

39. Calibration of near-bottom optical backscatterance sensor at San Mateo Bridge, South San Francisco Bay, water year 1996

40. Time series of mid-depth suspended-solids concentration calculated from sensor readings at San Mateo Bridge, South San Francisco Bay, water year 1996

41. Time series of near-bottom suspended-solids concentration calculated from sensor readings at San Mateo Bridge, South San Francisco Bay, water year 1996

\section{TABLES}

1. Statistical summary of suspended-solids concentration data, Suisun Bay and Central and South

San Francisco Bays, water year 1996

2. Percentage of valid data collected by optical backscatterance sensors, Suisun Bay and Central and

South San Francisco Bays, water year 1996

CONVERSION FACTORS, VERTICAL DATUM, ABBREVIATIONS, AND ACRONYMS

\begin{tabular}{rcl}
\hline \multicolumn{1}{c}{ Multiply } & By & \multicolumn{1}{c}{ To obtain } \\
\hline inch (in.) & 25.40 & millimeter \\
foot (ft) & .3048 & meter \\
foot per second (ft/s) & .3048 & meter per second \\
mile (mi) & 1.609 & kilometer \\
pound (lb) & .4536 & kilogram \\
\hline
\end{tabular}

Temperature is given in degrees Celsius $\left({ }^{\circ} \mathrm{C}\right)$, which can be converted to degrees Fahrenheit $\left({ }^{\circ} \mathrm{F}\right)$ by the following equation:

$$
{ }^{\circ} \mathrm{F}=1.8\left({ }^{\circ} \mathrm{C}\right)+32 .
$$


Sea level: In this report, "sea level" refers to the National Geodetic Vertical Datum of 1929-a geodetic datum derived from a general adjustment of the first-order level nets of the United States and Canada, formerly called Sea Level Datum of 1929.

Mean lower low water $(M L L W)$ : The average of the lower low water height of each tidal day observed over the National Tidal Datum Epoch. The National Tidal Datum Epoch is the specific 19-year period (1960-1978 for values given in this report) adopted by the National Ocean Service as the official time segment over which tide observations are taken and reduced to obtain mean values.

$\begin{aligned} & \text { Abbreviations } \\ { }^{\circ} \mathrm{C} & \text { degrees Celsius } \\ \mathrm{L} & \text { liter } \\ \mu \mathrm{m} & \text { micrometer } \\ \mathrm{mg} / \mathrm{L} & \text { milligram per liter } \\ \mathrm{mL} & \text { milliliter } \\ \mathrm{mV} & \text { millivolt }\end{aligned}$

\section{Acronyms}

AC Alternating Current

ADAPS Automated Data Processing System

DC Direct Current

DWR California Department of Water Resources

GPS Global Positioning System

NOAA National Oceanic and Atmospheric

Administration

NTU Nephelometric Turbidity Units

PG\&E Pacific Gas and Electric

PVC Polyvinyl chloride

USGS U.S. Geological Survey 


\title{
SUMMARY OF SUSPENDED-SOLIDS CONCENTRATION DATA, SAN FRANCISCO BAY, CALIFORNIA, WATER YEAR 1996
}

\author{
By Paul A. Buchanan and David H. Schoellhamer
}

\section{ABSTRACT}

Suspended-solids concentration data were collected in San Francisco Bay during water year 1996 (October 1, 1995-September 30, 1996). Optical backscatterance sensors and water samples were used to monitor suspended solids at three sites in Suisun Bay, three sites in Central San Francisco Bay, and three sites in South San Francisco Bay. Sensors were positioned at two depths at most sites. Water samples were collected periodically and were analyzed for concentrations of suspended solids. The results of the analyses were used to calibrate the electrical output of the optical backscatterance sensors. This report presents the data-collection methods used and summarizes the suspended-solids concentration data collected from October 1995 through September 1996. Calibration plots and plots of edited data for each sensor also are presented.

\section{INTRODUCTION}

Sediments are an important component of the San Francisco Bay estuarine system. Bottom sediments provide the habitat for benthic organisms and are a reservoir of nutrients that contribute to the maintenance of estuarine productivity (Hammond and others, 1985). Potentially toxic substances, such as metals and pesticides, adsorb to sediment particles (Kuwabara and others, 1989; Domagalski and Kuivila, 1993). Benthic organisms can ingest these substances and introduce them into the food web (Luoma and others, 1985; Brown and Luoma, 1995).

The transport and fate of suspended sediments are important factors in determining the transport and fate of constituents adsorbed on the sediments. In Suisun Bay, the maximum concentration of suspended sediment usually marks the position of the turbidity maximum, which is a crucial ecological region in which suspended sediments, nutrients, phytoplankton, zooplankton, larvae, and juvenile fish accumulate (Peterson and others, 1975; Arthur and Ball, 1979, Kimmerer, 1992; Jassby and Powell, 1994).

Suspended sediments limit light availability in the bay, which, in turn, limits photosynthesis and primary phytosynthetic carbon production (Cloern, 1987; Cole and Cloern, 1987). Suspended sediments also deposit in ports and shipping channels, which then must be dredged to maintain navigation (U.S. Environmental Protection Agency, 1992). The U.S. Geological Survey (USGS), in cooperation with the San Francisco Regional Water Quality Control Board and the U.S. Army Corps of Engineers, is studying the factors that affect suspended-solids concentrations in San Francisco Bay. 


\section{Purpose and Scope}

This report summarizes suspended-solids concentration data collected by the USGS in San Francisco Bay during water year 1996 (October 1, 1995-September 30, 1996).

Suspended-solids concentrations were monitored at three sites in Suisun Bay, three sites in Central San Francisco Bay, and three sites in South San Francisco Bay.

Data for water year 1996 are available from the files of the USGS in Sacramento, California. This report is the latest in a series summarizing suspended-solids concentration data collected in San Francisco Bay beginning in water year 1992 (Buchanan and Schoellhamer, 1995, 1996; Buchanan and others, 1996). These data have been used by Tobin and others (1995) to study suspended-solids flux at Mallard Island in Suisun Bay, by Schoellhamer (1996) to study the factors that affect suspended-solids concentration in South San Francisco Bay, by Lacy and others (1996) to study suspended-solids flux in South San Francisco Bay, and by Schoellhamer (1997) to estimate the temporal variation of trace elements.

\section{Study Area}

In San Francisco Bay (fig. 1), tides are semidiurnal (two high and low tides per day) with a range from about $5.5 \mathrm{ft}$ in Suisun Bay, to $6.5 \mathrm{ft}$ at the Golden Gate and Central San Francisco Bay (Central Bay), to about $10 \mathrm{ft}$ in South San Francisco Bay (South Bay). The tides also have a 14-day spring-neap cycle. Typical tidal currents range from $0.6 \mathrm{ft} / \mathrm{s}$ in shallow water to more than $3 \mathrm{ft} / \mathrm{s}$ in deep channels (Smith, 1987). Winds are typically strongest during the summer when there is an afternoon onshore sea breeze. Most precipitation occurs from late autumn to early spring, and freshwater discharge into the bay is greatest in the spring as a result of runoff from snowmelt. About 90 percent of the discharge is from the Sacramento-San Joaquin River Delta, which drains the Central Valley of California (Smith, 1987).

Discharge from the delta contains 83 to 86 percent of the fluvial sediments that enter the bay (Porterfield, 1980) and determines the position of the turbidity maximum in Suisun Bay (Peterson and others, 1975; Arthur and Ball, 1979; Kimmerer, 1992; Jassby and Powell, 1994). During wet winters, turbid plumes of water from the Delta have extended into South Bay (Carlson and McCulloch, 1974). The bottom sediments are composed mostly of silts and clays in South Bay and in the shallow water (about $12 \mathrm{ft}$ or less) of Central, San Pablo, and Suisun Bays. Silts and sands are present in the deeper parts of Central, San Pablo, and Suisun Bays and in Carquinez Strait (Conomos and Peterson, 1977). Large tidal velocities, spring tides, and wind waves in shallow water all are capable of resuspending bottom sediments (Powell and others, 1989; Schoellhamer, 1996).

\section{Acknowledgments}

The authors gratefully acknowledge the U.S. Coast Guard, California Department of Transportation, California Department of Water Resources (DWR), the San Francisco Port Authority, San Francisco Regional Water Quality Control Board, the PakTank Corporation, and 
the Golden Gate Bridge, Highway and Transportation District, for their permission and assistance in establishing the monitoring sites used in this study. The Interagency Ecological Program and the USGS Toxic Substances Hydrology Program supported operation of a temporary instrument at Mallard Island during December 1995.

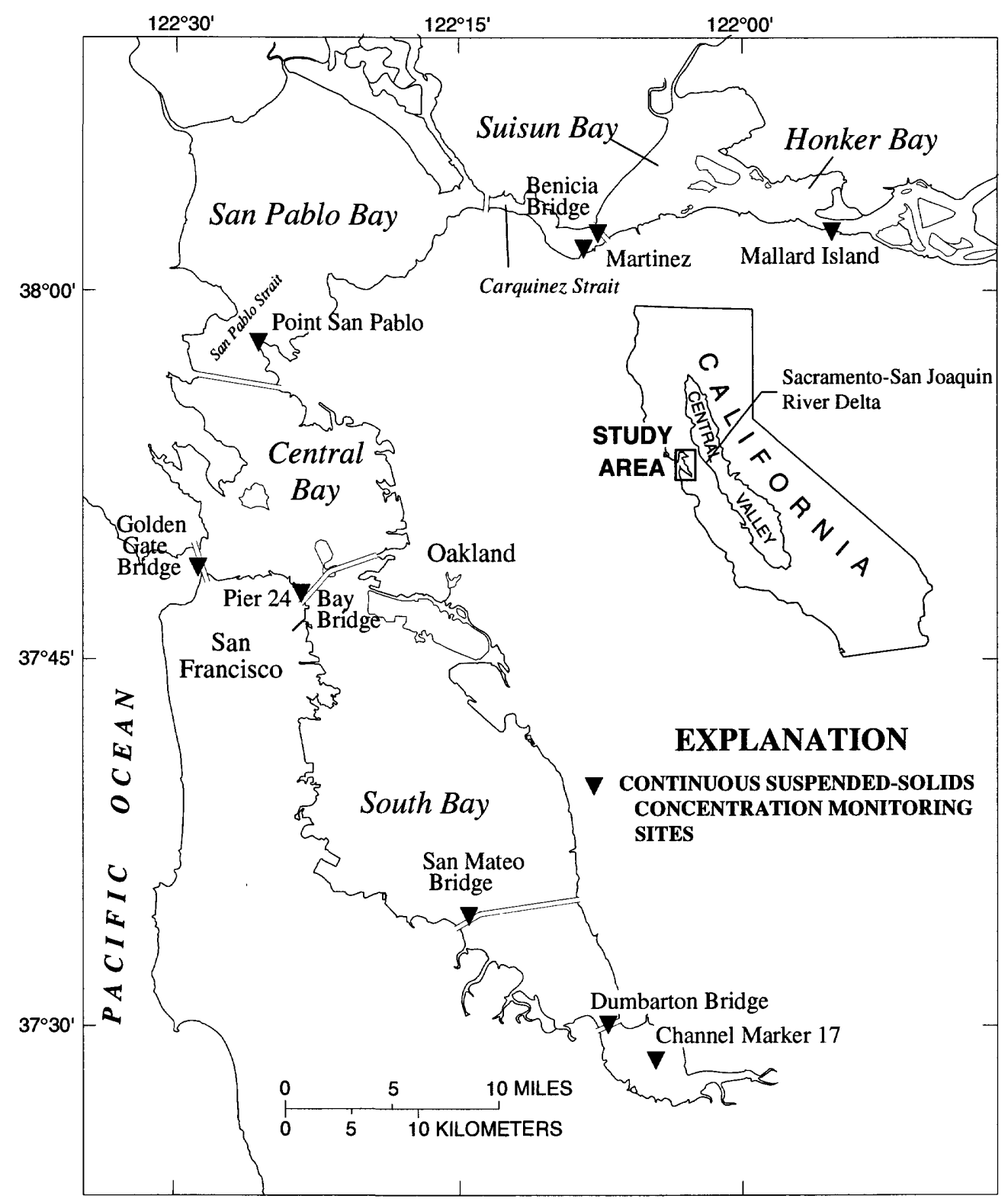

Figure 1. San Francisco Bay study area. 


\section{METHODS}

\section{Instrument Description and Operation}

Optical backscatterance sensors were used to monitor concentrations of suspended solids. An optical backscatterance sensor is a cylinder approximately $7 \mathrm{in}$. long and $1 \mathrm{in}$. in diameter with an optical window at one end, a cable connection at the other end, and an encased circuit board (Downing and others, 1981; Downing, 1983). An infrared pulse of light is transmitted through the optical window and is scattered or reflected by particles in front of the window within about 4 to 8 in. in a $165^{\circ}$ conical zone. Some of this scattered or reflected light is returned to the optical window where a receiver converts the backscattered light to a voltage output. The voltage output is proportional to the concentration of suspended solids in the water column at the depth of the sensor. Calibration of the sensor voltage output to concentrations of suspended solids will vary depending on the size and optical properties of the suspended solids; therefore, the sensors must be calibrated either in the field or in a laboratory using the same suspended material that is found in the field (Levesque and Schoellhamer, 1995).

The optical sensors were positioned in the water column using polyvinyl chloride (PVC) pipe carriages that were coated with an antifoulant paint to impede biological growth. These carriages were designed to align with the direction of flow and to ride along a stainless steel or Kevlar reinforced nylon suspension line attached to an anchor weight, which allowed the sensors to be raised and lowered easily for servicing. The plane of the optical window was positioned parallel to the direction of flow and, as the carriage and sensor moved with the changing direction of flow, the plane of the window retained its position relative to the direction of flow.

Data acquisition, data storage, and sensor timing were controlled by an electronic data logger. The logger was programmed to power the optical sensors every 15 minutes, collect data every second for 1 minute, and then average and store the output voltage for that 1-minute period. Power was supplied by 12 -volt DC, 12 -amp/hour, gel-cell batteries.

Biological growth interferes with the collection of accurate optical backscatterance data. Self-cleaning optical sensors with wipers were deployed at four sites during water year 1994 to help alleviate the problem of fouling. The self-cleaning probes are similar in size and function to the other optical sensors that are used in the study, but the self-cleaning probe has a separate electronics unit that is used to set the full-scale optical backscatter, expressed in Nephelometric Turbidity Units (NTU). The voltage output from the electronics unit is proportional to the concentration of suspended-solids in the water column at the depth of the sensor. Because the unit requires 95 to 130 -volts $\mathrm{AC}$, installation was limited to sites with $\mathrm{AC}$ power. The selfcleaning probes and electronic units were installed at two sites in Suisun Bay and at two sites in South Bay. Fouling in Suisun Bay was minor compared to that in South and Central Bays, and the self-cleaning probes were effective in keeping the optical ports clean (about 70-percent data recovery during water year 1996). However, fouling at the two sites in South Bay during the summer months was so extreme that the self-cleaning probes were often rendered ineffective by biological growth on the carriage and wiper mechanism (about 35-percent data recovery during 
water year 1995). During water year 1995, all self-cleaning probes deployed in South Bay failed because of salt crystals forming on an O-ring resulting in water leakage into the units. To address the leakage problem, a modification to the design was made by the manufacturer. In water year 1996, an updated version of the self-cleaning probe was deployed at the Dumbarton Bridge site in the South Bay and failed within the first month of operation. Thereafter, the self-cleaning probes were used only at the less saline Mallard Island site in Suisun Bay.

Optical sensors without self-cleaning wipers required frequent cleaning but, because of the difficulty in servicing some of the monitoring stations, cleaning was done every 1 to 5 (usually 3 ) weeks. Overall, about 30 percent of the collected data was invalidated by fouling. Fouling generally was greatest on the sensor closest to the water surface. However, at shallower sites where the upper sensor was set $10 \mathrm{ft}$ above the lower sensor, fouling was about equal on both sensors. Fouling would begin to affect sensor output from 2 days to several weeks after cleaning, depending on the level of biological activity in the bay. Generally, biological fouling was greatest during the spring and summer months.

\section{Suisun Bay Installations}

Suspended-solids concentration data were collected at three sites in Suisun Bay: Suisun Bay at Mallard Island, Carquinez Strait at Martinez, and Carquinez Strait at Benicia Bridge (fig. 1). Monitoring equipment was installed at the Mallard Island and Martinez sites during water year 1994, and the Benicia Bridge site was established during water year 1996.

\section{Mallard Island}

Self-cleaning optical sensors were installed at the DWR Mallard Island Compliance

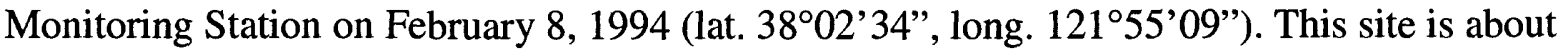
$5 \mathrm{mi}$ downstream from the confluence of the Sacramento and San Joaquin Rivers and is at the north shore of Mallard Island near the eastern boundary of Honker Bay, an embayment of Suisun Bay (fig. 1). The station was constructed in the early 1980's by DWR on Pacific Gas and Electric (PG\&E) property, and data were first recorded at the station in January 1984. A quarter-milelong wooden walkway crosses the sometimes submerged reedbeds of Mallard Island and connects the concrete block house to the levee road.

Sensors were positioned at near-bottom ( $5 \mathrm{ft}$ above the bottom) and near-surface ( $3.3 \mathrm{ft}$ below the surface) to coincide with DWR near-bottom electrical conductance and temperature sensors and near-surface pump intake. The pump intake is attached to a float housed inside a 12in. PVC pipe and draws water from about $3 \mathrm{ft}$ below the surface. DWR near-surface parameters are measured by sensors submerged in flow-through chambers inside the gage house. This configuration allows the USGS to use DWR data for parameters other than turbidity and saves the cost of installing duplicate sets of sensors. DWR also monitors stage, $\mathrm{pH}$, chlorophyll concentration, and meteorological parameters. Mean lower low water depth at this site is about $25 \mathrm{ft}$.

Data storage is controlled by a data logger connected to a cellular phone and modem. AC power is used to operate both optical sensors and to charge a 12-volt, 12-amp/hour battery that powers the data logger and modem. The instruments are housed inside the gage house. The 
sensors are suspended from a galvanized support stand attached to the metal railing on the northwest corner of the concrete deck of the station. This stand has two stainless-steel lines attached to separate concrete weights, one for the near-bottom sensor and the other for the nearsurface sensor. The near-bottom sensor is positioned in a PVC carriage suspended on the stainless-steel line by a nylon rope at the specified depth. The near-surface sensor is housed in a PVC carriage that is attached to a float. This float assembly moves up and down the suspension line during tidal cycles, which maintains the near-surface sensor at the same depth as the DWR pump intake. A pressure transducer is positioned on the float assembly at the same level as the sensor and provides data to verify the depth of the near-surface sensor. To prevent sensor cables from being snagged by debris, a counterweight was installed to keep slack cables out of the water. An auto-sampler was deployed in July and collected hourly samples over a 24-hour tidal cycle to help calibrate the near-bottom sensor.

\section{Martinez}

Self-cleaning optical sensors were installed at the DWR Martinez Compliance Monitoring Station on February 8, 1994 (lat. $38^{\circ} 01^{\prime} 40^{\prime \prime}$, long. $122^{\circ} 08^{\prime} 22^{\prime \prime}$ ). This site is at the end of the Martinez Marina fishing pier at the south shore of Carquinez Strait where the strait widens into Suisun Bay. The station was constructed in the early 1980's by DWR on City of Martinez property and data were first recorded in May 1983.

Sensors were positioned at near-bottom ( $5 \mathrm{ft}$ above the bottom) and near-surface ( $3.3 \mathrm{ft}$ below the surface) to coincide with placement of DWR sensors. Mean lower low water depth at this site is about $31 \mathrm{ft}$. Data from the near-bottom sensor are representative of local circulation patterns and a nearby mudflat. During floodtides, output from the near-bottom sensor was poorly correlated with independent optical sensor measurements made slightly north of the site (Tobin and others, 1995). The near-bottom sensor was removed on December 2, 1994. Data storage, power supplies, and installation descriptions are identical to those for the Mallard Island station with the exception that the Martinez site does not have a cellular phone or modem and the shelter and deck are wood structures.

The Martinez site was scheduled to be closed in spring 1996 because the Benicia Bridge site was considered more representative of suspended-solids concentration in Carquinez Strait. The last optical backscatterance data were collected at this site on January 18, 1996.

\section{Benicia Bridge}

Suspended-solids concentration monitoring equipment was installed March 15, 1996, at the Benicia Bridge (lat. $38^{\circ} 02^{\prime} 42^{\prime \prime}$, long. $\left.122^{\circ} 07^{\prime} 32^{\prime \prime}\right)$. This site is located on Pier 7 of the Benicia Bridge north of the main ship channel (fig. 1). The National Oceanic and Atmospheric Administration (NOAA) operates salinity sensors and an acoustic Doppler current profiler near this site. Optical sensors were deployed at near-bottom and near-surface $(25 \mathrm{ft}$ and $74 \mathrm{ft}$ above the bottom) to coincide with the elevations of the NOAA sensors. Mean lower low water depth is about $80 \mathrm{ft}$ at the north side of the pier, although the average mean lower low water depths near the pier are about $60 \mathrm{ft}$. The near-bottom sensor was set $25 \mathrm{ft}$ above the bottom to collect 
data representative of the average mean lower low water depth. The sensors are suspended between the concrete pier superstructure and the fender boards, an approximate distance of $1 \mathrm{ft}$. PVC carriages attached to 1/4-in. stainless-steel line are anchored to a 125-lb weight and are used to suspend the sensors at the desired depth.

Self-cleaning probes (the newer versions) were installed on March 15, 1996. The upper sensor failed immediately after deployment. The lower sensor failed on April 29, 1996. Sensors without the self-cleaning function were installed on May 15, 1996, and remained in operation through the end of the water year. AC power is available at this site and is used to charge a 12volt, 12-amp/hour battery that powers the data logger and sensors. The instruments are housed in a 3- by 2 - by 1 -ft weather-proof shelter mounted on the pier.

\section{Central San Francisco Bay Installations}

Suspended-solids concentration data were collected at three sites in Central San Francisco Bay during water year 1996: San Pablo Strait at Point San Pablo, Pier 24 at San Francisco, and the south tower of the Golden Gate Bridge (fig. 1).

\section{Point San Pablo}

The USGS maintains a monitoring station at San Pablo Strait on the northern end of the

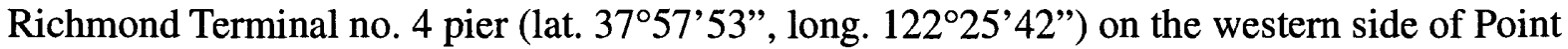
San Pablo. The USGS took over operation of this station from the DWR in October 1989. Data collected prior to October 1, 1989, can be obtained from DWR.

Optical sensors were installed at Point San Pablo on December 1, 1992, and were positioned at near-bottom and mid-depth ( $3 \mathrm{ft}$ and $13 \mathrm{ft}$ from the bottom). Mean lower low water depth at this site is about $26 \mathrm{ft}$. Specific conductance and temperature data (cooperatively funded with DWR) are collected at near-bottom and near-surface points in the water column (nearbottom and near-surface depths are sampled to define the largest stratification). Sensor timing and storage are controlled by a data logger connected to a phone line and modem. Water level is recorded using a float-driven, incremental encoder wired into the data logger, and outside water levels are read using a wire-weight gage. A separate data logger controls the optical sensors. AC power is available at this site and is used to charge a 12 -volt, 60 -amp/hour battery that powers the data loggers and sensors. The instruments are housed in a 5- by 8- by 8 - $\mathrm{ft}$ wooden shelter.

\section{Pier 24}

The monitoring station at Pier 24 is on the western end of the San Francisco-Oakland Bay Bridge (lat. $37^{\circ} 47^{\prime} 27^{\prime \prime}$, long. $122^{\circ} 23^{\prime} 05^{\prime \prime}$ ) (fig. 1). The USGS took over operation of this station from DWR in October 1989. Data collected prior to October 1, 1989, can be obtained from DWR.

Optical sensors were installed at the Pier 24 site on May 25, 1993, and were positioned at near-bottom and mid-depth ( $3 \mathrm{ft}$ and $23 \mathrm{ft}$ above the bottom). Mean lower low water depth at this site is about $41 \mathrm{ft}$. As at the Point San Pablo site, specific-conductance and temperature data 
(cooperatively funded with DWR) are collected at near-bottom and near-surface points in the water column. Sensor timing and storage are controlled by a data logger connected to a cellular phone and modem. AC power is available at this site and is used to charge two 12-volt, 12 -amp/hour batteries that power the instrumentation. The instruments are housed in a corrugated steel shelter.

\section{Golden Gate Bridge}

The monitoring station on the Golden Gate Bridge is located on the north side of the south tower fender wall (lat. $37^{\circ} 49^{\prime} 06^{\prime \prime}$, long. $122^{\circ} 28^{\prime} 18^{\prime \prime}$ ) (fig. 1). The south tower is $1,125 \mathrm{ft}$ from the San Francisco shore and marks the southern edge of the main channel. The station was initially established on October 27, 1994, but was not operational until water year 1996 because of numerous complications.

The optical sensors originally were deployed at two points in the water column ( $5 \mathrm{ft}$ and $45 \mathrm{ft}$ above the bottom). Mean lower low water depth at this site is about $75 \mathrm{ft}$ and increases to a maximum depth of $378 \mathrm{ft}$ in the main channel. The instruments are housed in a 6- by 6- by 8$\mathrm{ft}$ fiberglass shelter on the pier footing. Sensors were suspended in place using PVC carriages and Kevlar reinforced nylon line attached to a 400-lb concrete weight. A data logger and modem are used to control sensor timing, data storage, and retrieval. AC power is available at this site, and all instruments are powered by a 12 -volt, 60 -amp/hour battery with an AC/DC charger and regulator. In addition to suspended-solids concentrations, specific conductance and temperature (cooperatively funded with DWR) are monitored at near-surface depth.

Currents past the south tower are swift, especially when ebbing during a spring tide, and would lift the concrete weight out of position, resulting in damage to the suspension line and sensor cables. After much trial and error, a 600-lb railroad wheel attached to 3/8-in. stainlesssteel line was sufficient to keep the sensors in position. However, the lower sensor cables were being destroyed, probably by the remains of forming material used in the construction of the pier footing that jutted out into the water column and snagged the cables. For water year 1996, sensors were deployed at the upper position only.

\section{South San Francisco Bay Installations}

Suspended-solids concentration data were collected at three sites in South San Francisco Bay (fig. 1). Monitoring stations were installed during water year 1992 at two sites: South San Francisco Bay at channel marker 17 and South San Francisco Bay at the San Mateo Bridge. The South San Francisco Bay at Dumbarton Bridge monitoring station was installed during water year 1993.

\section{Channel Marker 17}

The southernmost monitoring site in South Bay is at the Coast Guard channel marker 17 (lat. $37^{\circ} 28^{\prime} 44^{\prime \prime}$, long. $122^{\circ} 04^{\prime} 38^{\prime \prime}$ ). Instrumentation was installed on February 26,1992 , and the optical sensors were positioned at near-bottom and mid-depth ( $3 \mathrm{ft}$ and $13 \mathrm{ft}$ from the bottom). 
Mean lower low water depth at this site is about $25 \mathrm{ft}$. Sensor cables are protected by a $10-\mathrm{ft}$ length of PVC pipe strapped to the channel marker support column. Sensor cables, carriages, and probes are suspended in the water column using a 100-lb weight attached to a 1/4-in. Kevlar reinforced nylon line. The data logger and 12 -volt, 12 -amp/hour batteries are housed in a 2 - by 2- by 1-ft weather-proof enclosure mounted on the channel marker platform.

\section{Dumbarton Bridge}

Suspended-solids concentration monitoring equipment was installed on October 21, 1992, at Pier 23 of the Dumbarton Bridge on the west side of the ship channel (lat. $37^{\circ} 30^{\prime} 15^{\prime \prime}$, long. $122^{\circ} 07^{\prime} 10^{\prime \prime}$ ) (fig. 1). Optical sensors were deployed at near-bottom and mid-depth ( $4 \mathrm{ft}$ and 23 $\mathrm{ft}$ above the bottom). Mean lower low water depth is about $45 \mathrm{ft}$. The sensors are suspended between the concrete pier superstructure and the fender boards, which are approximately $3 \mathrm{ft}$ apart. PVC carriages, attached to 1/4-in. Kevlar reinforced nylon line, are anchored to a 100-lb weight and are used to suspend the sensors at the desired depth.

The two self-cleaning probes in operation since March 17, 1994, failed during water year 1995. The inoperable equipment was removed on July 26, 1995, and replacement sensors without the self-cleaning function were installed on October 12, 1995. The mid-depth sensor failed during April 1996 and was replaced with a newer version of the wiper probe. This sensor failed within 1 month, and a replacement sensor without the self-cleaning function was deployed on June 18, 1996. An auto-sampler was deployed during June and collected hourly samples over a 24-hour tidal cycle to help calibrate the mid-depth and near-bottom sensors. AC power is available at this site and is used to charge a 12 -volt, 12 -amp/hour battery that powers the instrumentation. The instrumentation is housed in a 3- by 2 - by $1-\mathrm{ft}$ weather-proof shelter mounted on the pier.

\section{San Mateo Bridge}

The monitoring station on the San Mateo Bridge is at Pier 20 on the east side of the ship channel (lat. $37^{\circ} 35^{\prime} 04^{\prime \prime}$, long. $122^{\circ} 14^{\prime} 59^{\prime \prime}$ ) (fig. 1). This station originally was operated by DWR, but the USGS took over operations in October 1989. Data collected prior to October 1, 1989, can be obtained from DWR.

The optical sensors were installed on December 23, 1991, and were positioned at nearbottom and mid-depth ( $8 \mathrm{ft}$ and $29 \mathrm{ft}$ above the bottom during water year 1996). Mean lower low water depth at this site is about $48 \mathrm{ft}$. The instruments are housed in an 8 - by 6- by 8 -ft wooden shelter on the pier, which is surrounded by a protective fender structure. The sensors are deployed between the pier and the fender, and flow past the sensors is affected to some degree by the pilings and the concrete superstructure. Sensors are suspended in place using PVC carriages and stainless-steel line attached to a 200-lb weight. A separate data logger and modem are used to control sensor timing, data storage, and retrieval. $\mathrm{AC}$ power is available at this site and is used to charge a 12 -volt, 60 -amp/hour battery that powers the data loggers and sensors. In addition to suspended-solids concentrations, specific conductance and temperature (cooperatively funded with DWR) are monitored at near-bottom and near-surface depths. 
The self-cleaning probes that failed during water year 1995 were replaced with sensors without the self-cleaning function on November 9,1995 . The mid-depth sensor was replaced three times during water year 1996 because of malfunctions.

\section{Water-Sample Collection}

Water samples were collected using a horizontally positioned Van Dorn sampler before and after the sensors were cleaned. The Van Dorn sampler is a plastic tube with rubber stoppers at each end that snap shut when triggered by a small weight dropped down a suspension cable. The suspended-solids concentration of water samples collected with a Van Dorn sampler and a P-72 point sampler were compared and found to be virtually identical (Buchanan and others, 1996). With the optical sensors deployed, the sampler was lowered to the depth of the sensor by a reel and crane assembly and triggered while the sensor was collecting data. The water sample was then removed from the sampler, marked for identification, and placed in a cooler and chilled to limit biological growth.

An auto-sampler was used during water year 1996 to help calibrate the near-bottom sensor at Mallard Island and the mid-depth and near-bottom sensors at Dumbarton Bridge. The autosampler is a programmable peristaltic pump with 1/4-in. plastic tubing capable of collecting 24 separate samples. The auto-sampler tubing was deployed at the depth of the sensor by strapping the tubing to the sensor cables. The auto-sampler was programed to collect hourly samples while the sensor was collecting data.

Samples were sent to the USGS Sediment Laboratory in Salinas, California, for analysis to determine suspended-solids concentration. Each sample was filtered through a $0.45-\mu \mathrm{m}$ membrane filter, the filter was rinsed to remove salts, and the insoluble material was dried at $103^{\circ} \mathrm{C}$ and weighed (Fishman and Friedman, 1989). Suspended sediment is the material that settles to the bottom of the sample bottle; whereas suspended solids include suspended sediment and buoyant particles that do not settle and are trapped on the filter. The difference between suspended-solids concentration and suspended-sediment concentration for San Francisco Bay water probably is small. Suspended-solids concentration and suspended-particulate matter are identical.

\section{Data Processing}

Data loggers stored the voltage outputs from the optical sensors every 15 minutes. Recorded data were downloaded from the data logger onto a storage module during site visits by USGS personnel. Raw data from the storage modules were loaded into the USGS's Automated Data Processing System (ADAPS).

The time-series data were retrieved and edited to remove invalid data. Invalid data included rapidly increasing voltage outputs and unusually high voltage outputs of short duration. As biological growth occurred on the optical sensors, the voltage output of the sensors increased. An example time series of raw and edited data from water year 1994 is presented in 
figure 2. After the sensors were cleaned, sensor output immediately decreased (fig. 2, April 19, June 8, and June 28). Efforts to correct the invalid data proved to be unsuccessful because the desired signal was sometimes highly variable. Thus, data collected during the period prior to sensor cleaning often were unusable and were removed from the record (fig. 2). Spikes in the data, which are anomalously high voltages probably caused by debris temporarily wrapping around the sensor or by large marine organisms (fish, crabs) on or near the sensor, also were removed from the raw data record (fig. 2). Sometimes, incomplete cleaning of a sensor would cause a small constant shift in sensor output that could be corrected using water-sample data.
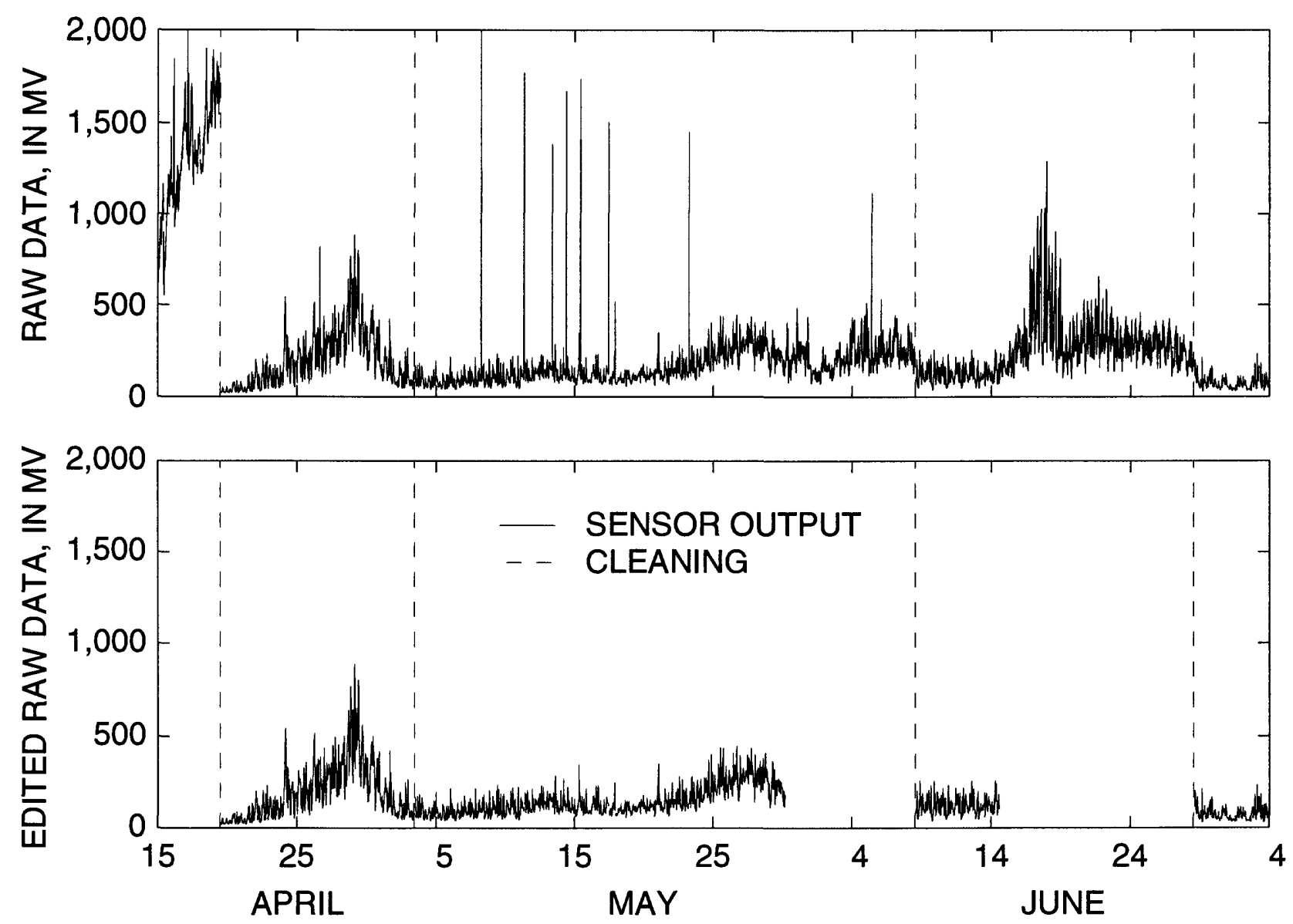

Figure 2. Raw and edited optical backscatterance data, mid-depth sensor, Point San Pablo, Central San Francisco Bay, California, water year 1994 (from Buchanan and others, 1996). 


\section{SENSOR CALIBRATION AND SUSPENDED-SOLIDS CONCENTRATION DATA}

The output from the optical sensors was converted to suspended-solids concentration using linear regression equations. A statistical summary of the calculated suspended-solids concentrations, and the percentage of valid data collected at each site is presented in tables 1 and 2 , respectively. This section also includes the linear regression plots for optical sensor output (in $\mathrm{mV}$ ) versus suspended-solids concentration (in $\mathrm{mg} / \mathrm{L}$ ). The linear regression (calibration) plots include the number of samples, correlation coefficient, squared correlation coefficient, regression significance level, and root-mean-squared error. Finally, the time-series plots of suspended-solids concentration data are shown for each site.

Table 1. Statistical summary of suspended-solids concentration data, Suisun Bay and Central and South San Francisco Bays, California, water year 1996

[All measurements are in milligrams per liter. Lower quartile is 25 th percentile; upper quartile is 75 th percentile]

\begin{tabular}{|c|c|c|c|c|c|}
\hline Site & Depth & Mean & Median & Lower quartile & Upper quartile \\
\hline \multirow[t]{2}{*}{ Mallard Island } & Near-surface & 42 & 39 & 33 & 47 \\
\hline & Near-bottom & 55 & 49 & 36 & 68 \\
\hline Martinez ${ }^{1}$ & Near-surface & 47 & 42 & 29 & 60 \\
\hline \multirow[t]{2}{*}{ Benicia $^{2}$} & Near-surface & 60 & 55 & 45 & 72 \\
\hline & Near-bottom & 130 & 120 & 86 & 170 \\
\hline \multirow{2}{*}{ Point San Pablo } & Mid-depth & 65 & 50 & 31 & 81 \\
\hline & Near-bottom & 90 & 74 & 56 & 100 \\
\hline \multirow[t]{2}{*}{ Pier 24} & Mid-depth & 29 & 23 & 12 & 40 \\
\hline & Near-bottom & 53 & 49 & 32 & 68 \\
\hline Golden Gate Bridge & Mid-depth & 20 & 19 & 14 & 25 \\
\hline \multirow[t]{2}{*}{ Channel marker 17} & Mid-depth & 110 & 71 & 35 & 160 \\
\hline & Near-bottom & 200 & 130 & 61 & 260 \\
\hline \multirow[t]{2}{*}{ Dumbarton Bridge } & Mid-depth & 120 & 89 & 45 & 170 \\
\hline & Near-bottom & 170 & 140 & 78 & 230 \\
\hline \multirow[t]{2}{*}{ San Mateo Bridge } & Mid-depth & 40 & 25 & 11 & 46 \\
\hline & Near-bottom & 47 & 41 & 20 & 66 \\
\hline
\end{tabular}

${ }^{\mathrm{T}}$ Martinez data are for the period October 1, 1995, through January 18, 1996.

${ }^{2}$ Benicia data are for the period May 14 through September 30, 1996. 
Table 2. Percentage of valid data collected by optical backscatterance sensors, Suisun Bay and Central and South San Francisco Bays, California, water year 1996

\begin{tabular}{lcc}
\hline \multicolumn{1}{c}{ Site } & Depth & Percent valid data \\
\hline Mallard Island & Near-surface & 69 \\
& Near-bottom & 72 \\
Martinez $^{1}$ & Near-surface & 69 \\
Benicia $^{2}$ & Near-surface & 62 \\
& Near-bottom & 59 \\
Point San Pablo & Mid-depth & 74 \\
& Near-bottom & 87 \\
Pier 24 & Mid-depth & 41 \\
& Near-bottom & 48 \\
Golden Gate Bridge & Near-surface & 49 \\
Channel marker 17 & Mid-depth & 45 \\
& Near-bottom & 67 \\
Dumbarton Bridge & Mid-depth & 33 \\
& Near-bottom & 45 \\
San Mateo Bridge & Mid-depth & 11 \\
& Near-bottom & 23 \\
\hline 'Martinez data are for the period October 1, 1995, through January 18, 1996. & ${ }^{2}$ Benicia data are for the period May 14 through September 30, 1996.
\end{tabular}

\section{Suisun Bay}

\section{Mallard Island}

Data were lost from October 1 to December 8, 1995, as a result of power lines being stolen by vandals in early September 1995 . Near-surface suspended-solids concentration data were collected from December 8 to 22, 1995, using an optical sensor without the self-cleaning function (powered by battery). The calibration of the temporary near-surface sensor had a standard error of $8.0 \mathrm{mg} / \mathrm{L}$ (fig. 3) and was developed using water samples collected during deployment of the sensor. AC power was restored on December 22, 1995, and the self-cleaning probes were brought back on line. From December 22, 1995, through February 1, 1996, the selfcleaning probe and the probe without the self-cleaning function were operated side by side. The suspended-solids concentrations calculated from the output of the two sensors were nearly identical (fig. 4). The two sets of water samples used to develop the calibrations of the sensors were independent of each other. Thus, the response of the two types of optical sensors is very similar, and independent calibrations of the sensors produce virtually the same suspended-solids concentration time series. Data from the self-cleaning probe are shown in figure 7 for the period of overlapping measurements. The calibration of the near-surface self-cleaning probe had a standard error of $5.7 \mathrm{mg} / \mathrm{L}$ (fig. 5) and was calibrated from samples collected from December 9 , 1994, through September 30, 1996, excluding flood samples collected from January through 
March 1995. There were about 15 days of invalid data in May because the wiper blade stopped over the optical port after a cleaning cycle. The calibration of the near-bottom sensor had a standard error of $12.0 \mathrm{mg} / \mathrm{L}$ (fig. 6) and was calibrated from samples collected from April 20, 1995, through September 30, 1996, because of a calibration shift after the flood in March 1995. Suspended-solids concentration data collected during water year 1996 are presented in figures 7 and 8.

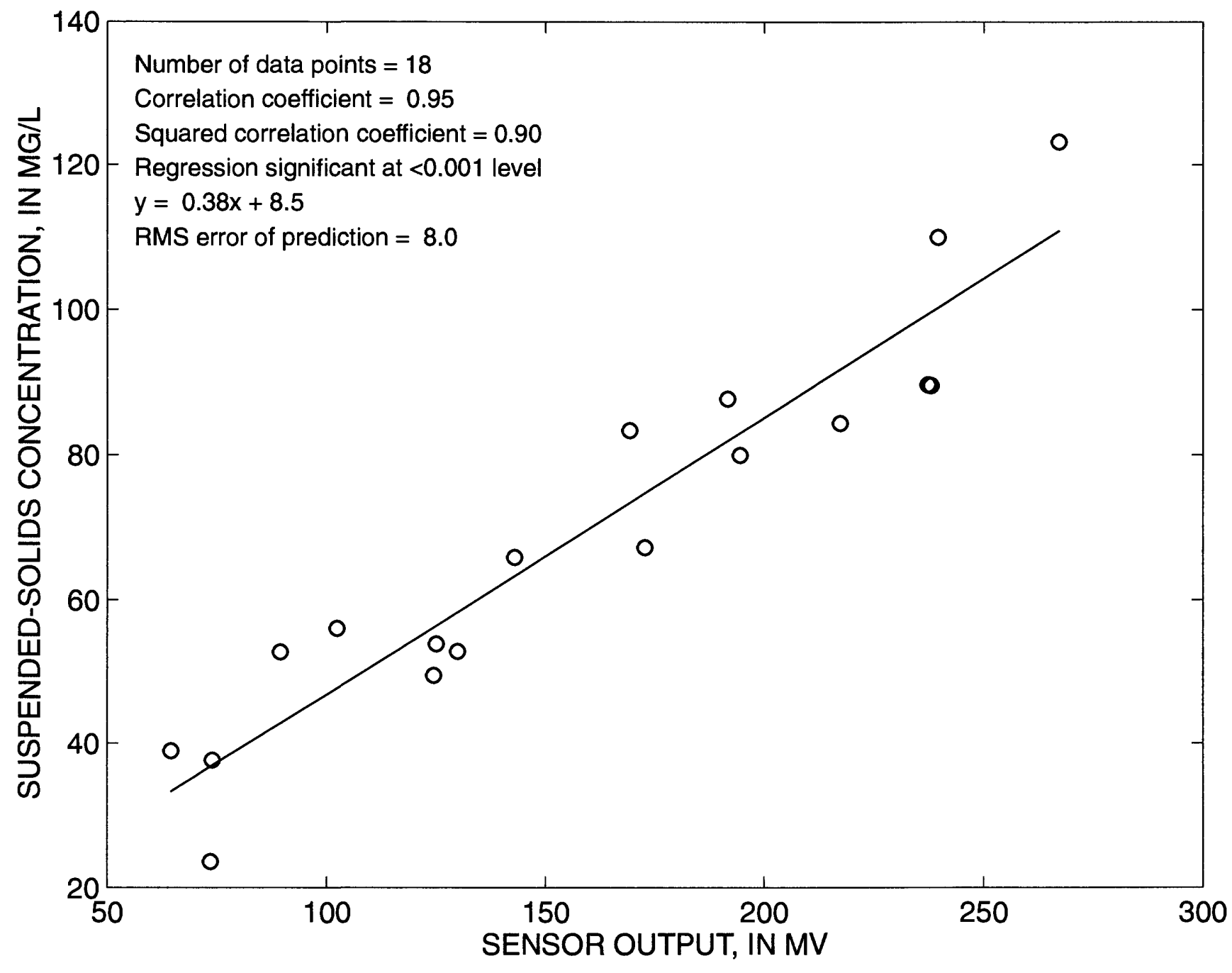

Figure 3. Calibration of the near-surface optical backscatterance sensor at Mallard Island, Suisun Bay, California, water year 1996. 


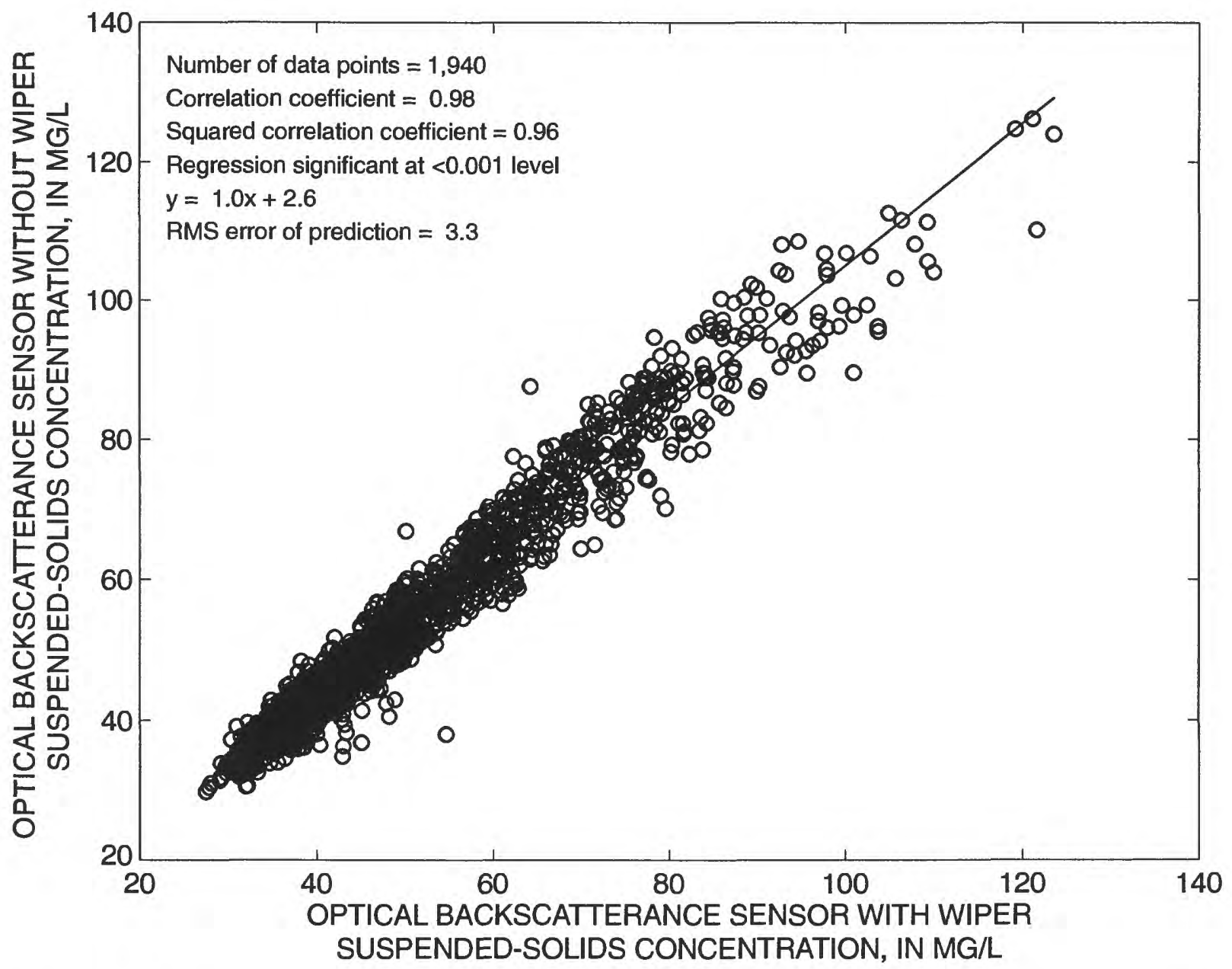

Figure 4. Results of comparison test of optical backscatterance sensors (with and without wiper) conducted from December 22, 1995, through February 1, 1996, at Mallard Island, Suisun Bay, California, water year 1996. 


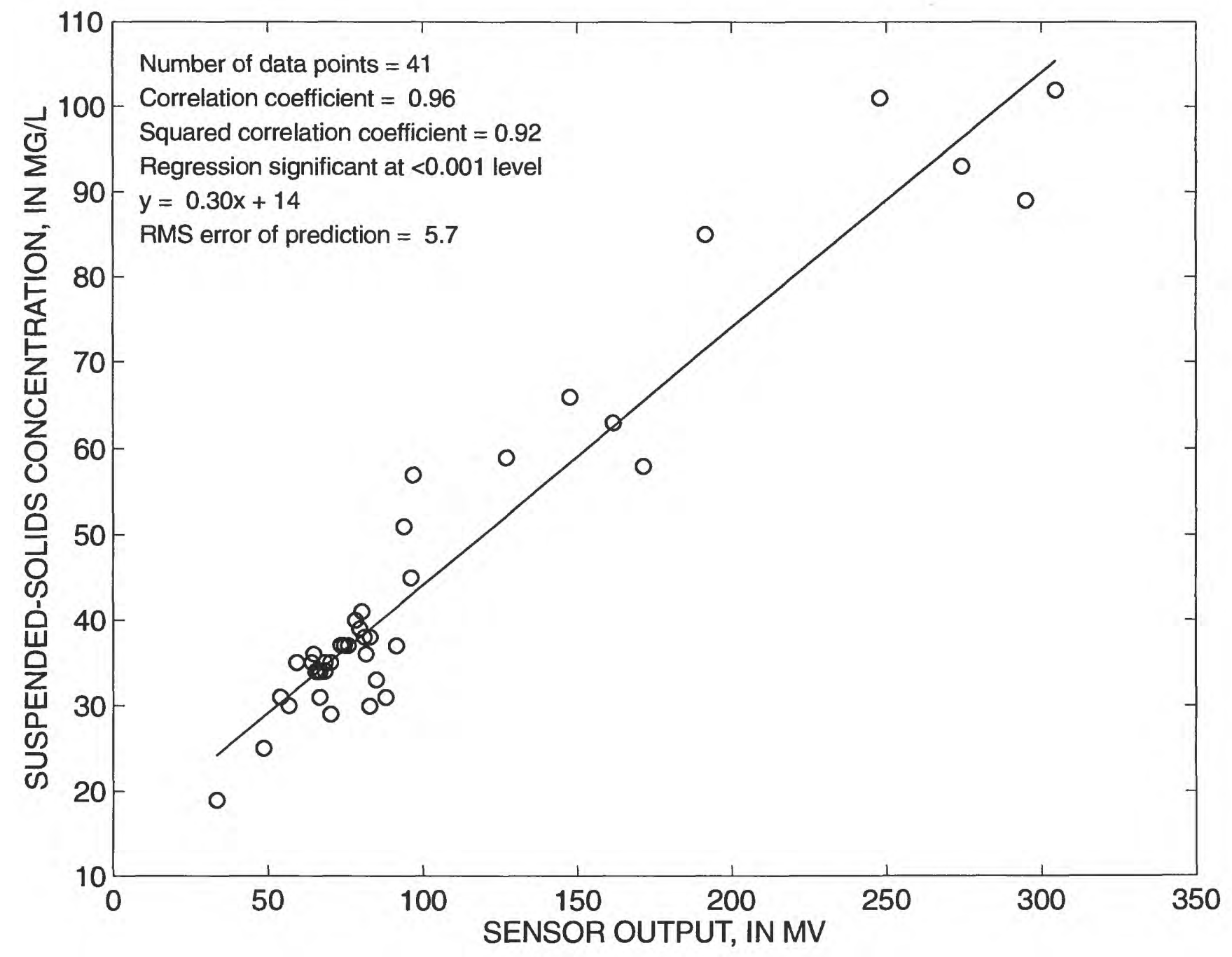

Figure 5. Calibration of near-surface optical backscatterance sensor (with wiper) at Mallard Island, Suisun Bay, California, water year 1996. 


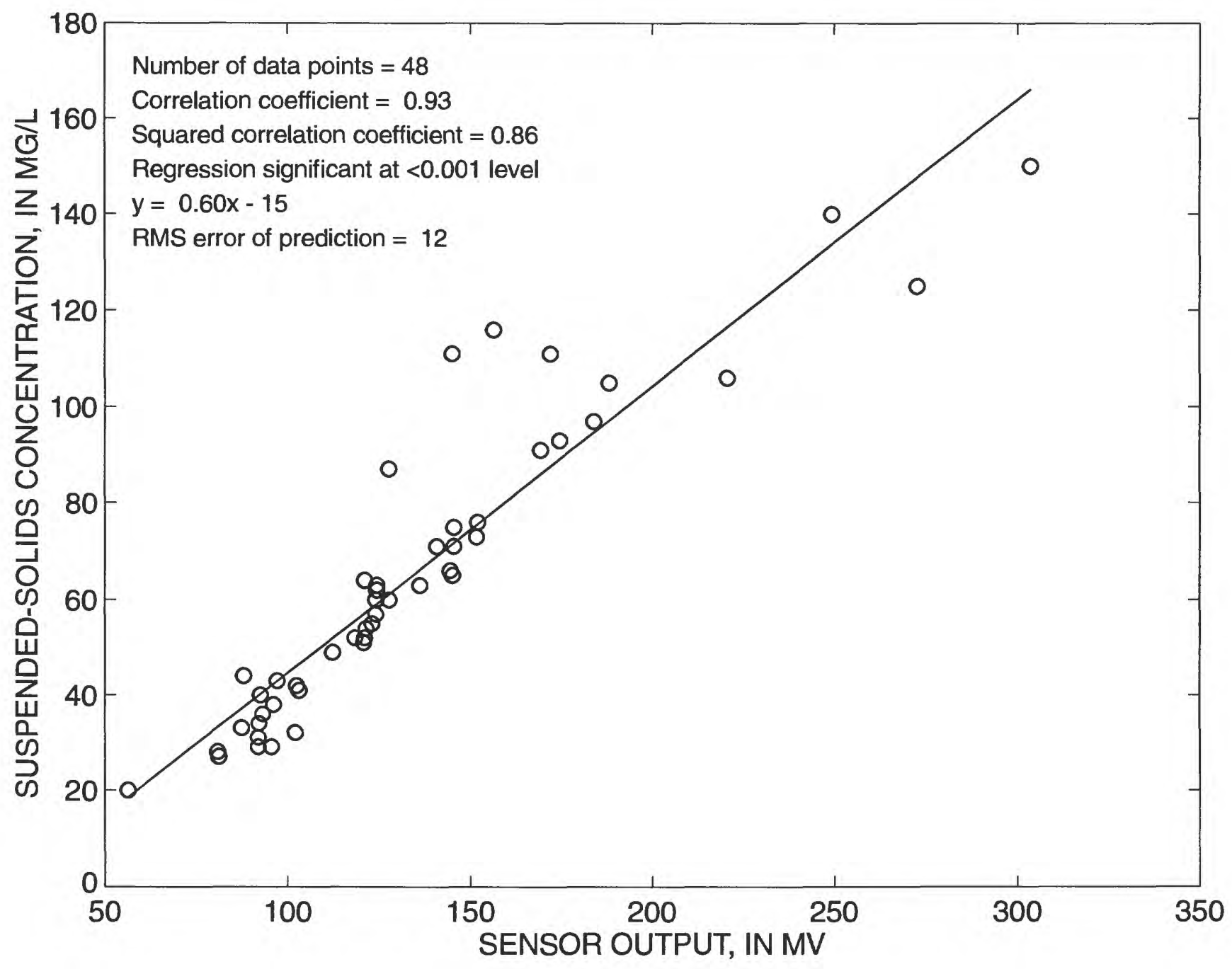

Figure 6. Calibration of near-bottom optical backscatterance sensor (with wiper) at Mallard Island, Suisun Bay, California, water year 1996. 


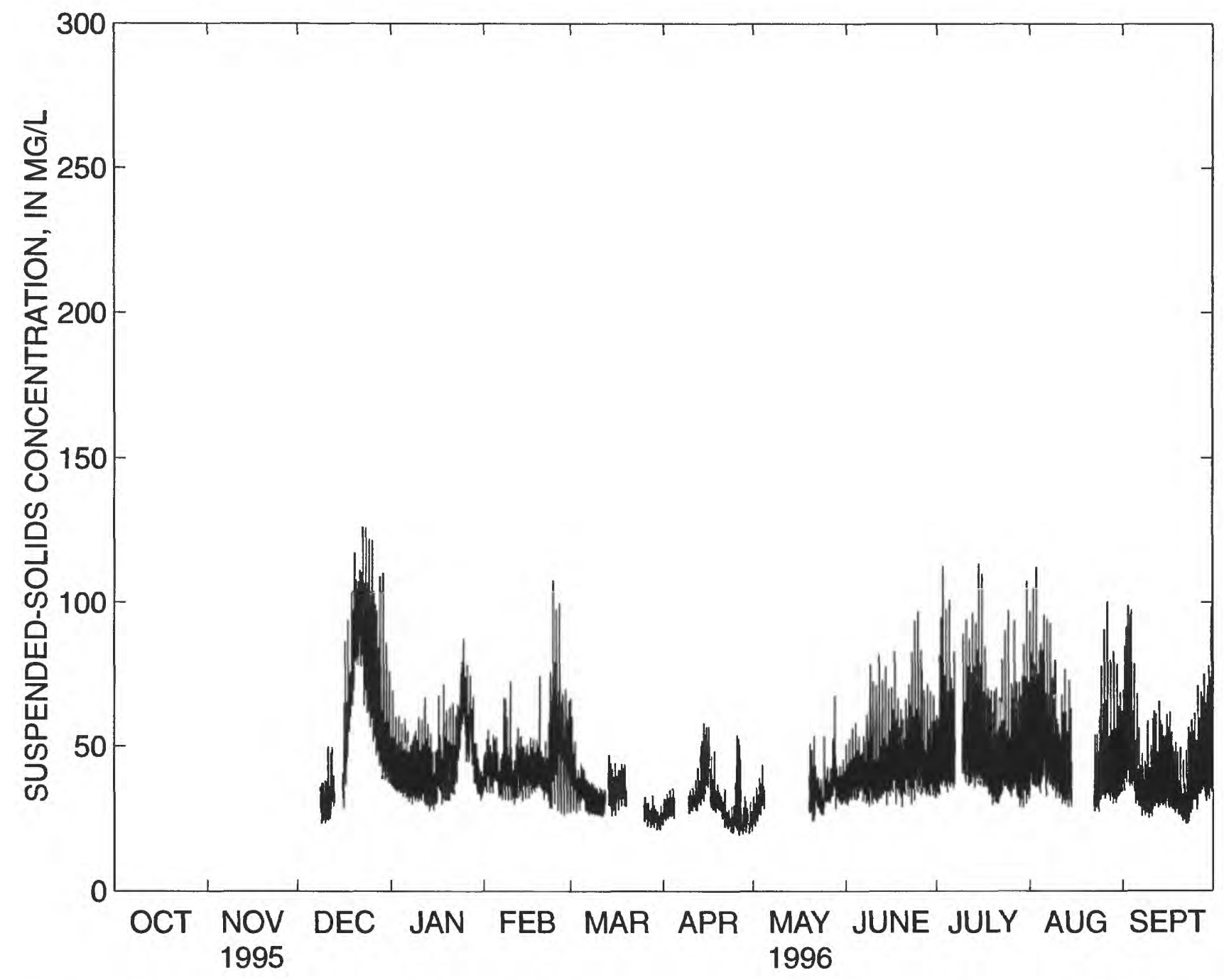

Figure 7. Time series of near-surface suspended-solids concentration calculated from sensor readings at Mallard Island, Suisun Bay, California, water year 1996. 


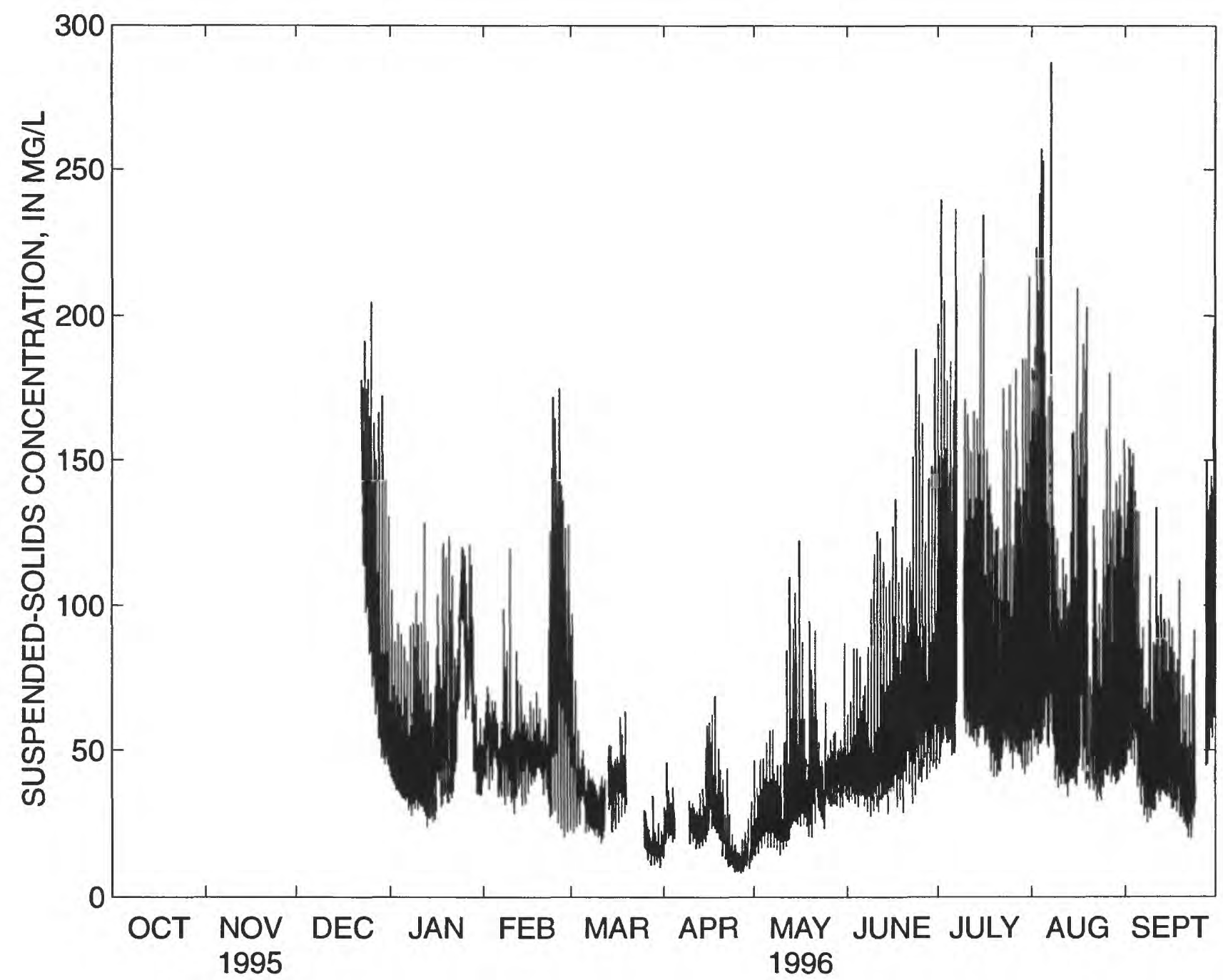

Figure 8. Time series of near-bottom suspended-solids concentration calculated from sensor readings at Mallard Island, Suisun Bay, California, water year 1996. 


\section{Martinez}

Calibration of the near-surface sensor at Martinez had a standard error of $8.9 \mathrm{mg} / \mathrm{L}$ (fig. 9). The calibration was developed using samples collected during the operation of the station (February 8, 1994, through January 18, 1996), excluding samples collected during the flood from January through March 1995 when the sensor output shifted slightly. Suspended-solids concentration data collected during water year 1996 are presented in figure 10. Data collected from January 18 through early February 1996 were lost because of an improperly programmed data logger. In early February 1996, vandals stole the power lines to the instrument shelter. This site was scheduled to be closed in spring 1996 because the Benicia Bridge site was considered to be more representative of suspended-solids concentration in Carquinez Strait. The last suspended-solids concentration data were collected at Martinez on January 18, 1996.

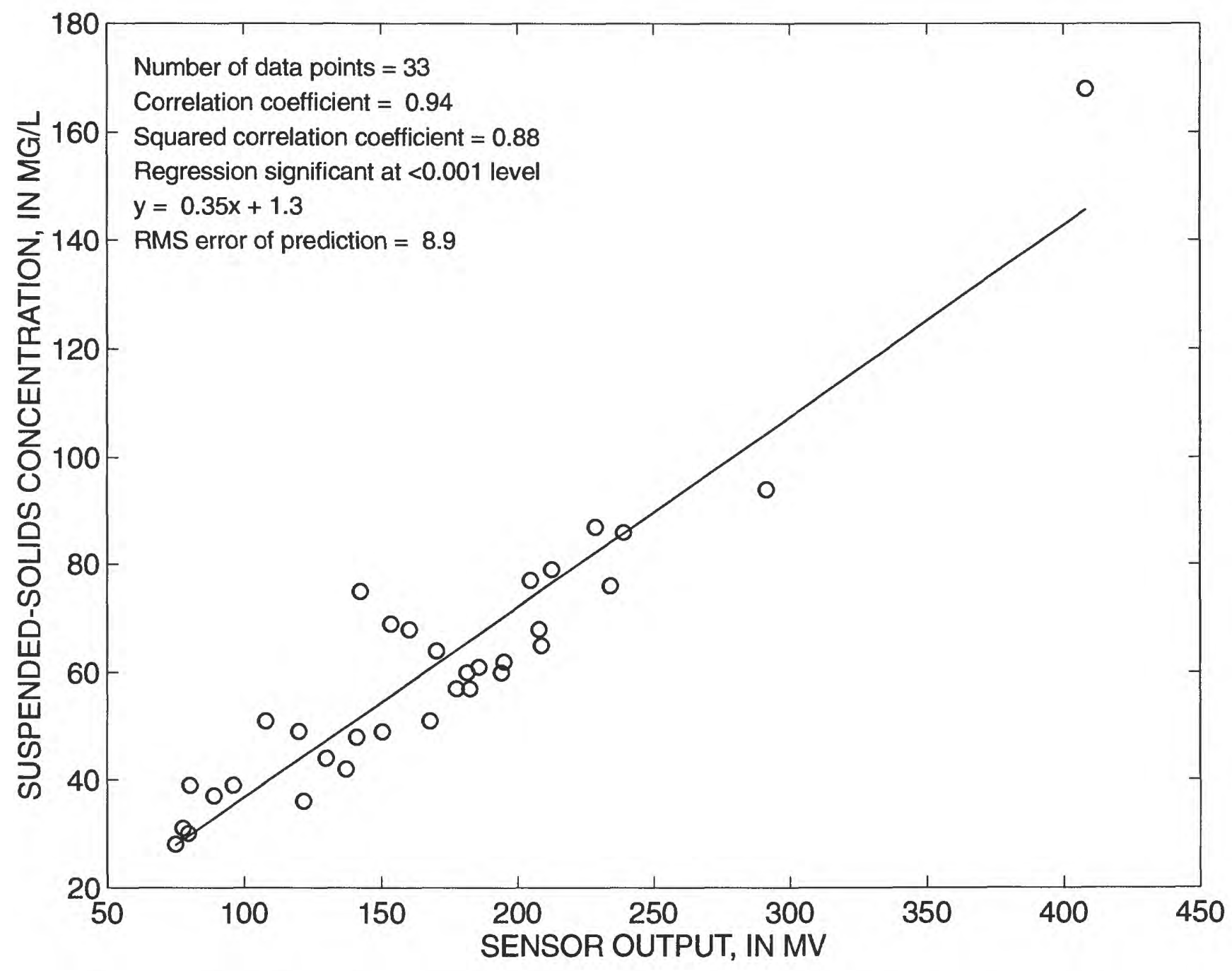

Figure 9. Calibration of near-surface optical backscatterance sensor (with wiper) at Martinez, Suisun Bay, California, water year 1996. 


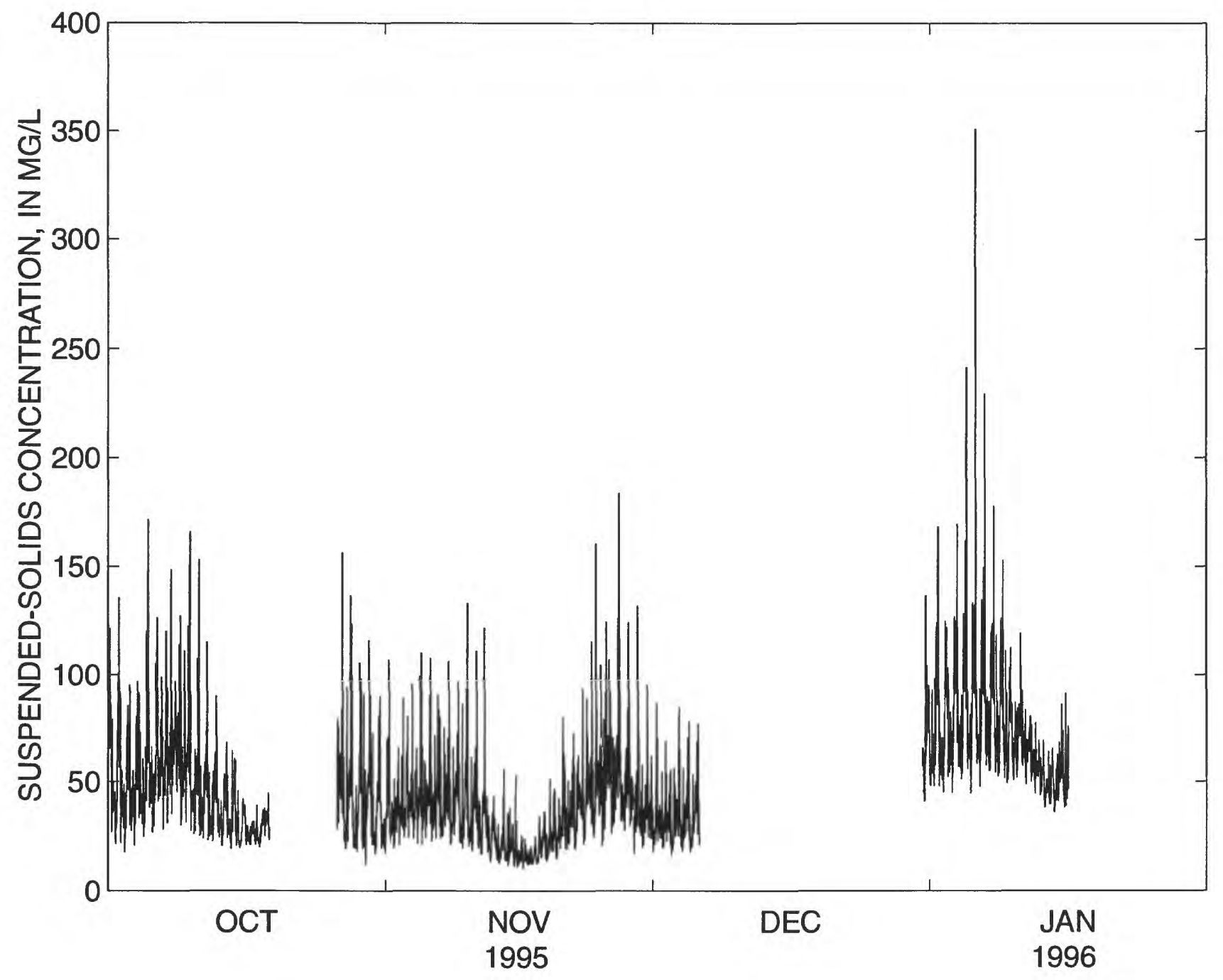

Figure 10. Time series of near-surface suspended-solids concentration calculated from sensor readings at Martinez, Suisun Bay, Califomia, October through January, water year 1996. 


\section{Benicia Bridge}

The near-surface self-cleaning probe deployed on March 15, 1996, failed immediately. A sensor without the self-cleaning function was deployed on May 14, 1996. The calibration of the near-surface sensor had a standard error of $6.6 \mathrm{mg} / \mathrm{L}$ (fig. 11). The near-bottom self-cleaning probe operated from March 15 through April 29, 1996, when it failed. Four water samples were collected during the operation of the sensor and the resulting calibration was poor; therefore, a suspended-solids concentration time series was not determined from this sensor. A sensor without the self-cleaning function was deployed on May 14, 1996. The gain on this sensor was set too high, and some high suspended-solids concentration values were off the scale of the sensor, causing clipping of high suspended-solids concentrations from the time series. The calibration of the near-bottom sensor had a standard error of $44 \mathrm{mg} / \mathrm{L}$ (fig. 12). Because of the short period of data collection for water year 1996, both sensor calibrations included water samples collected through January 9, 1997. Suspended-solids concentration data collected during water year 1996 are presented in figures 13 and 14 . The suspension cable broke sometime in August 1996 resulting in invalid data until September 6, 1996, when the cable was replaced and the sensors redeployed.

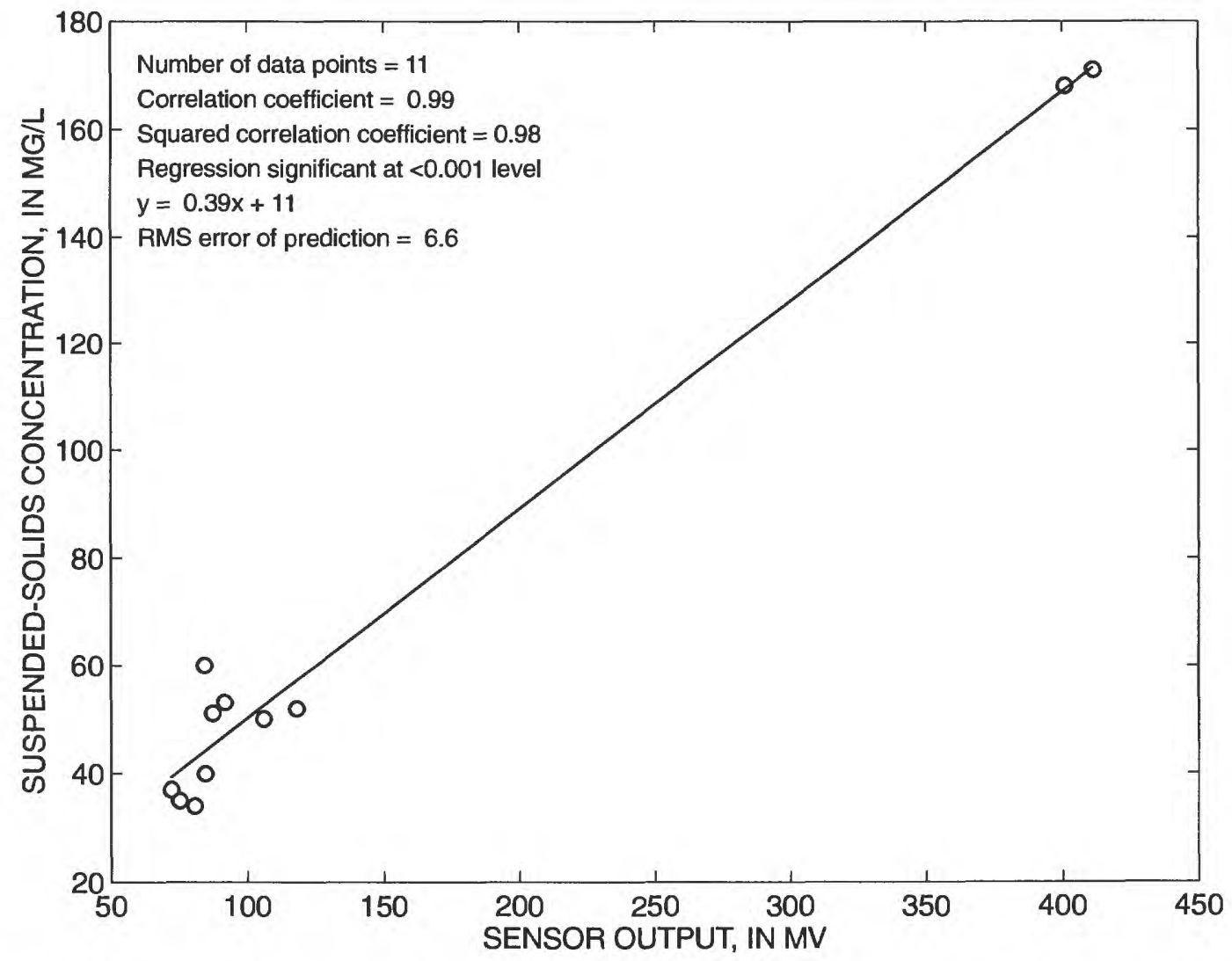

Figure 11. Calibration of near-surface optical backscatterance sensor at Benicia Bridge, Suisun Bay, California, water year 1996. 


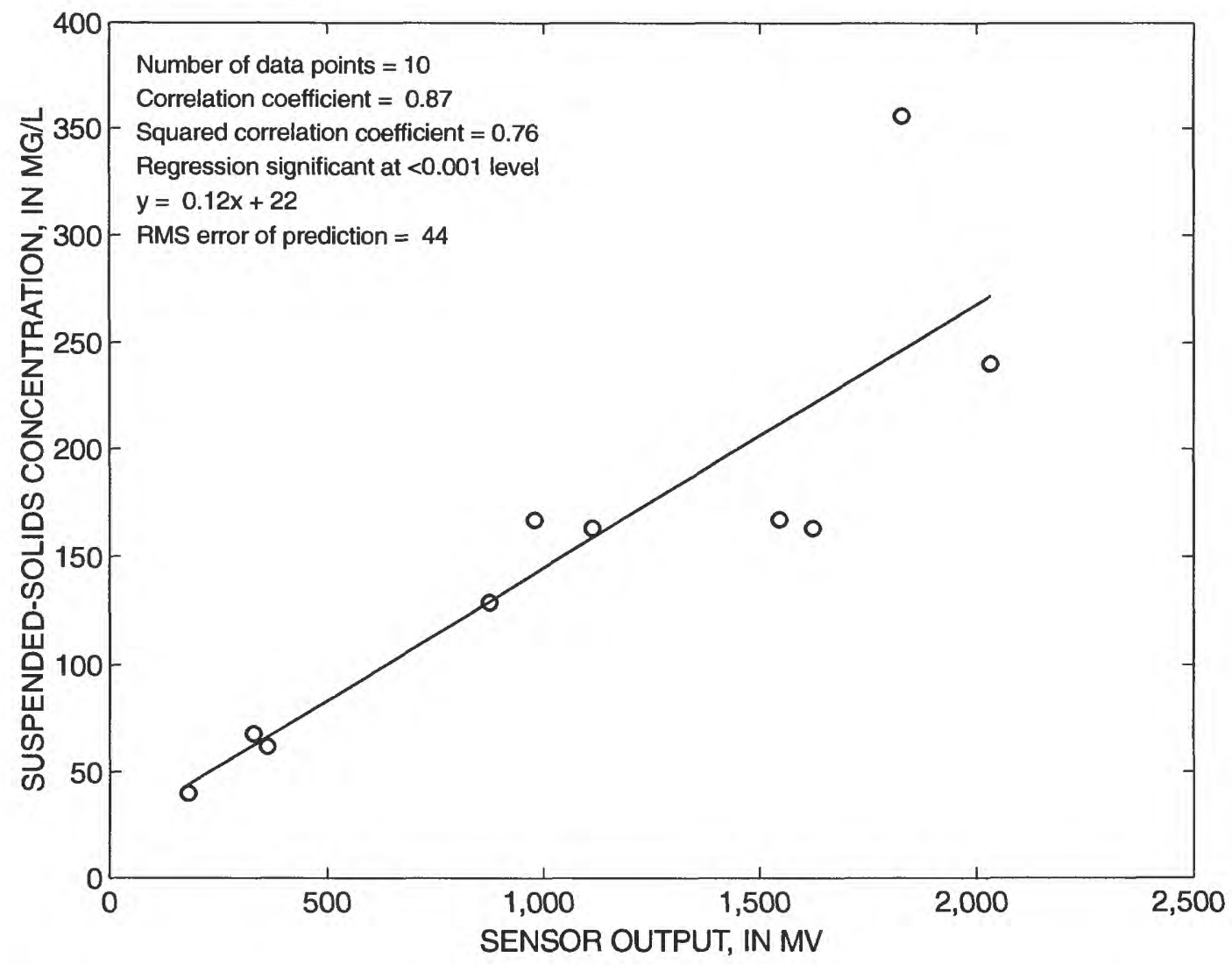

Figure 12. Calibration of near-bottom optical backscatterance sensor at Benecia Bridge, Suisun Bay, California, water year 1996. 


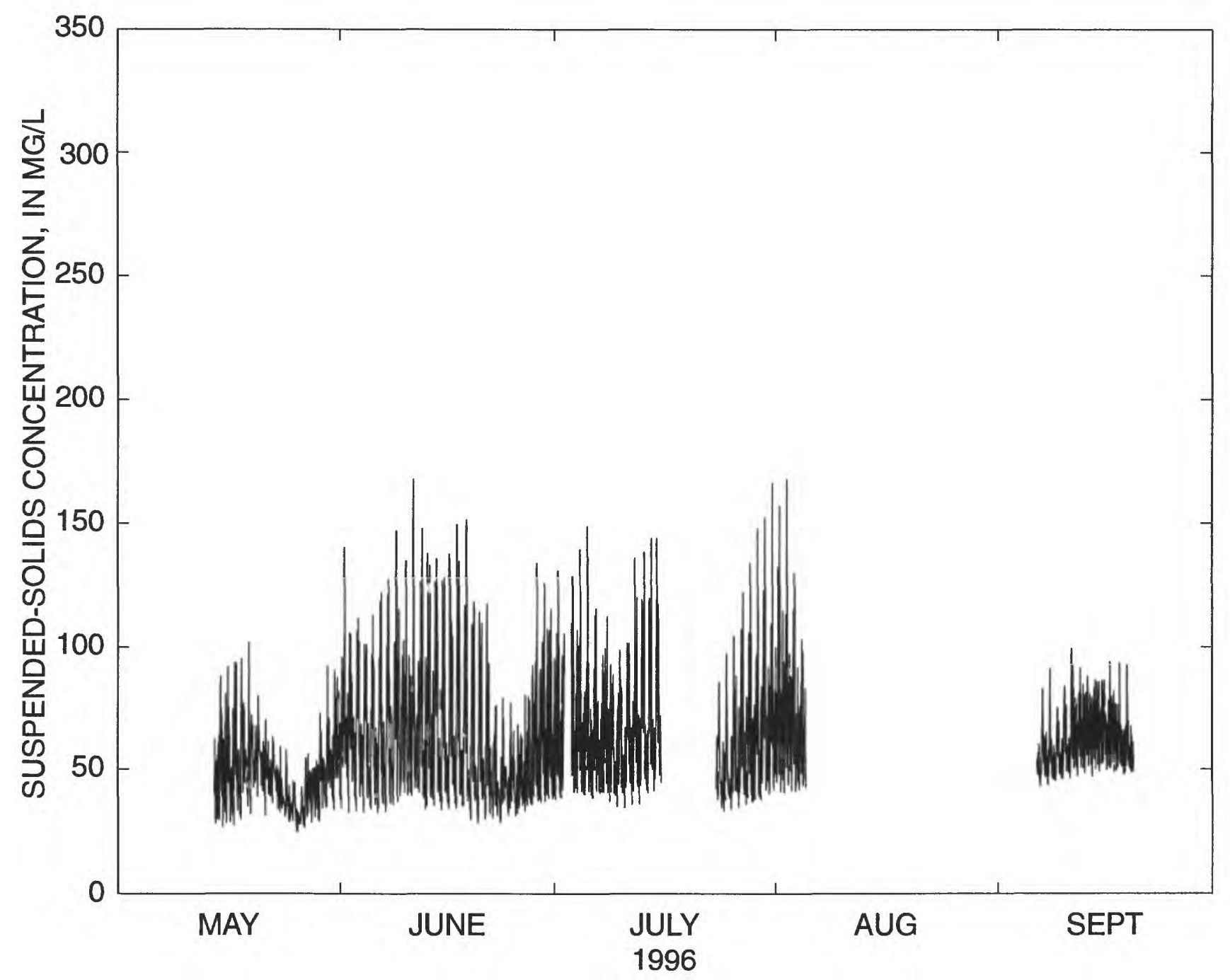

Figure 13. Time series of near-surface suspended-solids concentration calculated from sensor readings at Benicia Bridge, Suisun Bay, California, May through September, water year 1996. 


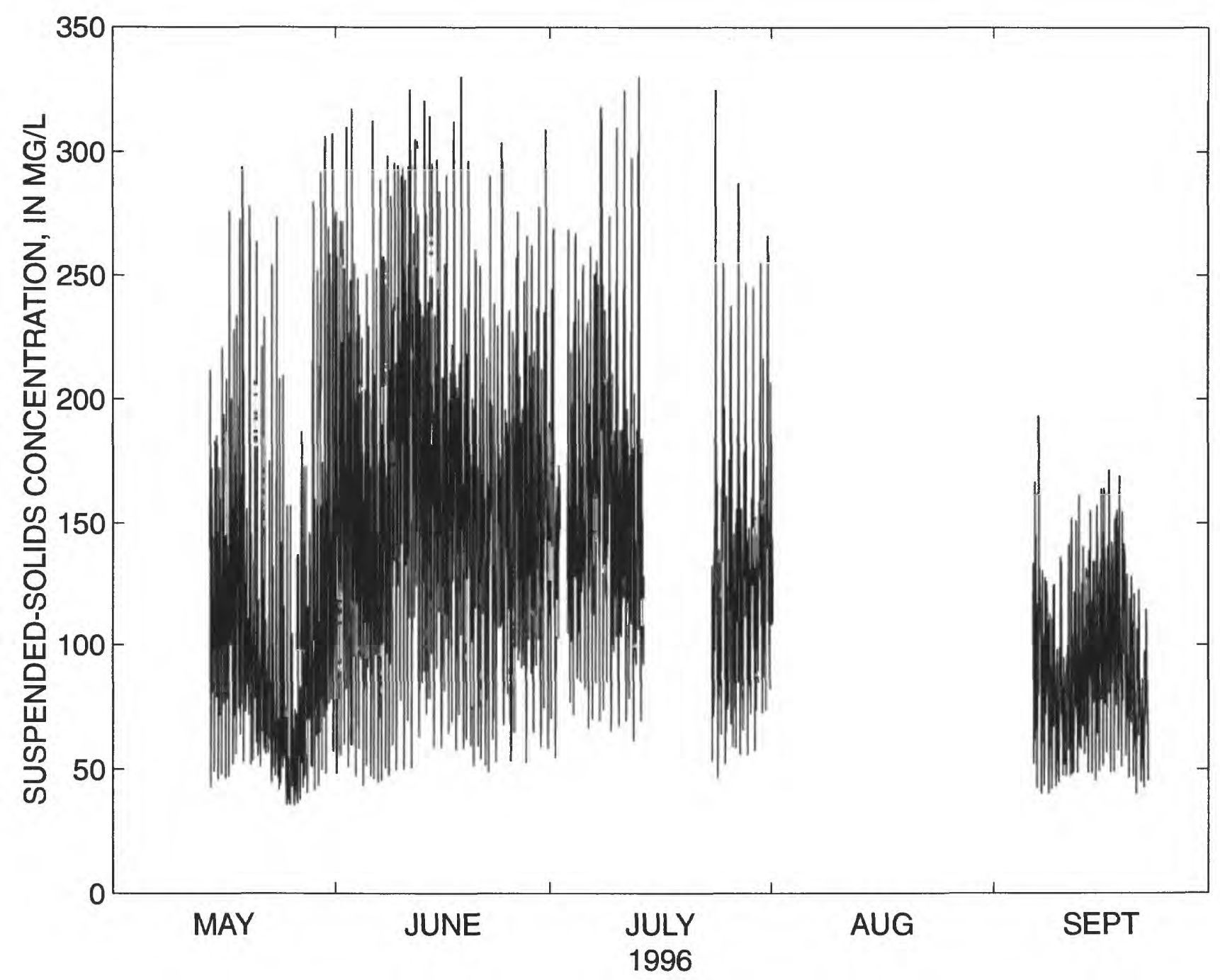

Figure 14. Time series of near-bottom suspended-solids concentration calculated from sensor readings at Benicia Bridge, Suisun Bay, California, May through September, water year 1996. 


\section{Central San Francisco Bay}

\section{Point San Pablo}

Calibration of the mid-depth sensor shifted after cleaning on July 10, 1995. The calibration used in water year 1996 was developed using water samples collected from August 15,1995 , through water year 1996 and had a standard error of $13 \mathrm{mg} / \mathrm{L}$ (fig. 15). The calibration of the near-bottom sensor shifted after cleaning on August 15, 1995. The calibration used during water year 1996 was developed using water samples collected from August 15, 1995, through water year 1996 and had a standard error of $20 \mathrm{mg} / \mathrm{L}$ (fig. 16). Suspended-solids concentration data collected during water year 1996 are presented in figures 17 and 18 .

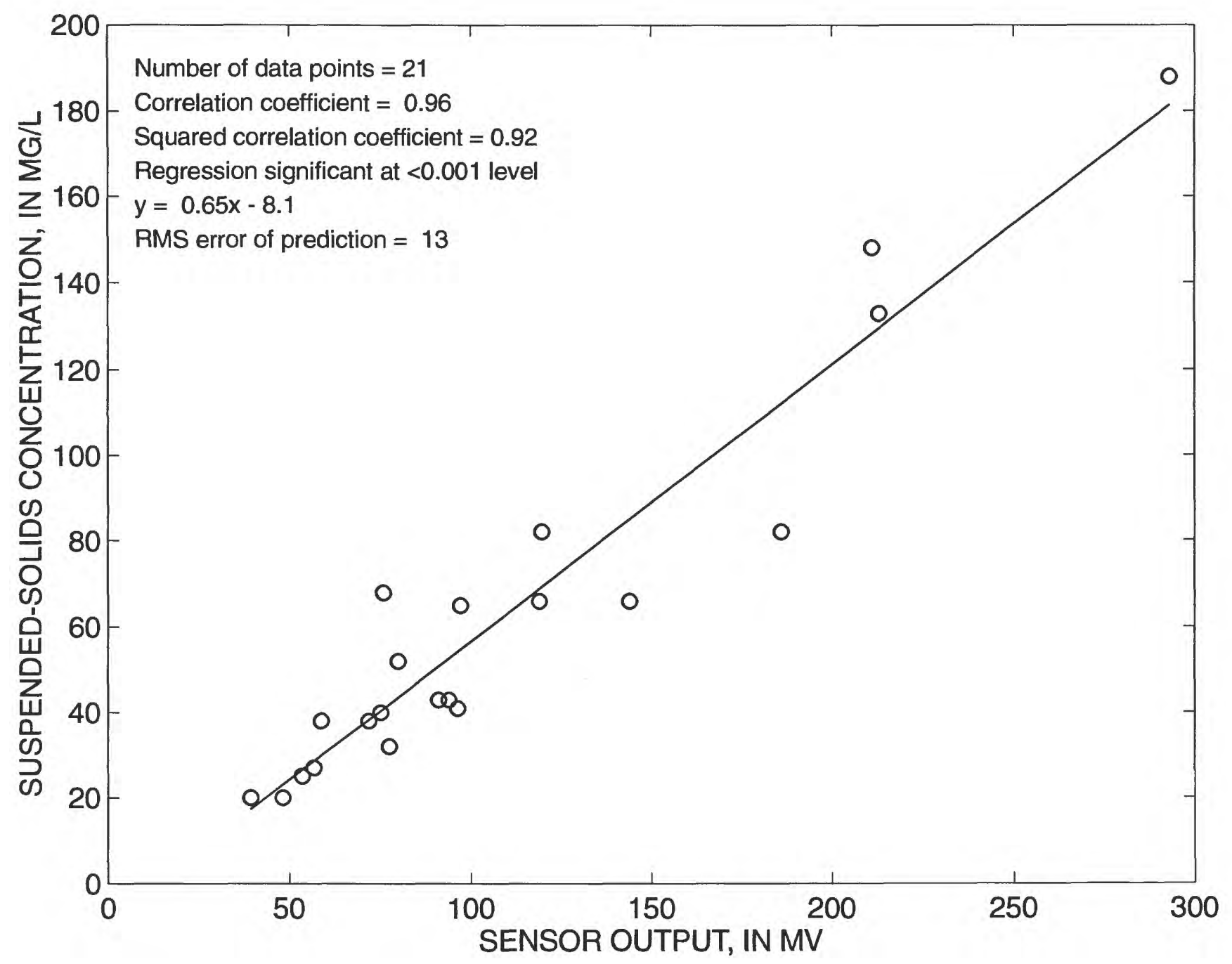

Figure 15. Calibration of mid-depth optical backscatterance sensor at Point San Pablo, Central San Francisco Bay, California, water year 1996. 


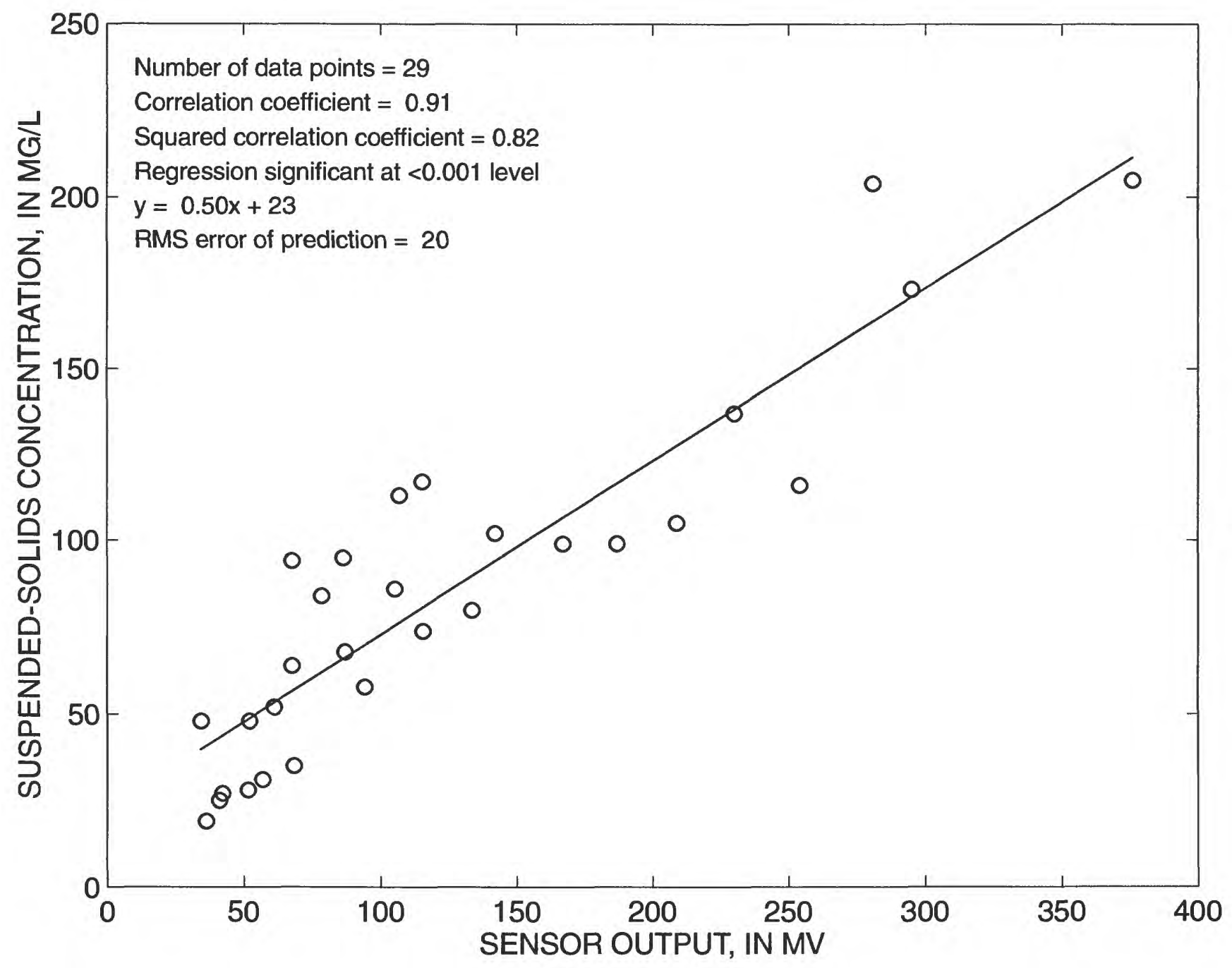

Figure 16. Calibration of near-bottom optical backscatterance sensor at Point San Pablo, Central San Francisco Bay, California, water year 1996. 


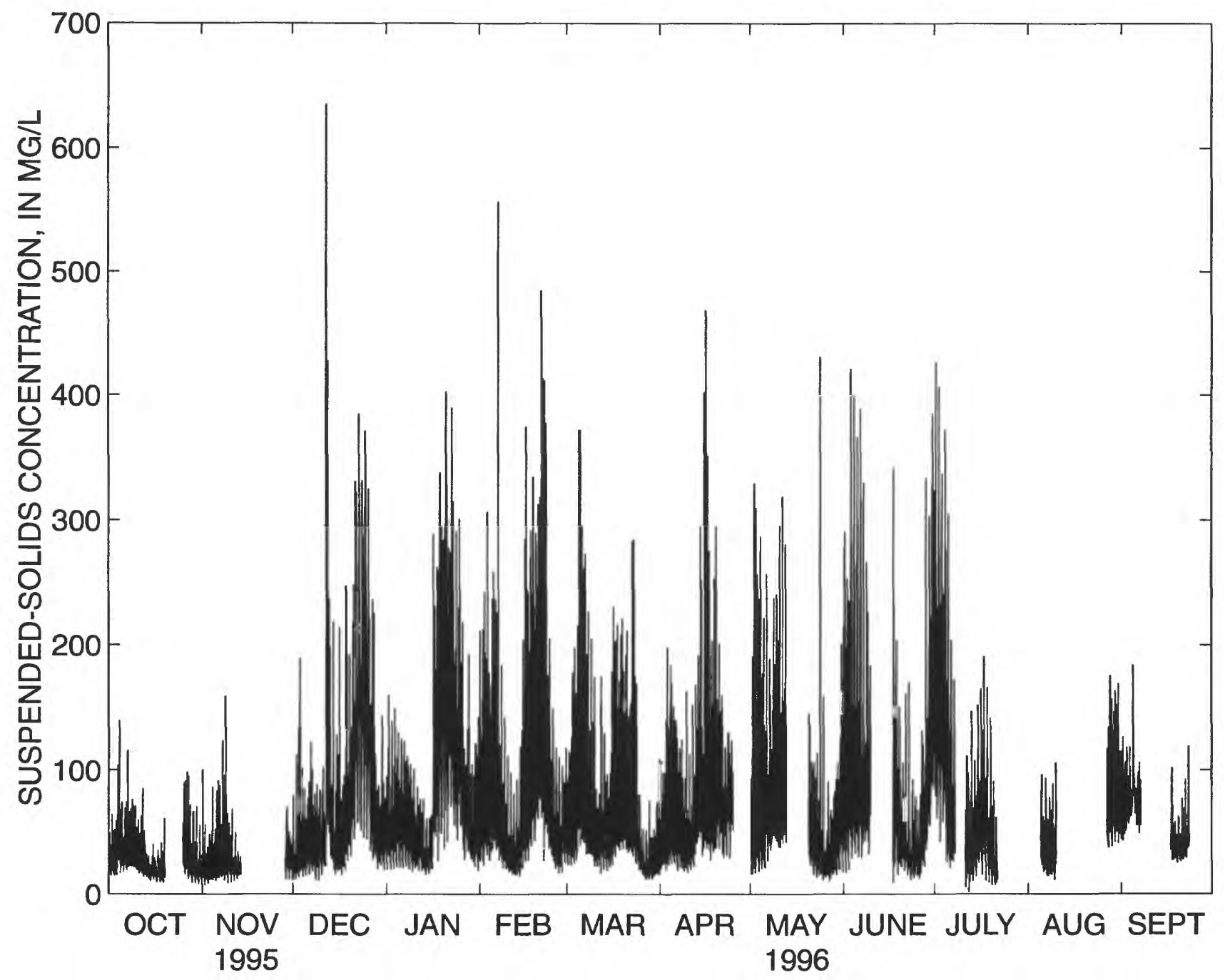

Figure 17. Time series of mid-depth suspended-solids concentration calculated from sensor readings at Point San Pablo, Central San Francisco Bay, California, water year 1996. 


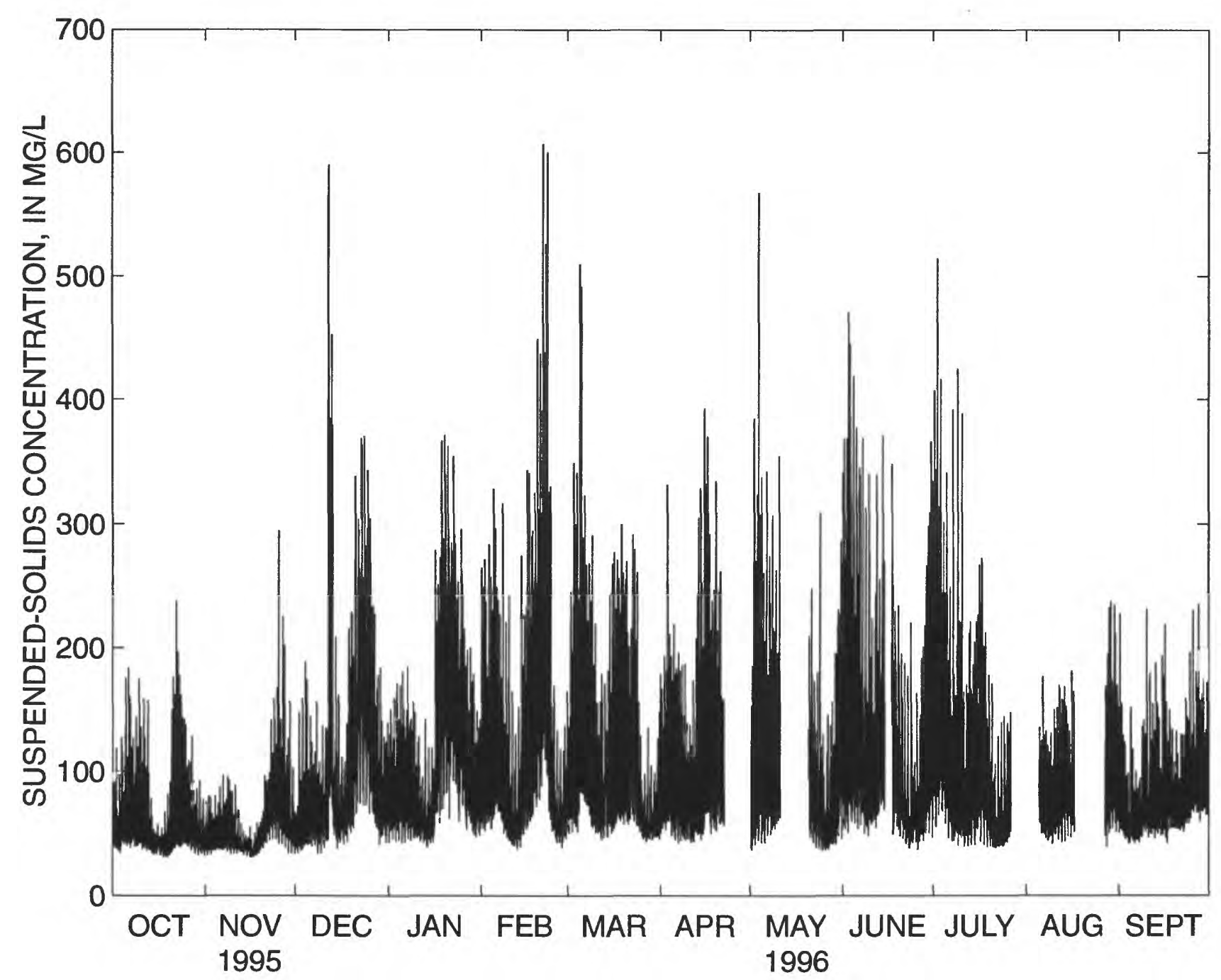

Figure 18. Time series of near-bottom suspended-solids concentration calculated from sensor readings at Point San Pablo, Central San Francisco Bay, California, water year 1996. 


\section{Pier 24}

Calibration of the mid-depth sensor was developed from water samples collected from September 1994 through water year 1996 and had a standard error of $12 \mathrm{mg} / \mathrm{L}$ (fig. 19). Shifts to the mid-depth record, calculated from water-sample data not shown on figure 19, were applied during the following periods: $-34 \mathrm{mV}$, October 1-5, 1995; -41 mV, November 21, 1995, through January 12, 1996; -47 mV, June 5 through July 2, 1996; -13 mV, August 6-29, 1996; -36 mV, August 29 through September 18, 1996; and -61 mV, September 18-30, 1996. Calibration of the near-bottom sensor was developed from water samples collected from June 22,1995 , through water year 1996 and had a standard error of $18 \mathrm{mg} / \mathrm{L}$ (fig. 20). A shift in sensor output appears to have occurred in June 1996, but water sample data did not indicate that any applied shifts were justifiable. Suspended-solids concentration data collected during water year 1996 are presented in figures 21 and 22.

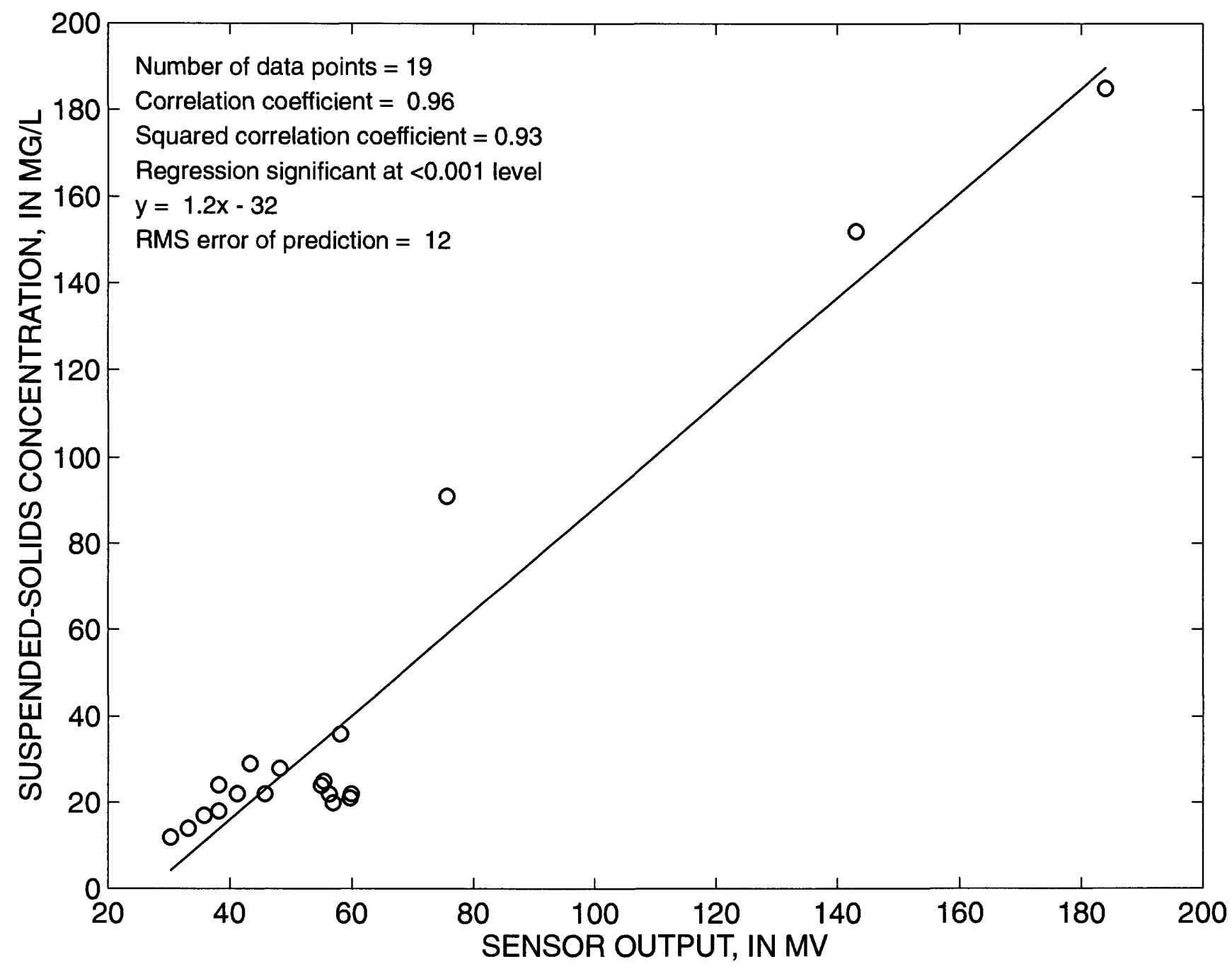

Figure 19. Calibration of mid-depth optical backscatterance sensor at Pier 24, Central San Francisco Bay, California, water year 1996. 


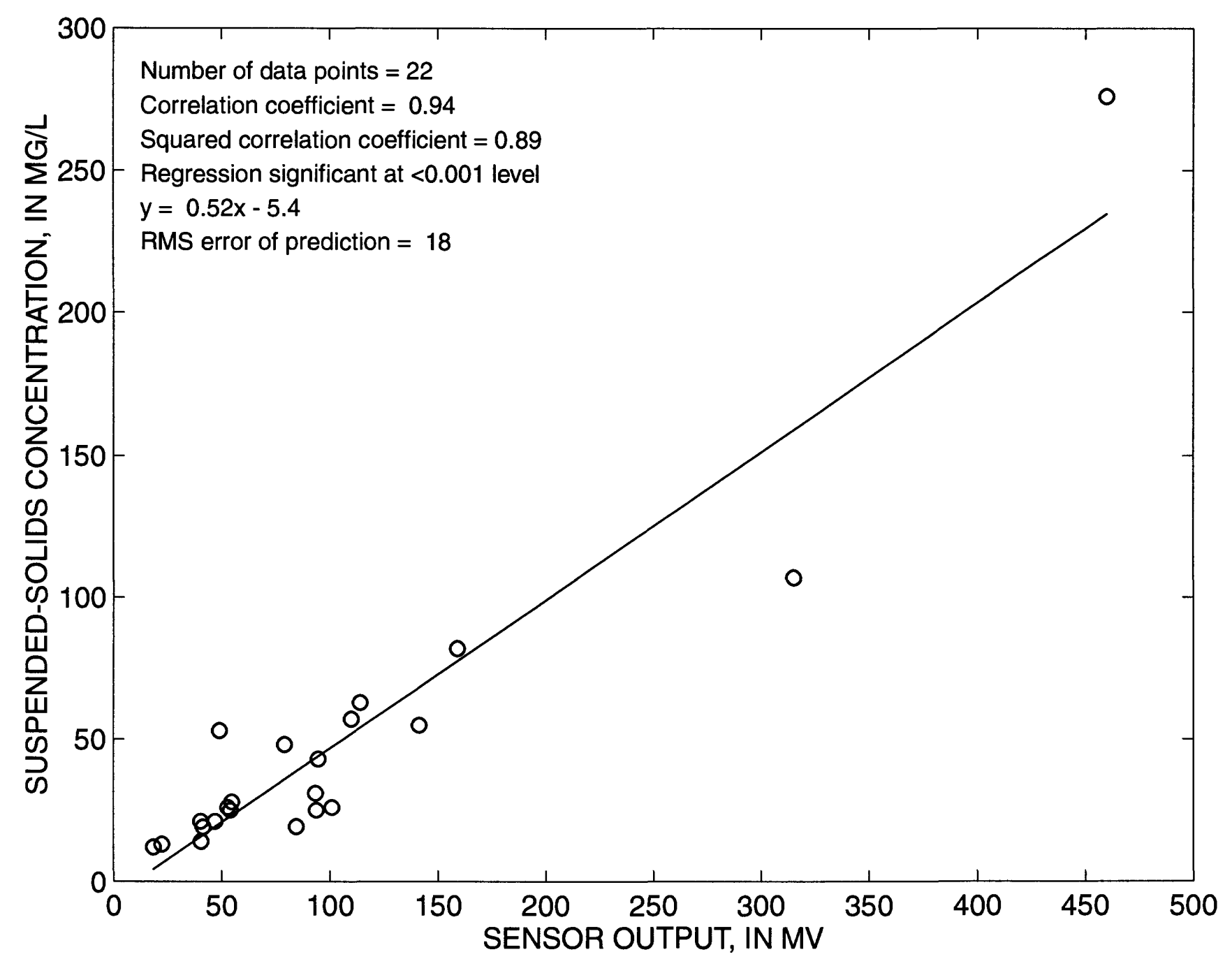

Figure 20. Calibration of near-bottom optical backscatterance sensor at Pier 24, Central San Francisco Bay, California, water year 1996. 


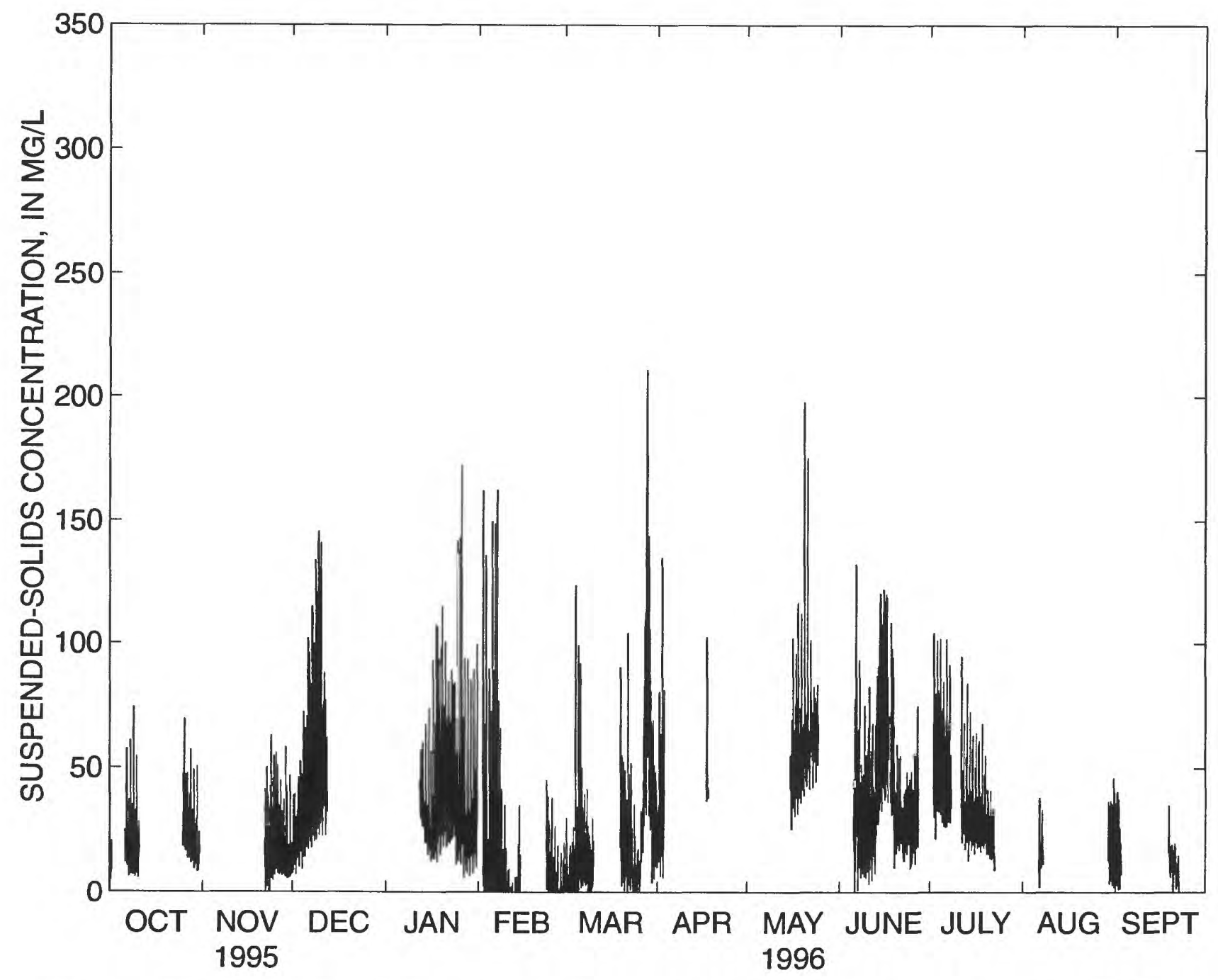

Figure 21. Time series of mid-depth suspended-solids concentration calculated from sensor readings at Pier 24, Central San Francisco Bay, California, water year 1996. 


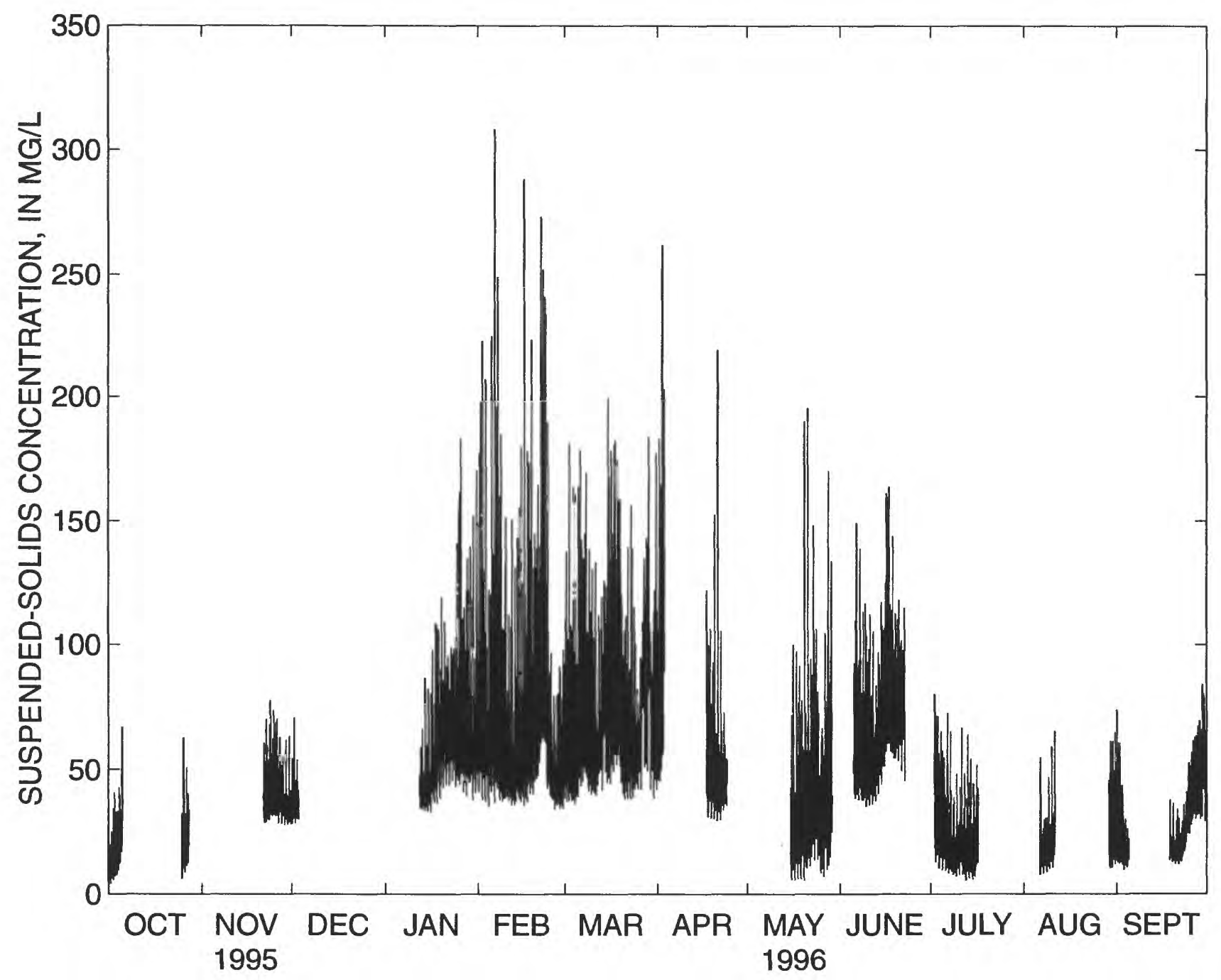

Figure 22. Time series of near-bottom suspended-solids concentration calculated from sensor readings at Pier 24, Central San Francisco Bay, California, water year 1996. 


\section{Golden Gate Bridge}

Suspended-solids concentration data proved difficult to collect at the South Tower of the Golden Gate Bridge. An optical sensor deployed on October 17, 1995, failed on November 21, 1995 (possibly from severe vibrations caused by the extreme tides), and was not replaced until January 10, 1996. Water samples collected were insufficient to develop a calibration, so no suspended-solids concentrations were derived. The optical sensor in operation from January 1024, 1996, was calibrated using 6 samples collected at the Golden Gate Bridge (output less than $200 \mathrm{mV}$ ) and 21 samples collected in Suisun Bay during water year 1995 (output greater than $200 \mathrm{mV}$ ) and had a standard error of $8.7 \mathrm{mg} / \mathrm{L}$ (fig. 23). On February 1, 1996, the cable connection on the sensor was found to be loose, which caused the sensor to flood, resulting in a loss of data from January 24 through February 1, 1996. Calibration of the replacement sensor, in operation from February 1 through April 2, 1996, was developed using 3 samples collected at the Golden Gate Bridge (output less than $150 \mathrm{mV}$ ) and 16 samples collected in Suisun Bay during water year 1995 (output greater than $150 \mathrm{mV}$ ) and had a standard error of $8.2 \mathrm{mg} / \mathrm{L}$ (fig. 24). A shift to the record from February 1-10, 1996, was not defined with water samples, and suspended-solids concentrations were not derived for this period. A $-320 \mathrm{mV}$ shift to the record, calculated from water-sample data not shown on figure 24, was applied from February 10-16, 1996. On March 14, 1996, the carriage was found to be broken, and a replacement could not be installed because of the strong current. The sensor was redeployed March 22, 1996, at which time the sensor was recording inordinately high values (sensor probably damaged when the carriage broke). The data from March 22 through April 2, 1996, were invalid. The replacement sensor deployed on April 2, 1996, was calibrated using nine water samples and had a standard error of $6.9 \mathrm{mg} / \mathrm{L}$ (fig. 25). A shift occurred after sensor cleaning on June 6, 1996, and the calibration developed from 10 samples had a standard error of $4.2 \mathrm{mg} / \mathrm{L}$ (fig. 26) and was used through the end of the water year. Suspended-solids concentration data collected during water year 1996 are presented in figure 27. 


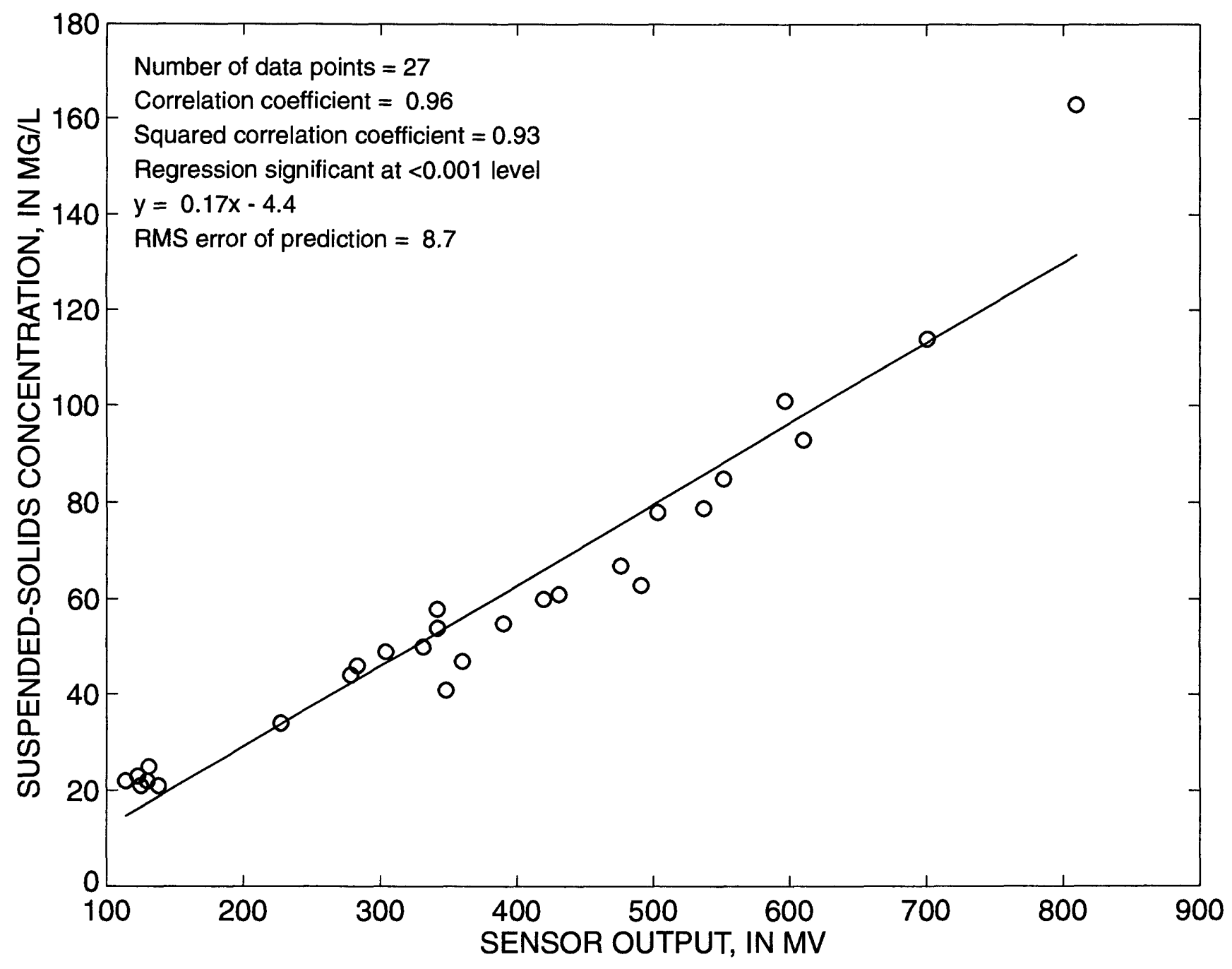

Figure 23. Calibration of mid-depth optical backscatterance sensor at Golden Gate Bridge, Central San Francisco Bay, California, January 10-24, water year 1996. 


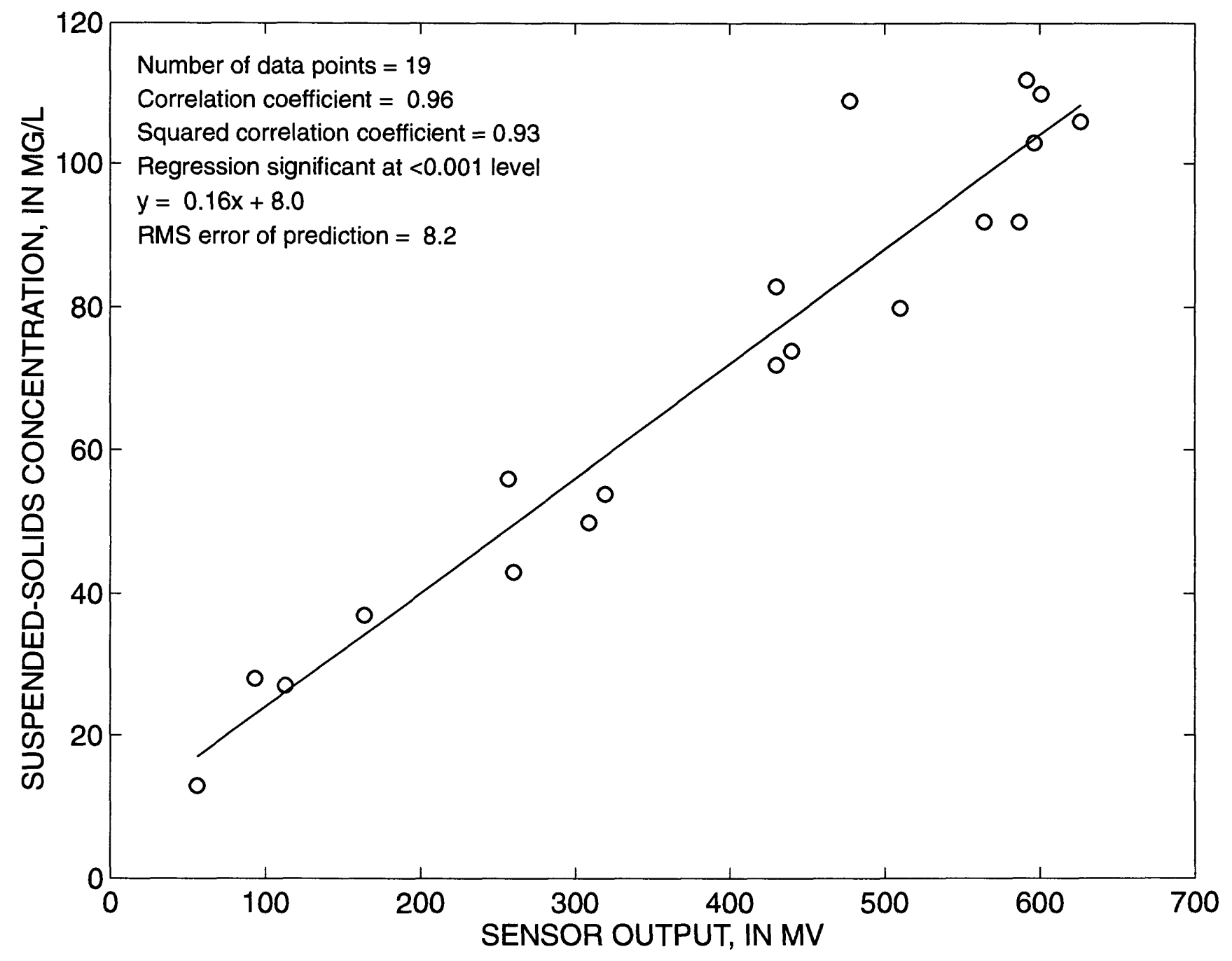

Figure 24. Calibration of mid-depth optical backscatterance sensor at Golden Gate Bridge, Central San Francisco Bay, California, February 16 through March 14, water year 1996. 


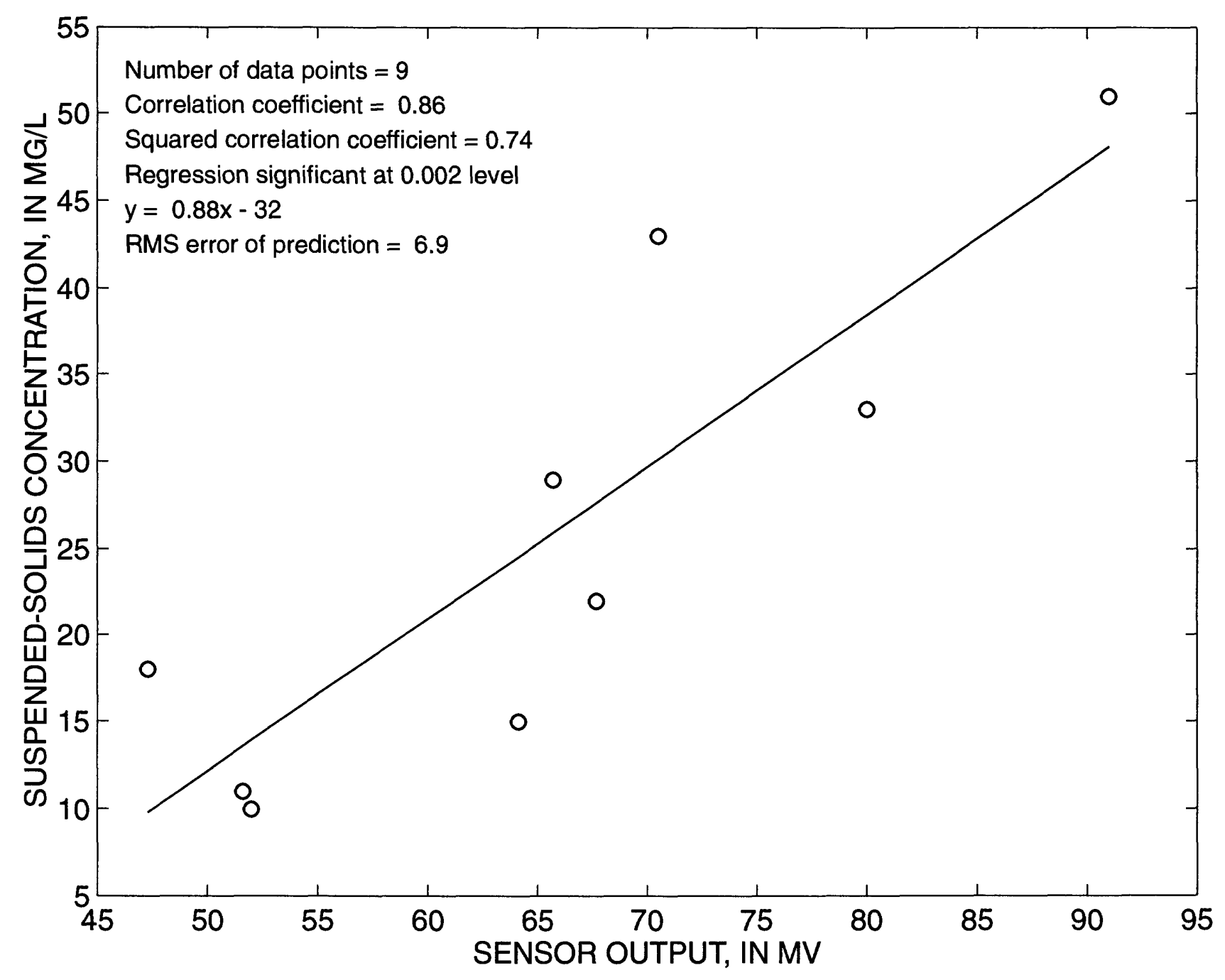

Figure 25. Calibration of mid-depth optical backscatterance sensor at Golden Gate Bridge, Central San Francisco Bay, California, April 2 through June 6, water year 1996. 


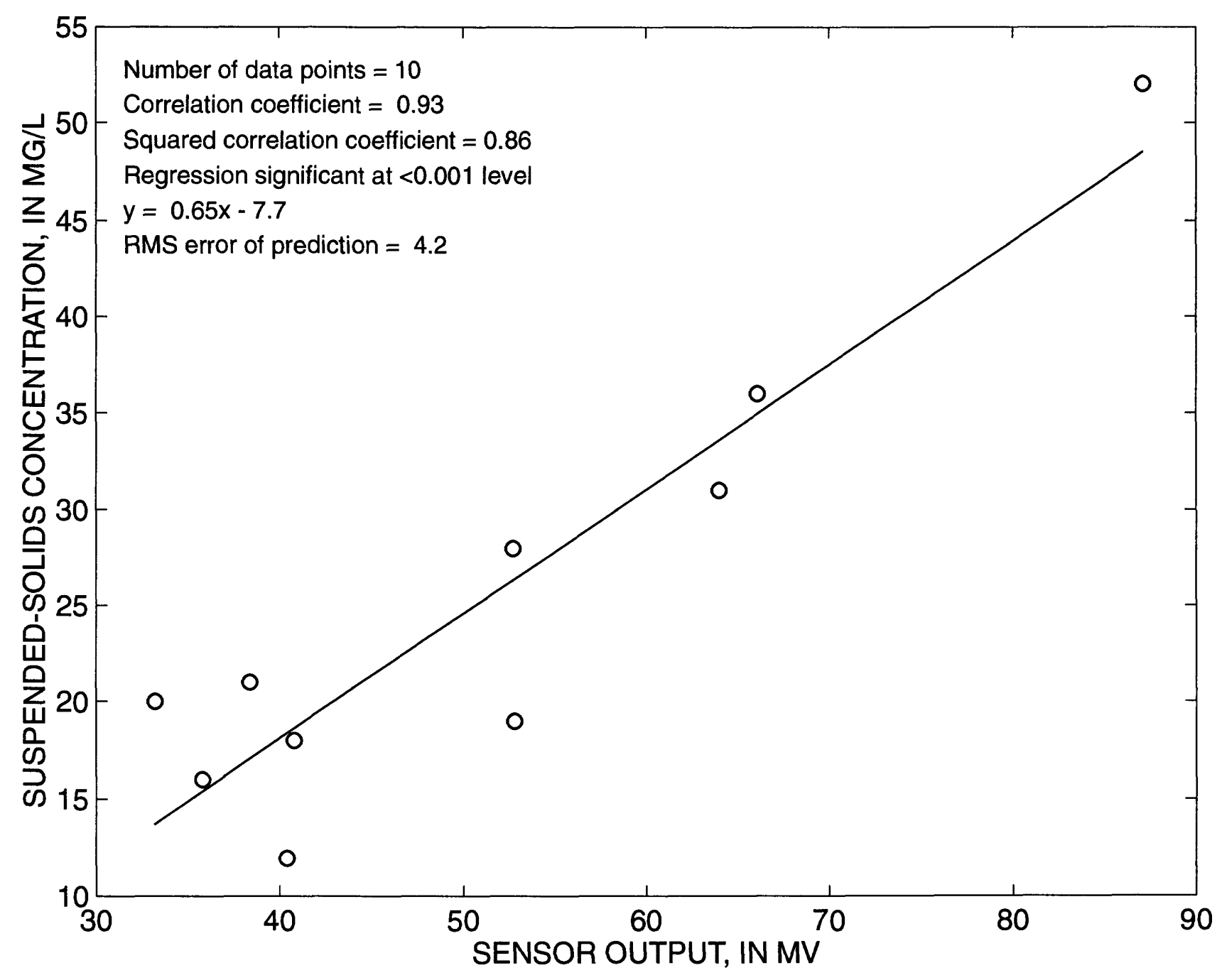

Figure 26. Calibration of mid-depth optical backscatterance sensor at Golden Gate Bridge, Central San Francisco Bay, California, June 6 through September 30, water year 1996. 


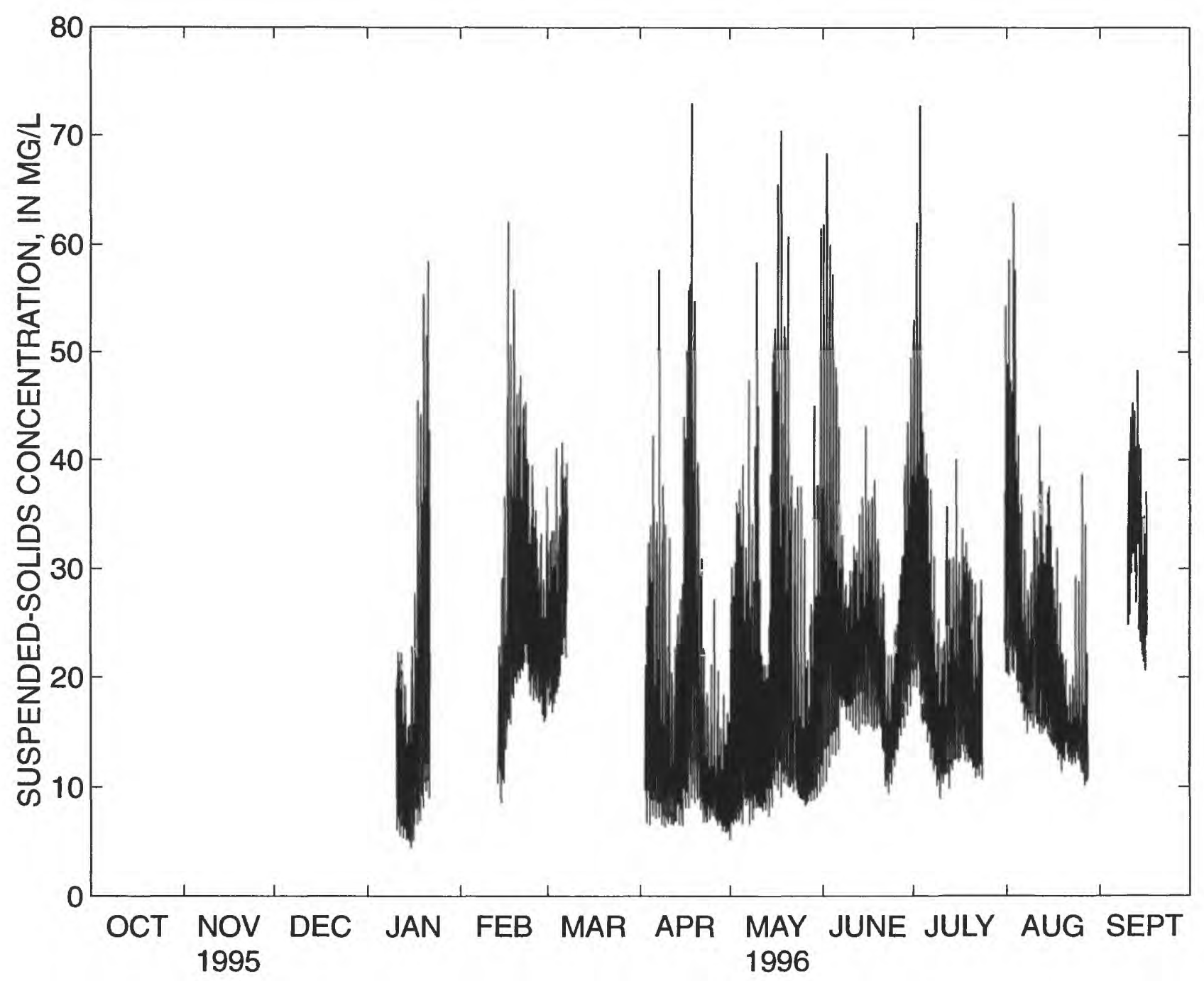

Figure 27. Time series of mid-depth suspended-solids concentration calculated from sensor readings at Golden Gate Bridge, Central San Francisco Bay, water year 1996. 


\section{South San Francisco Bay}

\section{Channel Marker 17}

The calibration of the mid-depth sensor was based on 23 samples collected during water years 1995 and 1996 and had a standard error of $29 \mathrm{mg} / \mathrm{L}$ (fig. 28). The sensor periodically malfunctioned from November 1995 through March 6, 1996, during which time the data had many missing values and accuracy was considered poor. On March 6, 1996, the sensor became inoperable and resulted in a loss of data through May 9, 1996, when the sensor was replaced. The calibration of the replacement sensor had a standard error of $23 \mathrm{mg} / \mathrm{L}$ (fig. 29). The gain on this sensor was mistakenly set high so that high suspended-solids concentrations often saturated the sensor, which could measure a maximum concentration of approximately $520 \mathrm{mg} / \mathrm{L}$. The calibration of the near-bottom sensor was based on 37 samples collected during water years 1995 and 1996 and had a standard error of $37 \mathrm{mg} / \mathrm{L}$ (fig. 30). The near-bottom sensor cable was damaged on November 22, 1995, which resulted in a loss of data through January 11, 1996. Suspended-solids concentration data collected during water year 1996 are presented in figures 31 and 32. 


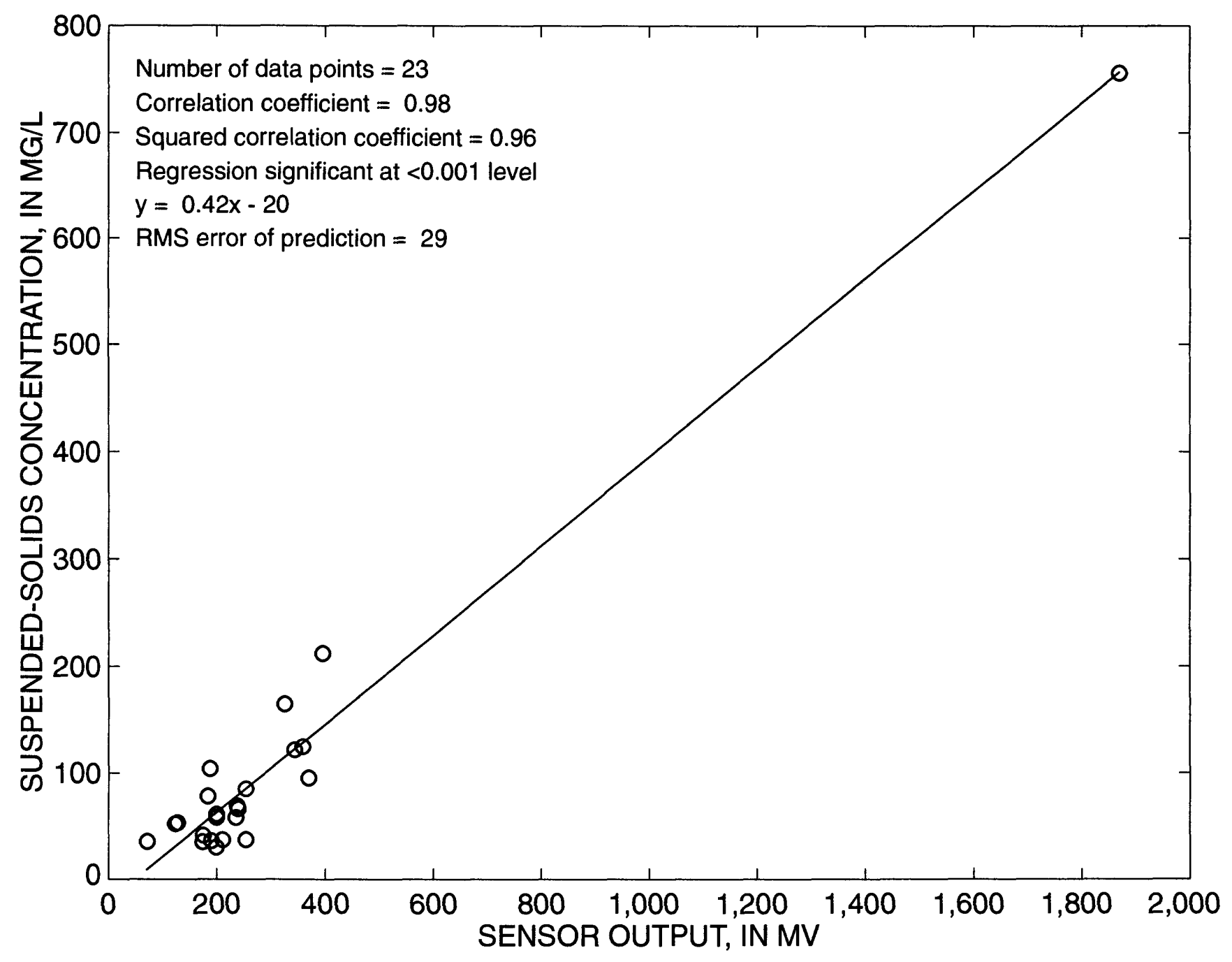

Figure 28. Calibration of mid-depth optical backscatterance sensor at channel marker 17, South San Francisco Bay, California, October 1 through March 6, water year 1996. 


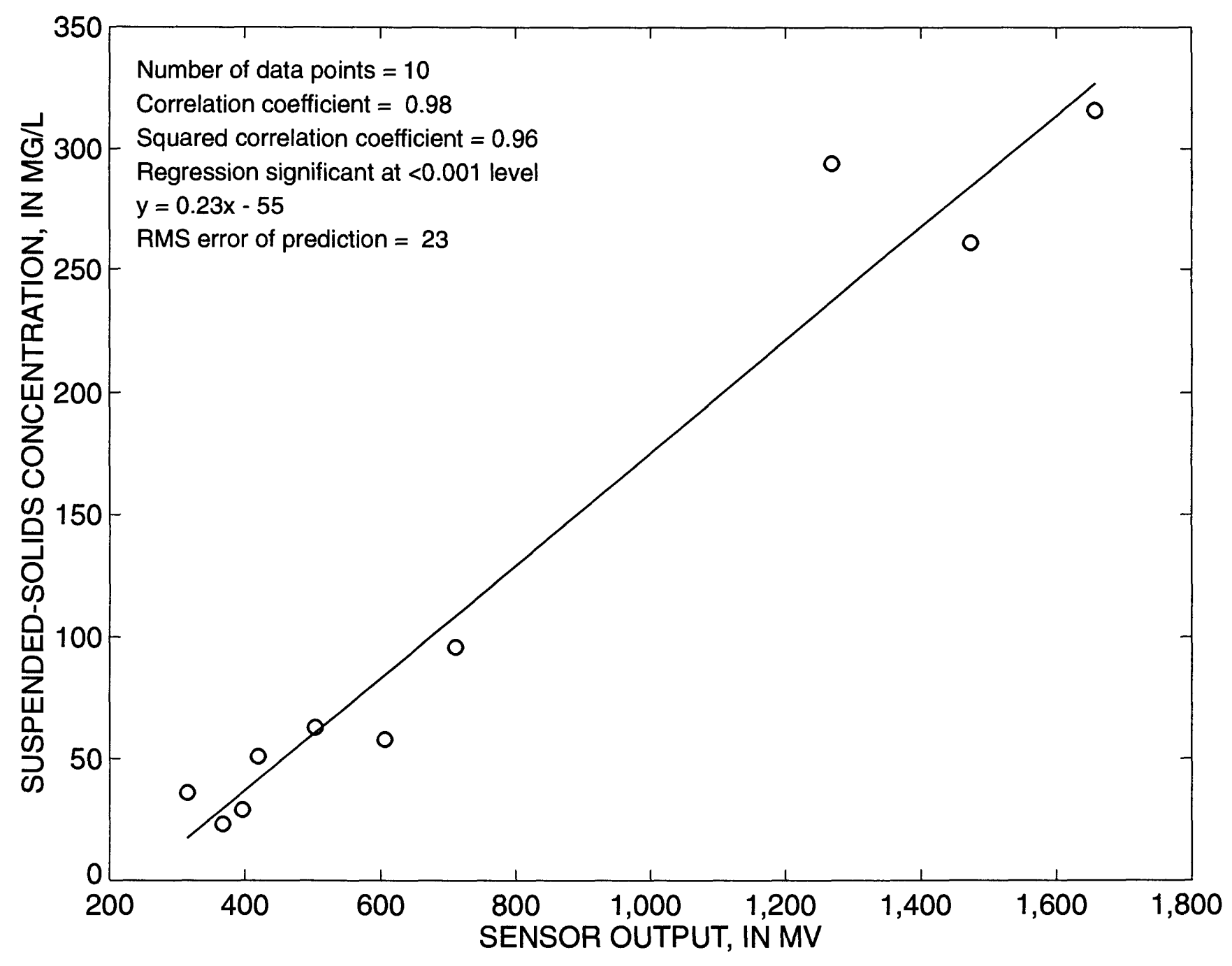

Figure 29. Calibration of mid-depth optical backscatterance sensor at channel marker 17, South San Francisco Bay, California, May 9 through September 30, water year 1996. 


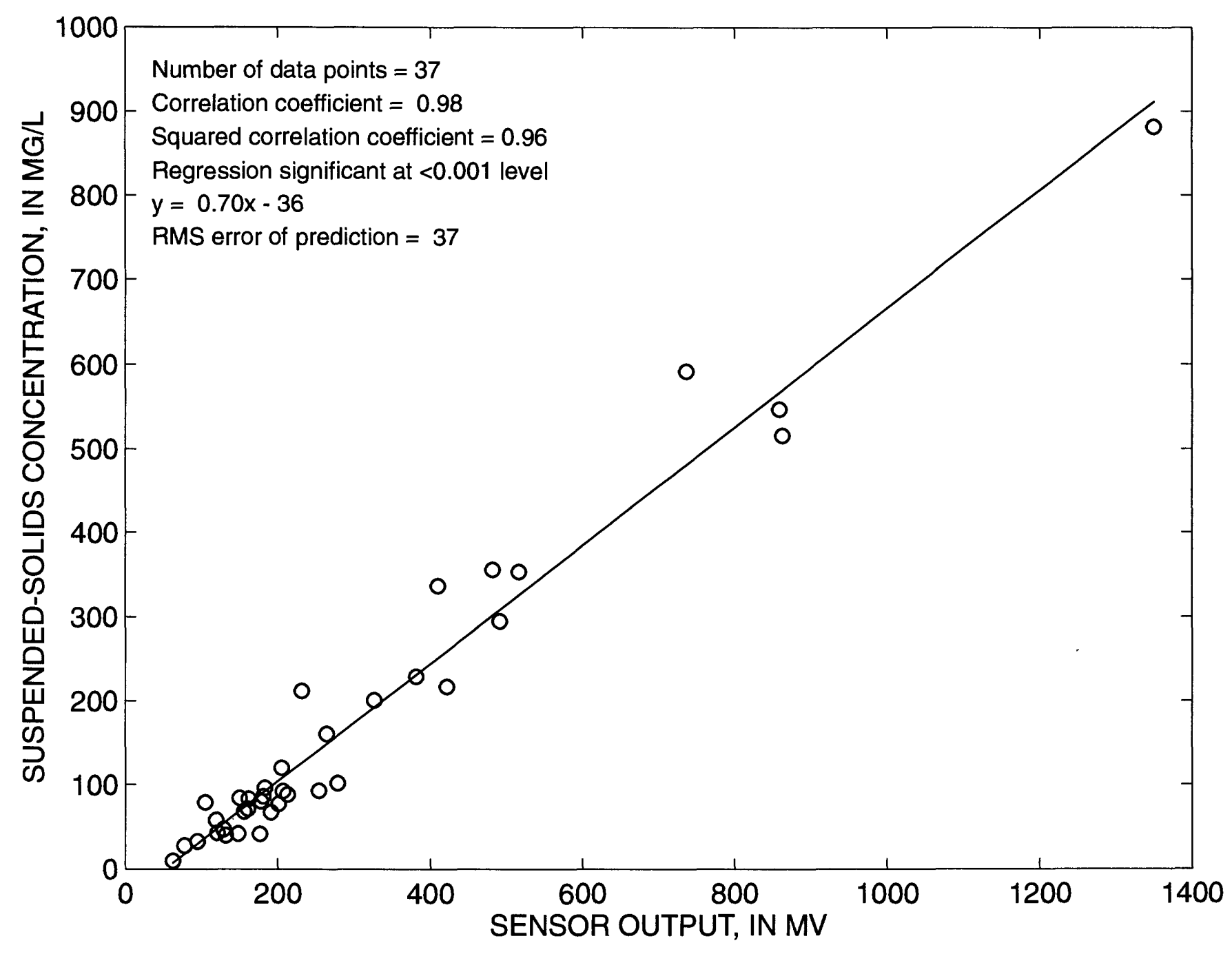

Figure 30. Calibration of near-bottom optical backscatterance sensor at channel marker 17, South San Francisco Bay, California, water year 1996. 


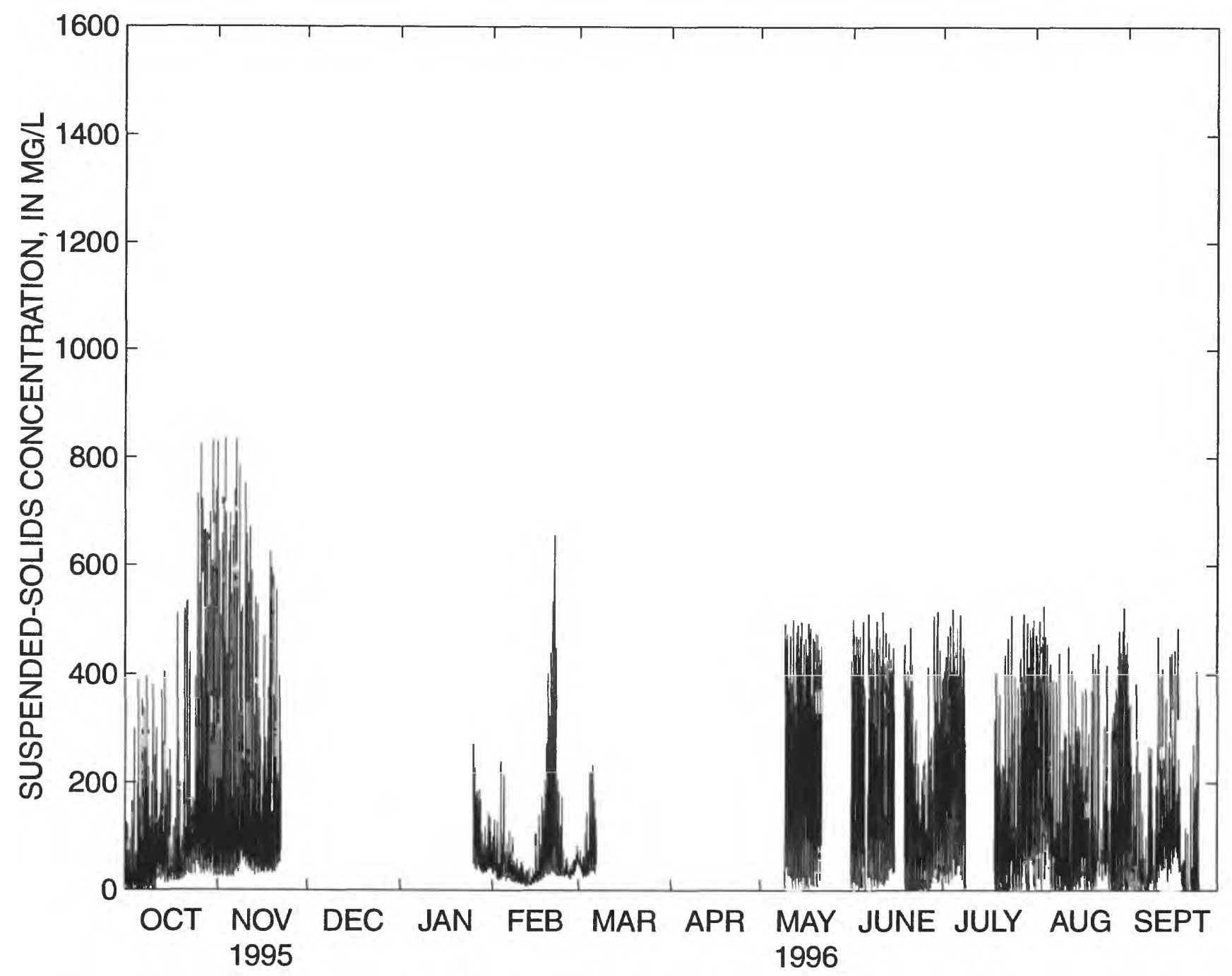

Figure 31. Time series of mid-depth suspended-solids concentration calculated from sensor readings at channel marker 17, South San Francisco Bay, California, water year 1996. 


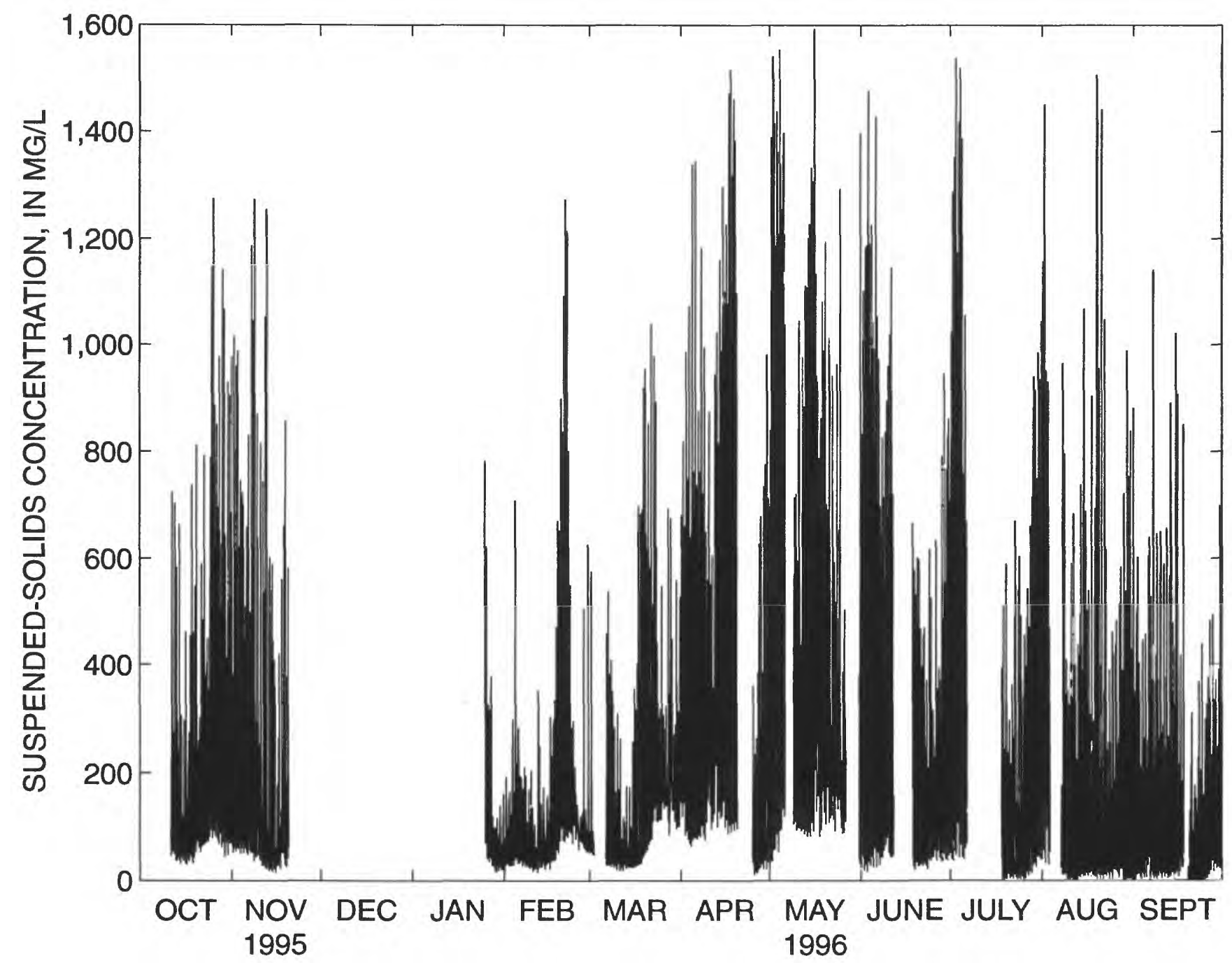

Figure 32. Time series of near-bottom suspended-solids concentration calculated from sensor readings at channel marker 17, South San Francisco Bay, California, water year 1996. 


\section{Dumbarton Bridge}

The mid-depth wiper probe failed in May 1995 and was replaced with an optical sensor without the self-cleaning function on October 12, 1995. The calibration of the mid-depth sensor had a standard error of $28 \mathrm{mg} / \mathrm{L}$ (fig. 33). The mid-depth sensor failed in April 1996 and was replaced with a newer version of the self-cleaning probe on May 8, 1996. The new self-cleaning probe failed within a month; therefore, a calibration curve was not developed for this sensor. An optical sensor without the self-cleaning function was deployed on June 18, 1996, and operated through the remainder of the water year. The calibration of the mid-depth sensor in operation from June 18 through September 30, 1996, had a standard error of $7.4 \mathrm{mg} / \mathrm{L}$ (fig. 34). A shift in the calibration of the mid-depth sensor may have occurred after cleaning of heavy fouling on August 8,1996 , as indicated by the shifts applied to the following periods: $-71 \mathrm{mV}$, August 8-28, 1996; -33 mV, August 28 through September 19, 1996; and -29 mV, September 19-30, 1996. The near-bottom wiper probe failed in July 1995 and was replaced with an optical sensor without the self-cleaning function on October 12, 1995. The calibration of the near-bottom sensor had a standard error of $13 \mathrm{mg} / \mathrm{L}$ (fig. 35). An autosampler was deployed July 16-18, 1996, to help calibrate the mid-depth and near-bottom sensors. Suspended-solids concentration data collected during water year 1996 are presented in figures 36 and 37. 


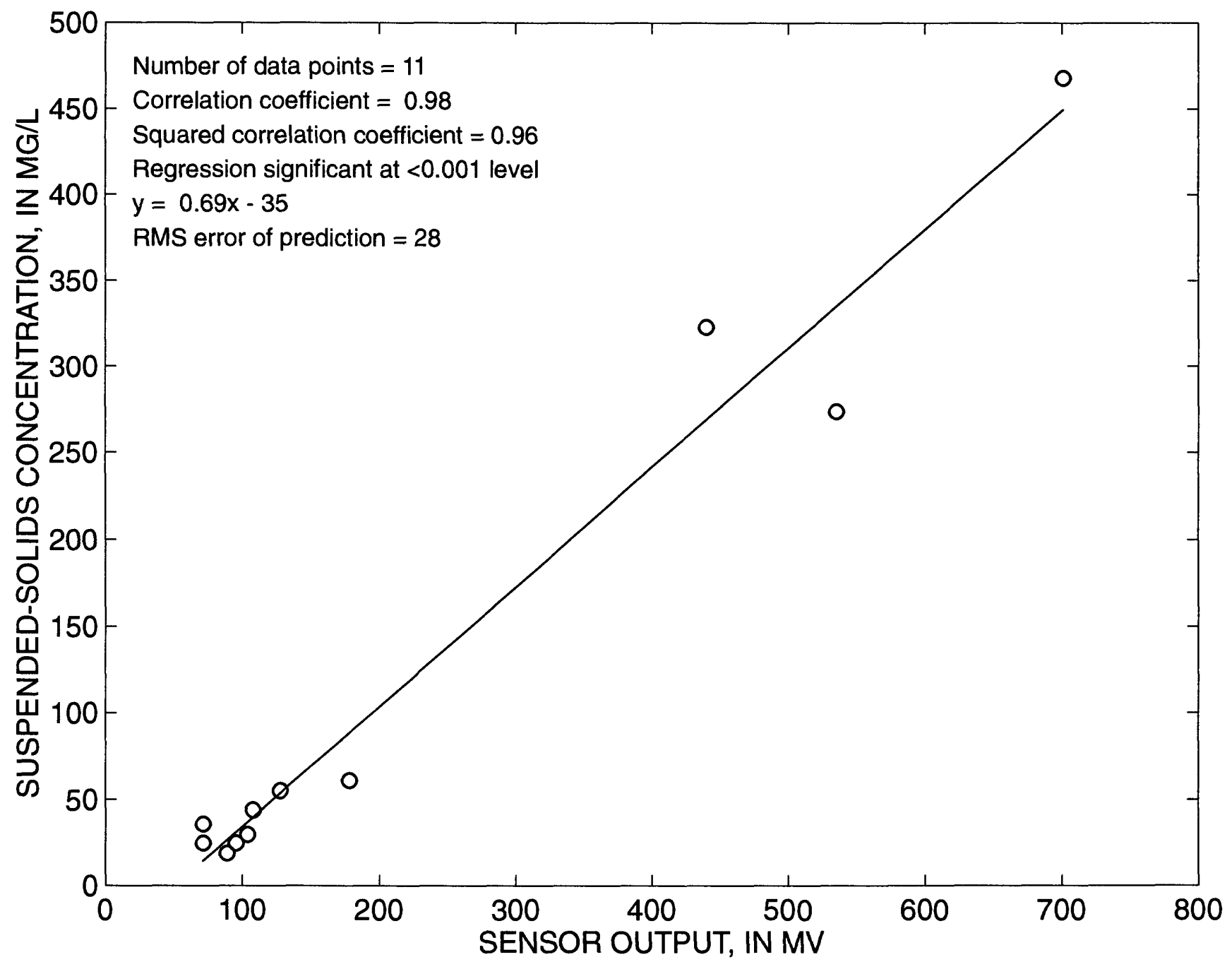

Figure 33. Calibration of mid-depth optical backscatterance sensor at Dumbarton Bridge, South San Francisco Bay, California, October 12 through April 25, water year 1996. 


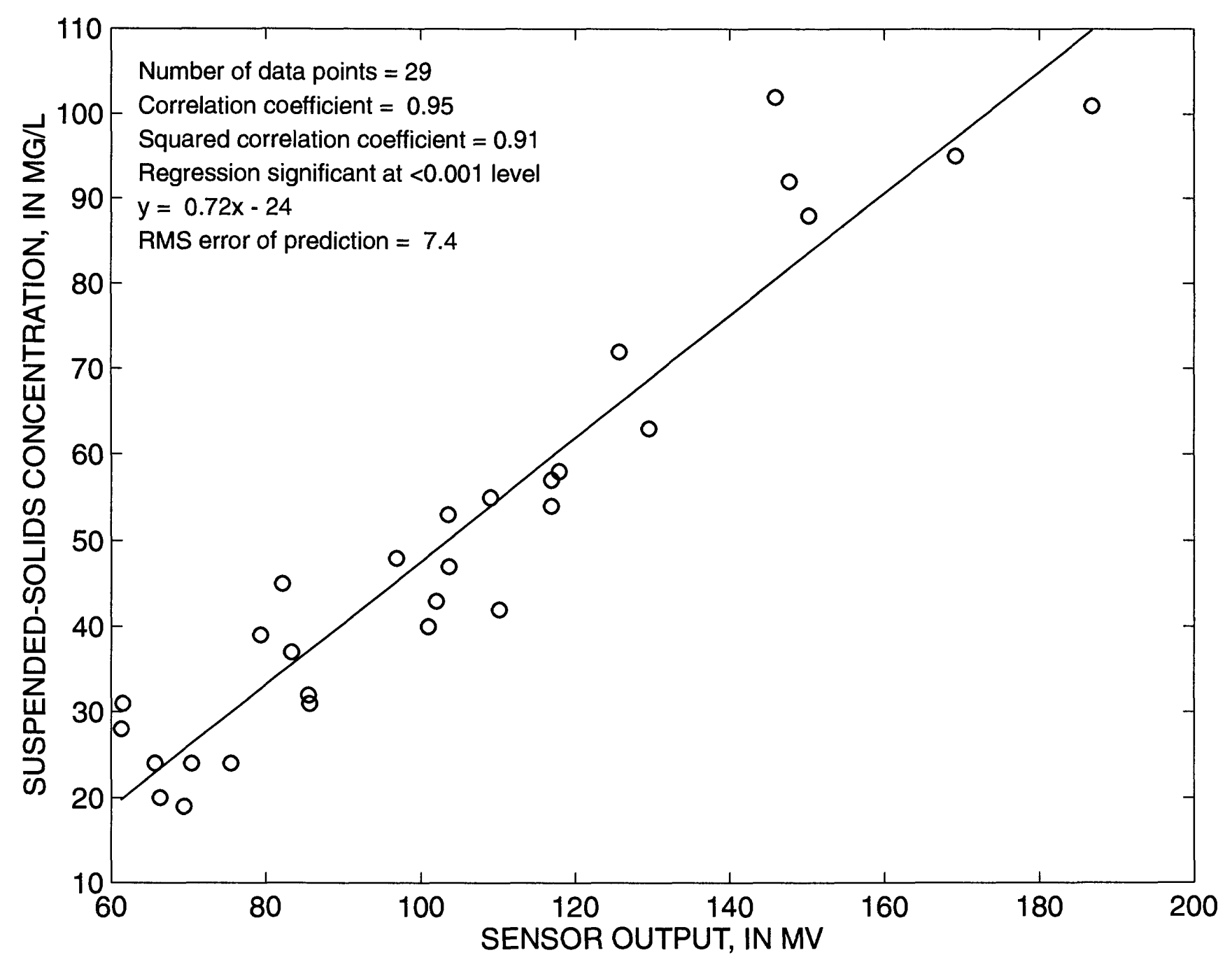

Figure 34. Calibration of mid-depth optical backscatterance sensor at Dumbarton Bridge, South San Francisco Bay, California, June 18 through September 30, water year 1996. 


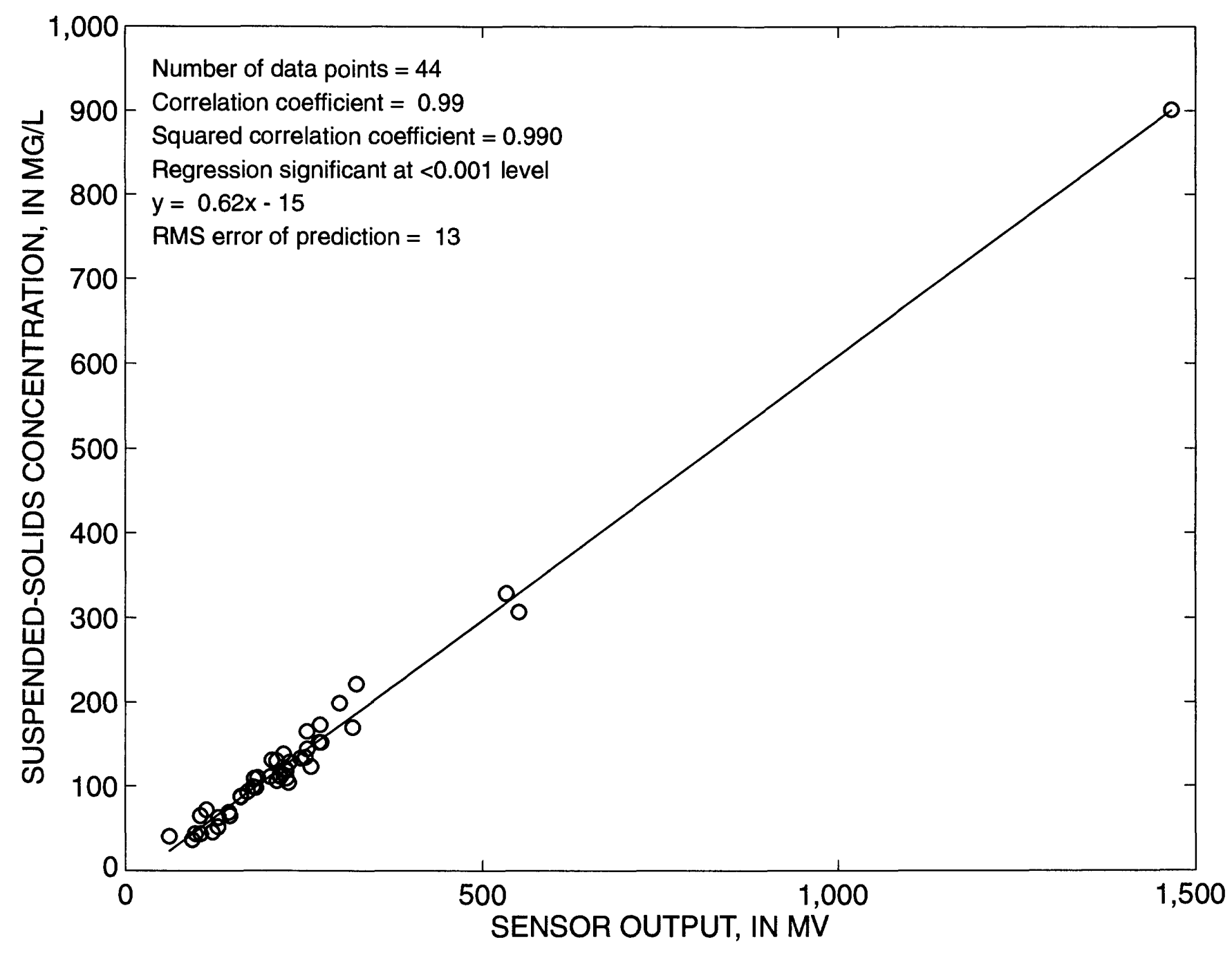

Figure 35. Calibration of near-bottom optical backscatterance sensor at Dumbarton Bridge, South San Francisco Bay, California, water year 1996. 


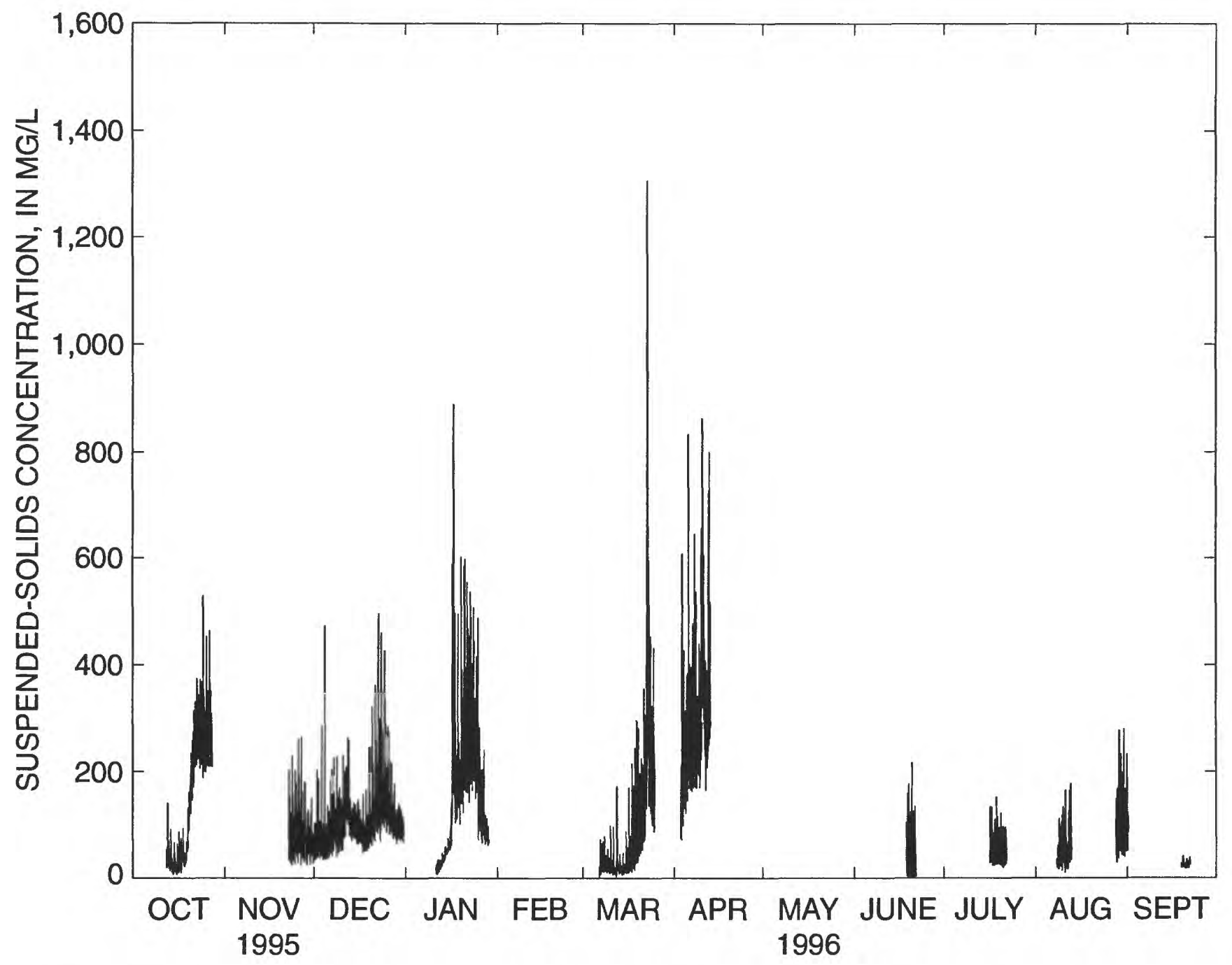

Figure 36. Time series of mid-depth suspended-solids concentration calculated from sensor readings at Dumbarton Bridge, South San Francisco Bay, California, water year 1996. 


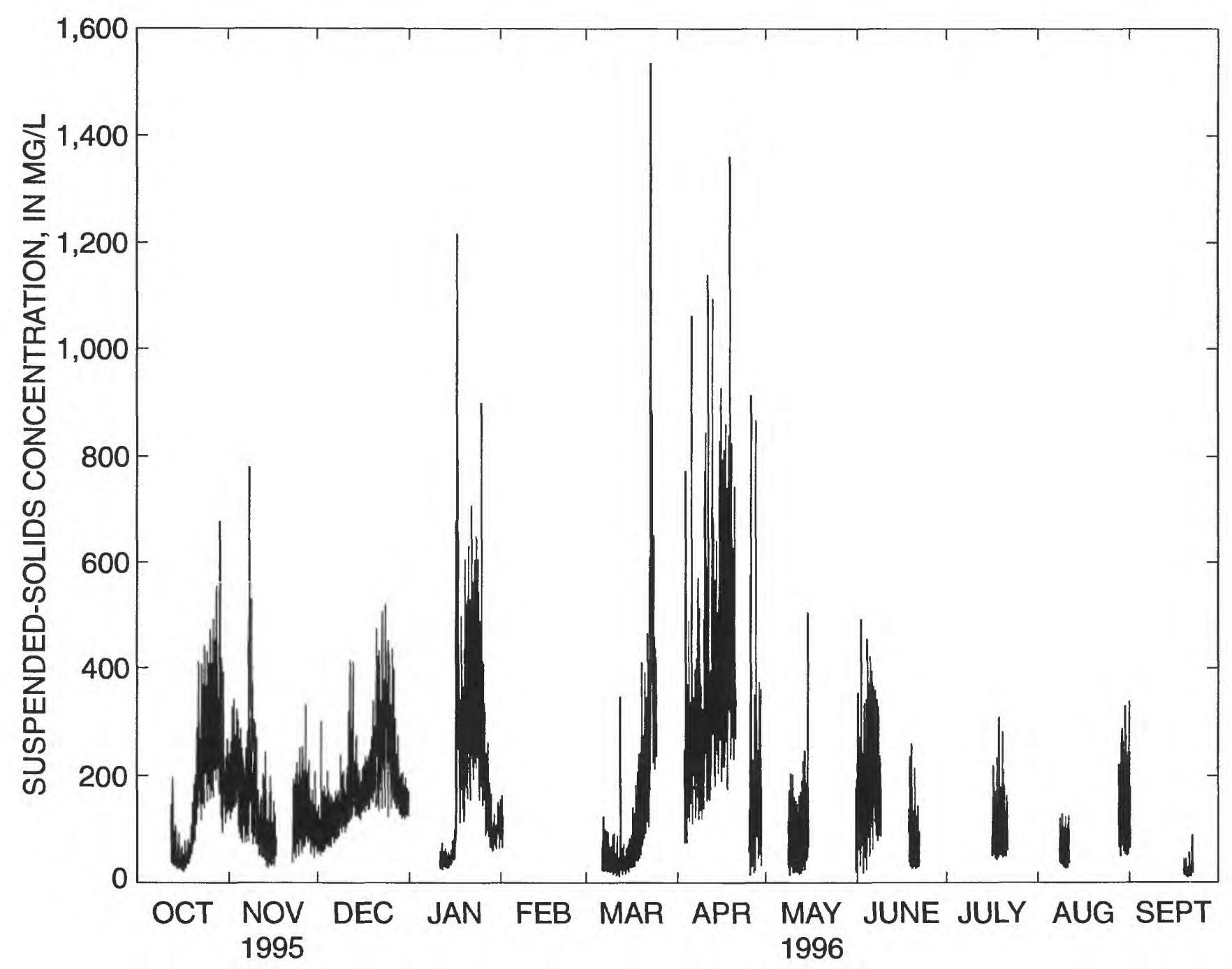

Figure 37, Time series of near-bottom suspended-solids concentration calculated from sensor readings at Dumbarton Bridge, South San Francisco Bay, California, water year 1996. 


\section{San Mateo Bridge}

The mid-depth self-cleaning probe failed in late August 1995 and was replaced with an optical sensor without the self-cleaning function on November 9, 1995, but problems with the data logger resulted in lost data until January 11, 1996. The mid-depth sensor failed on January 26,1996 , and the samples collected were insufficient to develop a calibration curve. The middepth sensor was replaced on March 7, 1996, and also failed before sufficient samples were collected to develop a calibration curve. On April 24, 1996, the sensor was once again replaced, and calibration of the third mid-depth sensor was developed using five samples collected during water year 1996 and four samples collected during water year 1997. The calibration had a standard error of $7.4 \mathrm{mg} / \mathrm{L}$ (fig. 38). A shift of $+110 \mathrm{mV}$, calculated from water-sample data not shown on figure 38, was applied to the mid-depth record for September 18-30, 1996. The nearbottom self-cleaning probe failed in April 1995 and was replaced with an optical sensor without the self-cleaning function on November 9, 1995; however, for the same reason as described for the mid-depth sensor, data were not collected successfully until January 11,1996 . The calibration of the near-bottom sensor had a standard error of $4.8 \mathrm{mg} / \mathrm{L}$ (fig. 39). A shift of -36 $\mathrm{mV}$, based on one water sample not shown on figure 39, was applied to the record for August 28 through September 18, 1996. Suspended-solids concentration data collected during water year 1996 are presented in figures 40 and 41. 


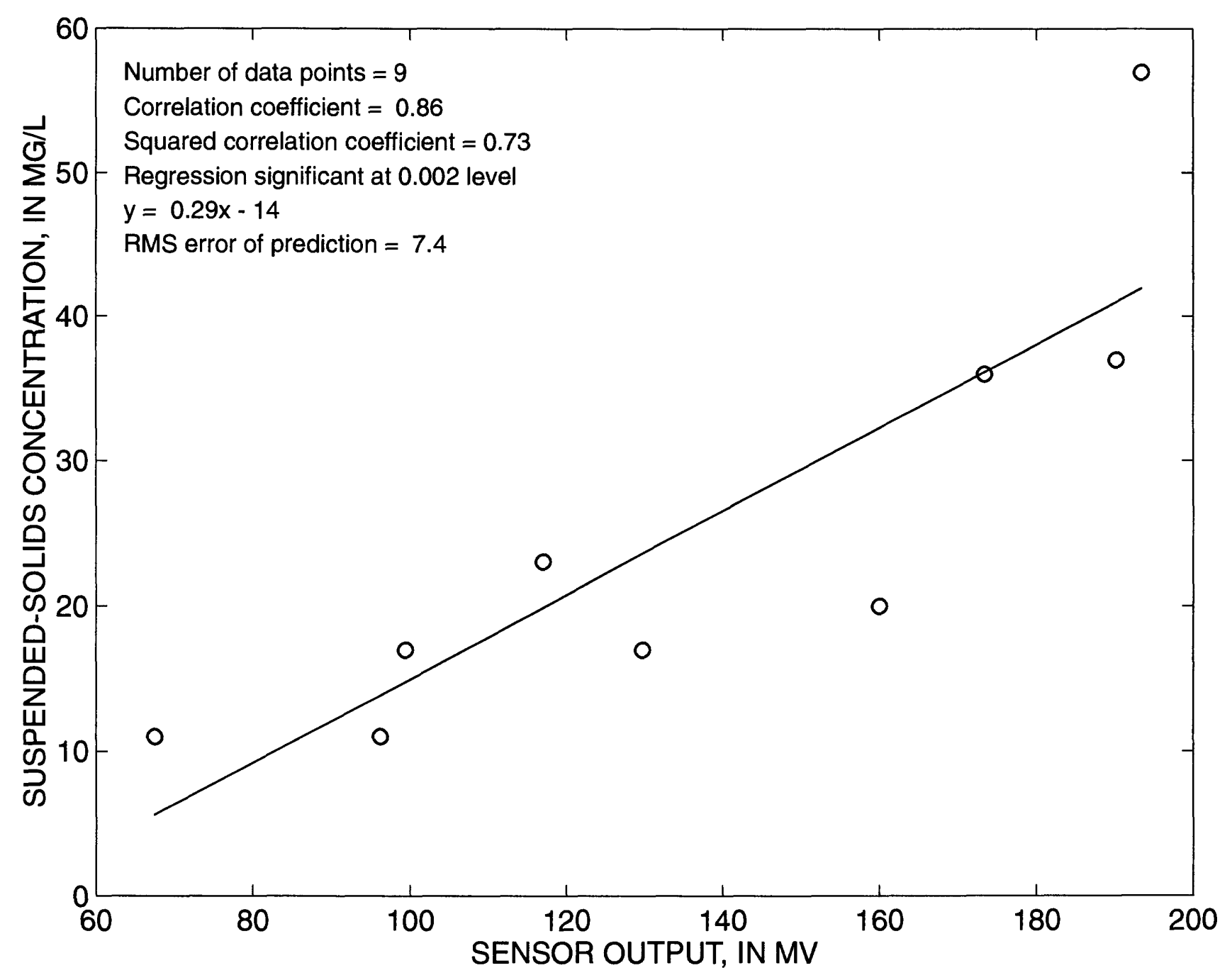

Figure 38. Calibration of mid-depth optical backscatterance sensor at San Mateo Bridge, South San Francisco Bay, California, water year 1996. 


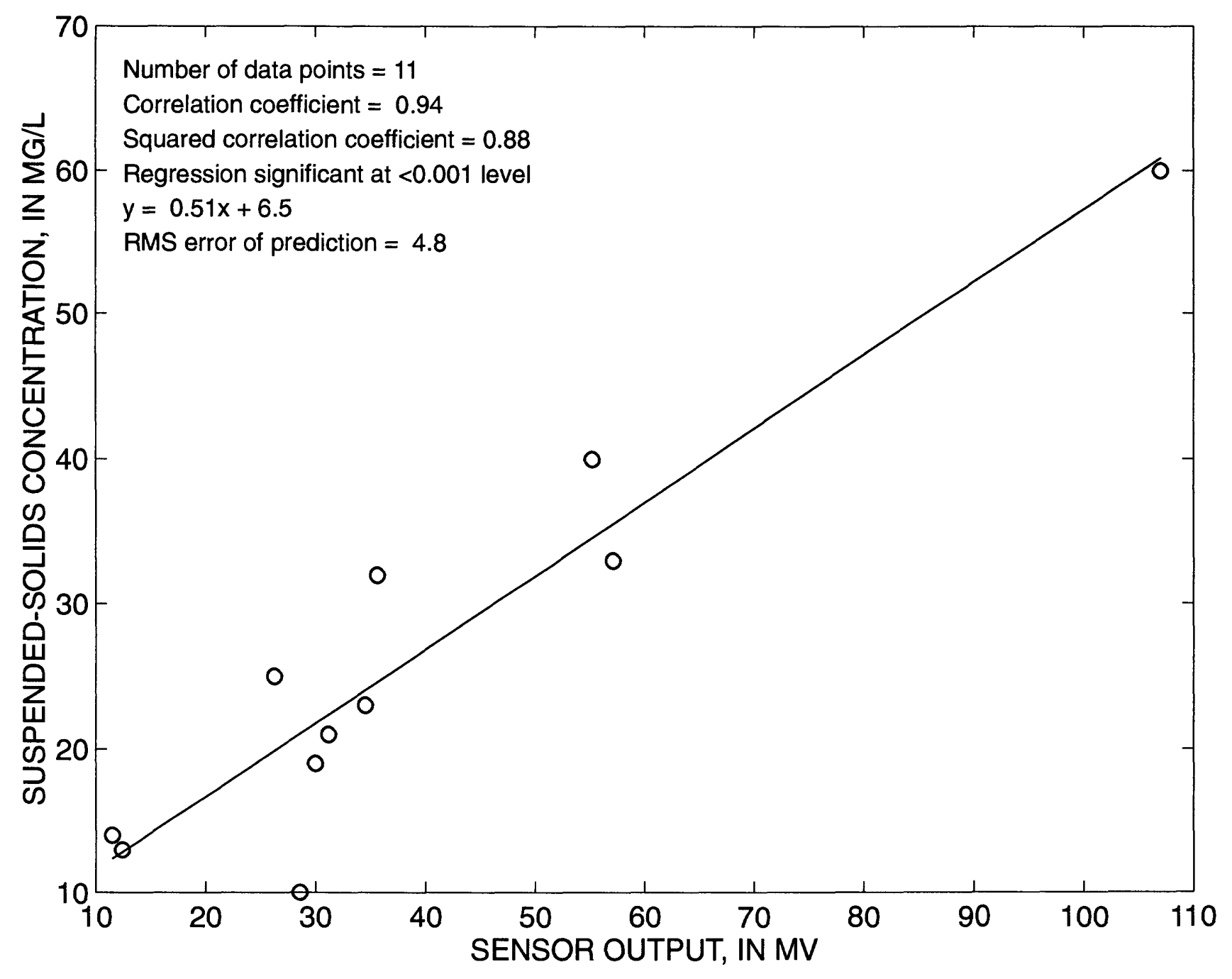

Figure 39. Calibration of near-bottom optical backscatterance sensor at San Mateo Bridge, South San Francisco Bay, California, water year 1996. 


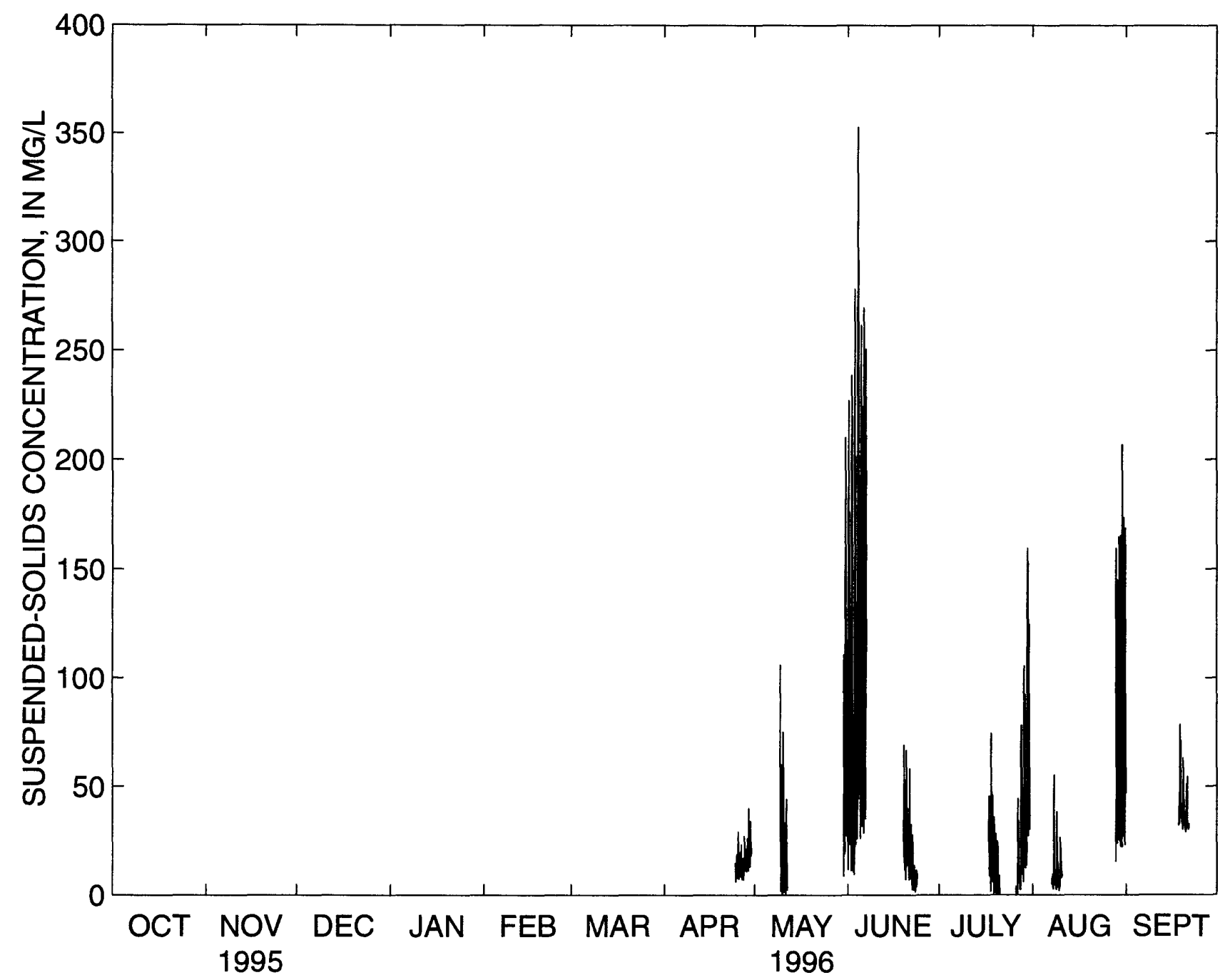

Figure 40. Time series of mid-depth suspended-solids concentration calculated from sensor readings at San Mateo Bridge, South San Francisco Bay, California, water year 1996. 


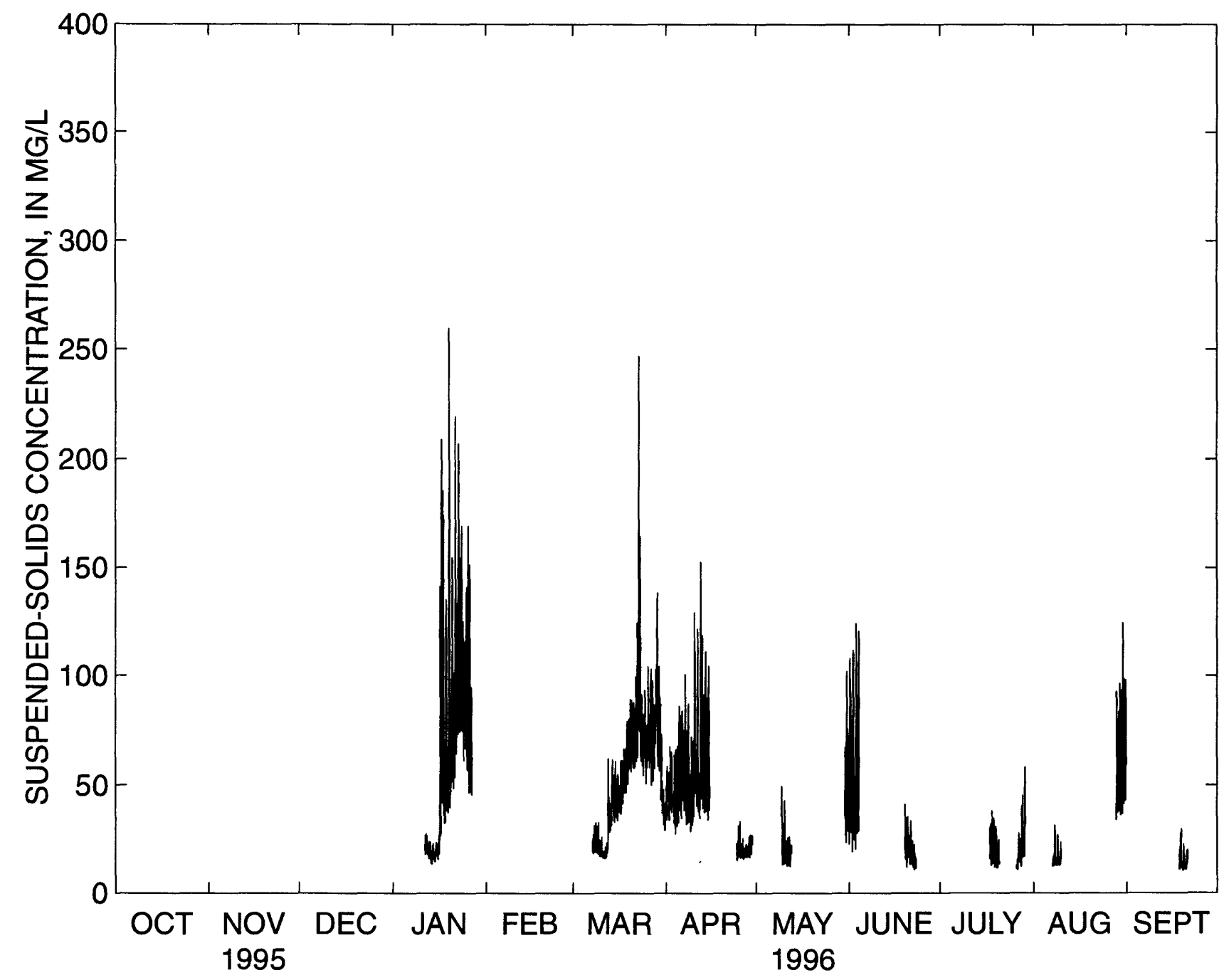

Figure 41. Time series of near-bottom suspended-solids concentration calculated from sensor readings at San Mateo Bridge, South San Francisco Bay, California, water year 1996. 


\section{SUMMARY}

Suspended-solids concentration data were collected by the U.S. Geological Survey (USGS) at three sites in Suisun Bay, three sites in Central San Francisco Bay, and three sites in South San Francisco Bay during water year 1996. Two types of optical backscatterance sensors, controlled by an electronic data logger, were used to monitor suspended solids. Water samples were collected to calibrate the electrical output of the optical sensors to suspended-solids concentration, and the recorded data were recovered and edited. Biological growth can foul optical sensors, and about 30 percent of the data was invalidated by fouling. Data are available from the files of the USGS in Sacramento, California.

\section{REFERENCES}

Arthur, J.F., and Ball, M.D., 1979, Factors influencing the entrapment of suspended material in the San Francisco Bay-Delta Estuary, in Conomos, T.J., ed., San Francisco Bay: The urbanized estuary: San Francisco, Pacific Division of the American Association for the Advancement of Science, p. 143-174.

Brown, C.L., and Luoma, S.N., 1995, Use of the euryhaline bivalve Potamocorbula amurensis as a biosentinal species to assess trace metal contamination in San Francisco Bay: Marine Ecology Progress Series, v. 124, p. 129-142.

Buchanan, P.A., and Schoellhamer, D.H., 1995, Summary of suspended-solids concentration data, Central and South San Francisco Bays, California, water years 1992 and 1993:

U.S. Geological Survey Open-File Report 94-543, 15 p.

- 1996, Summary of suspended-solids concentration data, San Francisco Bay, California, water year 1995: U.S. Geological Survey Open-File Report 96-591, 40 p.

Buchanan, P.A., Schoellhamer, D.H., and Sheipline, R.C., 1996, Summary of suspended-solids concentration data, San Francisco Bay, California, water year 1994: U.S. Geological Survey Open-File Report 95-776, 48 p.

Carlson, P.R., and McCulloch, D.S., 1974, Aerial observations of suspended-sediment plumes in San Francisco Bay and adjacent Pacific Ocean: U.S. Geological Survey Water-Resources Research, v. 2, no. 5, p. 519-526.

Cloern, J.E., 1987, Turbidity as a control on phytoplankton biomass and productivity in estuaries: Continental Shelf Research, v. 7, no. 11/12, p. 1367-1381.

Cole, B.E., and Cloern, J.E., 1987, An empirical model for estimating phytoplankton productivity in estuaries: Marine Ecology Progress Series, v. 36, p. 299-305.

Conomos, T.J., and Peterson, D.H., 1977, Suspended-particle transport and circulation in San Francisco Bay, an overview: New York, Academic Press. Estuarine Processes, v. 2, p. 82-97.

Domagalski, J.L., and Kuivila, K.M., 1993, Distributions of pesticides and organic contaminants between water and suspended sediment, San Francisco Bay, California: Estuaries, v. 16, no. 3 A, p. $416-426$.

Downing, J.P., 1983, An optical instrument for monitoring suspended particulates in ocean and laboratory: in OCEANS 1983, San Francisco, California, August 29-September 1, 1983, Proceedings: p. 199-202. 
Downing, J.P., Sternburg, R.W., and Lister, C.R.B., 1981, New instrumentation for the investigation of sediment suspension processes in the shallow marine environment: Marine Geology, v. 42, p. 19-34.

Fishman, M.J., and Friedman, L.C., 1989, Methods for determination of inorganic substances in water and fluvial sediments: U.S. Geological Survey Techniques of Water-Resources Investigations, book 5, chap. A1, $545 \mathrm{p}$.

Hammond, D.E., Fuller, C., Harmon, D., Hartman, B., Korosec, M., Miller, L.G., Rea, R., Warren, S., Berelson, W., and Hager, S.W., 1985, Benthic fluxes in San Francisco Bay: Hydrobiologia, v. 129, p. 69-90.

Jassby, A.D., and Powell, T.M., 1994, Hydrodynamic influences on interannual chlorophyll variability in an estuary: Upper San Francisco Bay-Delta (California, U.S.A.): Estuarine, Coastal and Shelf Science, v. 39, p. 595-618.

Kimmerer, Wim, 1992, An evaluation of existing data in the entrapment zone of the San Francisco Bay Estuary: Tiburon, California, Biosystems Analysis, Inc., Technical Report 33, $49 \mathrm{p}$.

Kuwabara, J.S., Chang, C.C.Y., Cloern, J.E., Fries, T.L., Davis, J.A., and Luoma, S.N., 1989, Trace metal associations in the water column of South San Francisco Bay, California: Estuarine, Coastal and Shelf Science, v. 28, p. 307-325.

Lacy, J.R., Schoellhamer, D.H., and Burau, J.R., 1996, Suspended-solids flux at a shallow-water site in South San Francisco Bay, California, in Bathala, C.T., ed., North American Water and Environment Congress, Anaheim, Calif., June 23-28, 1996, Proceedings: New York, American Society of Civil Engineers.

Levesque, V.A., and Schoellhamer, D.H., 1995, Summary of sediment resuspension monitoring, Old Tampa Bay and Hillsborough Bay, Florida, 1988-91: U.S. Geological Survey WaterResources Investigations Report 94-4081, 31 p.

Luoma, S.N., Cain, D., and Johansson, C., 1985, Temporal fluctuations of silver, copper, and zinc in the bivalve Macoma balthica at five stations in South San Francisco Bay: Hydrobiologia, v. 129, p. 109-120.

Peterson, D.H., Conomos, T.J., Broenkow, W.W., and Doherty, P.C., 1975, Location of the non-tidal current null zone in northern San Francisco Bay: Estuarine and Coastal Marine Science, v. 3, p. 1-11.

Porterfield, George, 1980, Sediment transport of streams tributary to San Francisco, San Pablo, and Suisun Bays, California, 1909-1966: U.S. Geological Survey Water-Resources Investigations Report 80-64, 91 p.

Powell, T.M., Cloern, J.E., and Huzzey, L.M., 1989, Spatial and temporal variability in South San Francisco Bay (U.S.A.). I. Horizontal distributions of salinity, suspended sediments, and phytoplankton biomass and productivity: Estuarine, Coastal and Shelf Science, v. 28, p. 583-597.

Schoellhamer, D. H., 1996, Factors affecting suspended-solids concentrations in South San Francisco Bay, California: Journal of Geophysical Research, v. 101, no. C5, p. 12087-12095.

1997, Time series of trace-element concentrations calculated from the series of suspended-solids concentrations and RMP water samples: 1995 Annual Report of the Regional Monitoring Program for Trace Substances, p. 53-55. 
Smith, L.H., 1987, A review of circulation and mixing studies of San Francisco Bay, California: U.S. Geological Survey Circular 1015, 38 p.

Tobin, Ann, Schoellhamer, D.H., and Burau, J.R., 1995, Suspended-solids flux in Suisun Bay, California, in First International Conference of Water Resources Engineering, San Antonio Texas, August 14-18, 1995, Proceedings: New York, American Society of Civil Engineers, p. 1511-1515.

U.S. Environmental Protection Agency, 1992, State of the estuary: Dredging and waterway modification: U.S. Environmental Protection Agency San Francisco Estuary Project, chap. 8, p. 191-215. 